\title{
DÜBLIN
}

Technological University Dublin

ARROW@TU Dublin

\section{Targeting the folate receptor: Improving efficacy in inorganic medicinal chemistry}

\author{
Pauraic McCarron \\ Technological University Dublin, pauraic.mccarron@tudublin.ie \\ Aisling Crowley \\ Technological University Dublin, aisling.crowley@tudublin.ie \\ Denis O'Shea \\ Technological University Dublin, denis.oshea@tudublin.ie
}

See next page for additional authors

Follow this and additional works at: https://arrow.tudublin.ie/schfsehart

Part of the Food Chemistry Commons, Medicinal-Pharmaceutical Chemistry Commons, and the Medicine and Health Sciences Commons

\section{Recommended Citation}

Mc Carron, Pauraic \& Crowley, Aisling \& Shea, Denis \& Mccann, Malachy \& Howe, Orla \& Hunt, Mary \& Devereux, Michael. (2018). Targeting the Folate Receptor: Improving Efficacy in Inorganic Medicinal Chemistry. Current Medicinal Chemistry. 25. 10.2174/0929867325666180209143715.

This Article is brought to you for free and open access by the School of Food Science and Environmental Health at ARROW@TU Dublin. It has been accepted for inclusion in Articles by an authorized administrator of ARROW@TU Dublin. For more information, please contact arrow.admin@tudublin.ie, aisling.coyne@tudublin.ie, gerard.connolly@tudublin.ie.

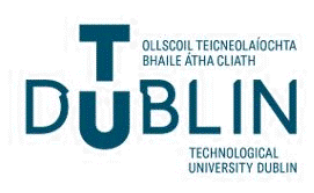


Authors

Pauraic McCarron, Aisling Crowley, Denis O'Shea, Malachy McCann, Orla L. Howe, Mary Hunt, and Michael Devereux 
See discussions, stats, and author profiles for this publication at: https://www.researchgate.net/publication/323091246

\section{Targeting the Folate Receptor: Improving Efficacy in Inorganic Medicinal Chemistry}

Article in Current Medicinal Chemistry · February 2018

DOI: $10.2174 / 0929867325666180209143715$

CITATIONS

27

7 authors, including:

Pauraic Mc Carron

Technological University Dublin - Tallaght Campus

13 PUBLICATIONS 237 CITATIONS

SEE PROFILE

Denis O Shea

Technological University Dublin - City Campus

17 PUBLICATIONS 879 CITATIONS

SEE PROFILE

Some of the authors of this publication are also working on these related projects:

Project Phenanthroline based Transition Metal Complexes with Antibacterial Activity View project

Project Solar-Thermal and Hybrid Photovoltaic-Thermal Applications View project
READS

1,483

Aisling Crowley

Technological University Dublin - City Campus

1 PUBLICATION 27 CITATIONS

SEE PROFILE

Malachy Mccann

13. National University of Ireland, Maynooth

171 PUBLICATIONS 5,674 CITATIONS

SEE PROFILE 


\title{
Targeting the folate receptor: improving efficacy in inorganic medicinal chemistry.
}

\author{
Pauraic Mc Carron ${ }^{1}$, Aisling Crowley ${ }^{1,2}$, Denis O’Shea ${ }^{1,3}$, Malachy McCann", Orla Howe ${ }^{1,2}$, Mary \\ Hunt $^{1,2}$ and Michael Devereux ${ }^{1 *}$
}

\footnotetext{
${ }^{1}$ The Centre for Biomimetic \& Therapeutic Research, Focas Research Institute, Dublin Institute of Technology, Camden Row, Dublin 8, Ireland

${ }^{2}$ School of Biological Sciences, Dublin Institute of Technology, Kevin St., Dublin 8, Ireland

${ }^{3}$ School of Food Science \& Environmental Health, Dublin Institute of Technology, Cathal Brugha St., Dublin 1, Ireland

${ }^{4}$ Chemistry Department, Maynooth University, National University of Ireland, Maynooth, Co. Kildare, Ireland
}

\footnotetext{
* Address correspondence to this author at the College of Sciences and Health, Dublin Institute of Technology, Kevin Street, Dublin 8, Ireland; Tel: +353 1 4024585; Fax: +353 1402 4998; e-mail: michael.devereux@dit.ie.
} 


\begin{abstract}
The discovery of the high-affinity, high-specificity folate receptor in mamalian kidney cells, coupled with the ability of folate to enter cells by folate receptor-mediated endocytosis and the subsequent elucidation of the folate receptor's overexpression in specific cancer cell types; heralded the arrival of the area of chemotherapeutic folate targeting. The application of purely organic folate-based small-molecule drug conjugates that selectively target the folate receptor, which is over expressed in several diseases such as cancer, is well established. The application of inorganic folate-targeted drugs offers significant potential to expand and enhance this therapeutic approach. From the data made available to date, it is apparent that this aspect of inorganic medicinal chemistry is in its youth but has the capability to contribute greatly to cancer research, both in therapy and diagnosis. The union of folate-receptor targeting and inorganic medicine may also lead to the development of treatments for disorders such as chronic-inflammation, tuberculosis, neurodegenerative disease and leishmaniasis. In this review, we summarize what is known about the coordination chemistry of folic acid and the therapeutic potential of such complexes. We also describe approaches adopted to conjugate platinum drugs to folate- or folate-carrier- systems and their prospective ability to overcome problems associated with unwanted side-effects and resistance by improving their delivery and/or selectivity. The literature pertaining to non-platinum metal complex conjugates with folic acid is also reviewed revealing that this is an area that offers significant potential to develop targeted therapeutic approaches in areas such as chemotherapy and molecular imaging for diagnostics.
\end{abstract}

Keywords: metal-folate complexes, folate receptor-targeted drug delivery, chemotherapeutics, diagnostics. 


\section{INTRODUCTION}

The origins of folate receptor-targeted chemotherapy can be traced back to 1947; that year Sidney Farber building upon earlier observations made by Louis S Goodman and Alfred Gilman on the effects of alkylating agents (mustine) on white blood cells and lymph nodes demonstrated that 4-aminopteroyl-glutamic acid (aminopterin), a synthetic derivative of the B-vitamin folic acid, resulted in remissions in children with acute leukemia.[1-5] Aminopterin functions by competing with folate for the binding site of the dihydrofolate reductase (DHFR) enzyme hence blocking the uptake of folic acid and consequently arresting DNA replication.[6-8] Aminopterin was later superseded with the advent of methotrexate, an antifolate drug still widely used today, the first drug shown to cure a metastatic tumor of choriocarcinoma.[9] The success of these initial chemotherapeutics encouraged chemists to seek new molecules that could inhibit cell replication entirely - The era of cancer chemotherapy had begun.

The paragon of chemotherapy is the "targeting" or site-specific recognition of cancerous tissue by a therapeutic agent, the proposed ability of such an agent to discern and bind to a unique aspect of cancerous tissue and then preferentially deliver a precise cytotoxic effect, is a highly desirable attribute. Many examples of the effective use of this strategy can be found in the literature, including targeted therapies in advanced stages of development and a small number in clinical use.[10-14] Each type of the proposed targeted chemotherapy utilises a specific molecular target and the area can be broadly subcategorised into those which employ either cell-surface carbohydrates (carbohydrate targeting), cellular antigens for antibodies (antibody targeting) or cell surface receptors (receptor targeting).[15] There are numerous folate receptor targeted therapies currently in various stages of development. Vintafolide is one such folate receptor targeted therapy, it is a small molecule drug conjugate (SMDC), development of which was halted in Phase III due to poor efficacy on the pre-specified outcome of Progression-Free Survival (PFS).[16, 17] Other examples of folate receptor targeted therapies in development are the monoclonal antibody farletuzumab, and the antibody-drug conjugate IMGN853.[18-21]

Given the numerous targeted therapeutic methodologies currently under development, this review will focus specifically on those utilizing the folate moiety to selectivity target the folate receptor (FR) which is over expressed on many malignant cell types.[22-33] Furthermore, activated macrophages, also exhibit highly elevated FR expression; this may also provide a means of preferential targeting of Mycobacterium-infected macrophages and activated macrophages in inflammatory and autoimmune diseases (rheumatoid, inflammatory and osteoarthritis), whilst folate targeted conjugates may also hold promise as antileishmanial agents.[34-50]

\subsection{Folic acid: structure, function and its role in disease progression}

Folic acid (FA) is a member of the family of B9 vitamins, its molecular structure can be subdivided into three components which consist of a pteridine moiety with A and B rings, linked by a methylene bridge at carbon 6 to paraaminobenzoic acid (PABA), with an amide bond to a glutamic acid moiety (Fig. 1).[51] 

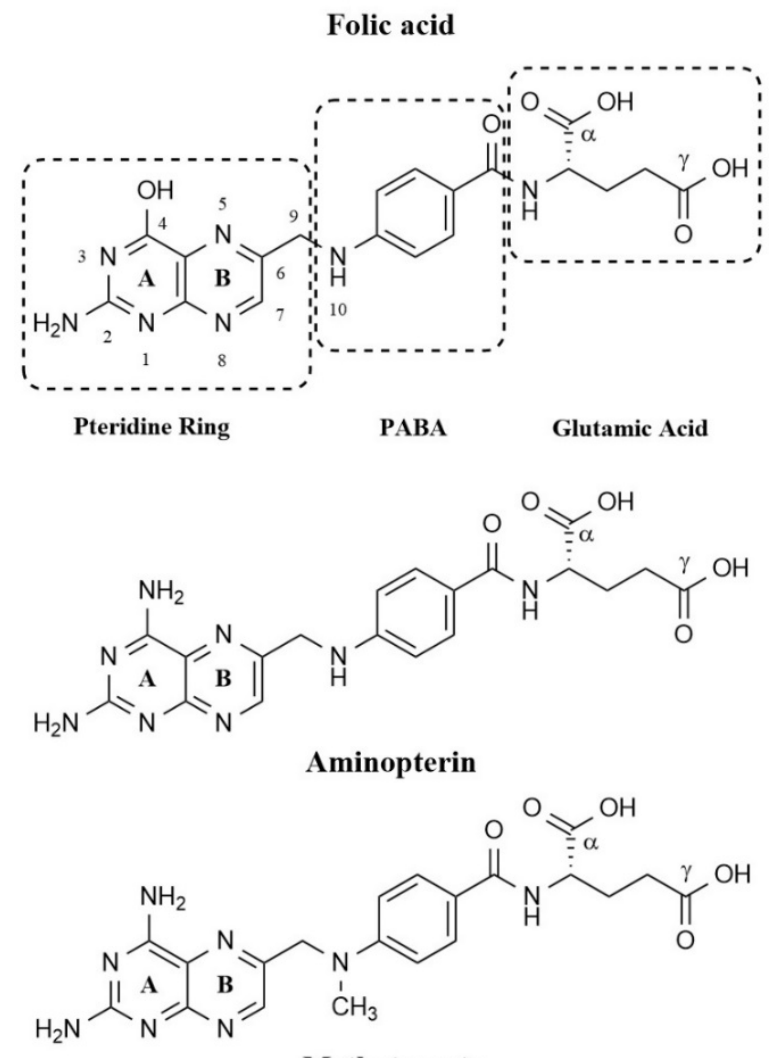

Fig. 1. The structure of folic acid highlighting the three central components; the pteridine ring, para-aminobenzoic acid (PABA) and the glutamate moiety, atom number also shown for reference. Structure of aminopterin the first synthetic antifolate agent and methotrexate (MTX) a chemotherapeutic agent developed in 1948 and still in clinical use today.

The terms 'folate' and folic acid are often used interchangeably but it should be noted that folic acid as depicted in Figure $\mathbf{1}$ is a pharmacological agent and does not occur in nature.[51] 'Folate' is a generic term used to refer to a number of members of the B9 vitamin family.[52] For the purposes of this review we will refer to folate (i.e. the deprotonated form of folic acid) and folic acid interchangeably unless otherwise stated. Folic acid is the form used in vitamin supplement tablets and in cell culture media due to its chemical stability, but within cells it is first reduced to dihydrofolate (DHF) and then to tetrahydrofolate (THF) (Fig. 2).[51] 


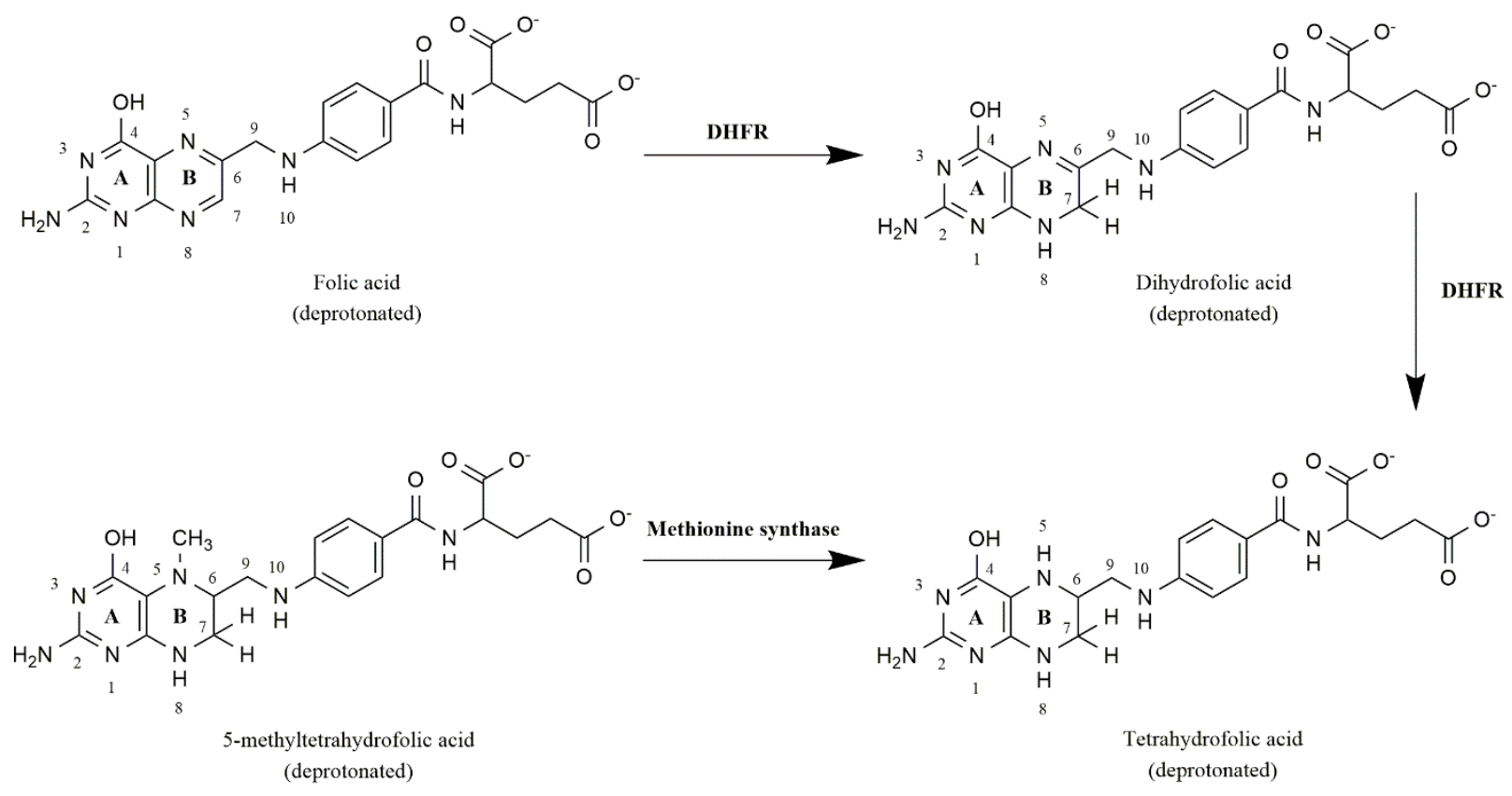

Fig. 2. Folic acid is reduced to dihydrofolic acid (DFA), which is in turn reduced to tetrahydrofolic acid (TFA) in reactions catalysed by dihydrofolate reductase (DHFR). 5-Methyltetrahydrofolic acid (5-methylTHF) is the major folate found in blood.[51]

Endogenous folic acid is not found in human cells and is derived entirely from dietary sources with 5methyltetrahydrofolic acid (5-methylTHF) (Fig. 2) being the major folate derived from dietary sources and the dominant folate found in the blood of humans and rodents.[51]

In 1948, antifolate agents such as aminopterin (Fig. 1) were found to be the first agents to induce temporary remission when administered to children with acute lymphoblastic leukemia.[3] In later years others demonstrated that the use of methotrexate (MTX) against solid tumors which were much more effective than in leukemia, achieving complete remission in breast cancer, choriocarcinoma, chorioadenoma and mycosis fungoides a form of cutaneous Tcell lymphoma.[9, 53-55] MTX supplanted aminopterin in the clinic during the 1950s due to its reported superior therapeutic index, although this apparent superior therapeutic capability of MTX over that of aminopterin has recently become the subject of further investigation [56-60] As is clearly evident in Figure 1, folic acid, aminopterin and MTX are structurally similar, with aminopterin differing from folic acid only in the substitution of an amino for a hydroxyl group at the N4-position of the pteridine ring. MTX in comparison to aminopterin possess an addition methyl group at the N10 position, in the bridge between the pteridine and p-amino-benzoic acid moieties.[61] Initially little was known about the biochemical and molecular pharmacology of MTX and its exact mode of action which hampered efforts to synthesise new structurally related antifolate derivatives.[62] Pemetrexed, the second antifolate, was approved in 2004 more than fifty years after MTX and is an effective treatment for malignant pleural mesothelioma and non-small cell lung cancer.[63-66] In addition, a new generation of antifolates or folate antimetabolites are under 
investigation or in clinical use, some of which are dihydrofolate reductase (DHFR) inhibitors such as Talotrexin which has a higher binding affinity for DHFR than MTX and other examples such as Raltitrexed, Lometrexol and ONX0801 (Phase 1 trials) inhibit other crucial enzymes in the folate metabolism pathway.[58, 67-72]

\subsection{Folate uptake into cells and tissues}

The cellular uptake of folate is mediated by three distinct transporters; the reduced folate carrier (RFC), proton coupled folate transporter (PCFT) and the folate receptor (FR). A review by Zhao et al details the structure and function of the RFC and the PCFT.[73] The RFC, is the predominant folate transporter expressed in normal adult tissue and is ubiquitously expressed in the intestine, hepatocytes, choroid plexus and renal epithelial cells, in addition it facilitates transplacental transport of folates and folate transport across the blood-brain barrier.[74-77] It is a transmembrane anion exchanger with a $K_{m}$ for 5-methylTHF, 5-formylTHF in the range of 3-7 $\mu \mathrm{M}$ and a very low affinity for folic acid (Ki approx. 150-200 $\mu \mathrm{M}$ ).[73] The PCFT is the main transporter of folate in lower $\mathrm{pH}$ environments, such as the intestine.[78]

The folate receptor (FR) is a glycopolypeptide with high affinity for binding and transporting physiological concentrations of folate into cells. The human FR family comprises of four isoforms $-\alpha,-\beta,-\gamma$ and $-\delta$. Of the four, only FR $\alpha$ and FR $\beta$ are glycosylphosphatidylinositol (GPI)-linked, or membrane bound proteins while the third, FR $\gamma$ is a constitutively expressed secretory protein. The fourth isoform, FR $\delta$, has been identified only from genome database mining but tissue expression and functionality have not been determined.[79] FR $\alpha$ is a cysteine rich GPIlinked membrane protein which is expressed at high levels in various epithelial cancers of the mammary gland, ovary, prostate, brain, nose and throat.[80, 81] It exhibits a high affinity $\left(K_{d}<10^{-9} M\right)$ for folic acid, a binding affinity $~ 10$ times greater than any other reduced form of the vitamin or the anti-folate drug, methotrexate.[33] Furthermore, it has been reported that in epithelial ovarian cancer, the histological grade and stage of tumour progression correlates strongly with FR $\alpha$ expression and consequently that FR $\alpha$ expression is associated with parameters of biological aggressiveness in ovarian cancers.[82, 83] The expression of the FR- $\alpha$ may also hold potential as both a therapeutic and prognostic target in a number of different cancers, especially ovarian, colorectal and breast cancer.[27, 84, 85] High level expression of FR $\alpha$ is significantly associated with triple negative/basal tumors and a correlation has been found between intense overexpression of FR $\alpha$ and poor prognosis in patients presenting with triple negative breast cancer.[27] In instances of lung cancer which is the leading cause of cancer death worldwide, Non-small-cell lung cancer (NSCLC) accounts for $80 \%$ of lung cancers and has been shown to express FR $\alpha$ to a high extent.[29, 86, 87]

The physiological process by which both dietary folate and folate-drug conjugates enter FR+ cells is known as endocytosis. It involves the binding of an exogenous folate-drug conjugate to membrane bound FRs and the immediate invagination of the plasma membrane around the receptor-ligand complex to form an intracellular vesicle or endosome. This vesicle acidifies to $\sim \mathrm{pH} 5$ through the action of proton pumps, inducing a conformational change 
in the receptor and the release of the active drug from the folate delivery system (Fig. 3).[88] However, the precise pathway(s) have not yet been elucidated and are still widely discussed.[89-92] The work of Wibowo et al strongly suggested that the $\mathrm{pH}$ of the environment plays a major role in the structural rearrangement of the FR, with the folate binding cleft being in an open conformation at neutral $\mathrm{pH}$ and blocked at the acidic $\mathrm{pH}$ of the endosome.[93] Receptormediated endocytosis offers an advantage as it is non-destructive to the folate-drug conjugate and, as the folate receptor is known to recycle regularly between the cytosol and cell surface, an increased drug concentration can be obtained within the cell.[78, 94] Given the restricted expression of FR isoforms (particularly FR $\alpha$ ) on malignant tissue, in addition to its high affinity for folic acid, folate-mediated drug delivery is clearly advantageous to overcoming unwanted drug toxicity as well as offering the benefit of increased drug concentration in target cells.

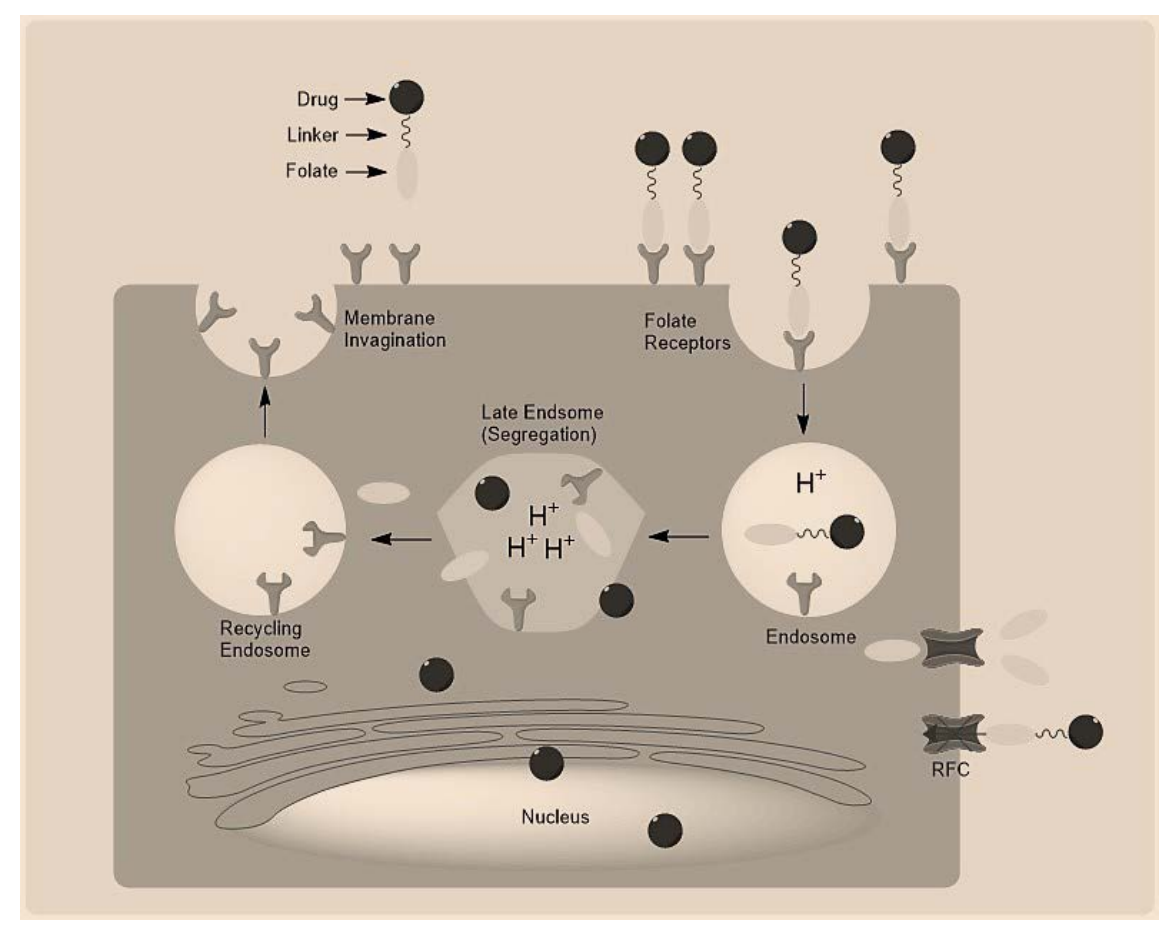

Fig. 3. Folate receptor-mediated endocytosis of folate-drug conjugates. The folate-drug conjugate is taken up into cells by binding of folate to the folate receptor. Invagination of the plasma membrane results in receptor mediated endocytosis. The acidic $\mathrm{pH}(\sim 5)$ results in dissociation of the drug cargo and the folate receptor is recycled to the cell surface once more (modified from Leamon et al).[88] RFC: reduced folate carrier.

The application of FR-targeted molecules is not new; there have been many articles and papers published regarding the conjugation of folates to known organic drug molecules such as taxol, paclitaxel and doxorubicin to improve drug targeting.[95-97] In addition, the application of folates conjugated to fluorescent molecules as luminescent probes to detect FR+ tumours is well established due to folic acid's dual targeting and fluorescent properties.[98] The advantageous chemotherapeutic potential of folate-targeted inorganic nanoparticles such as mesoporous materials,[99-103] gold-nanoshells,[104-107] quantum dots (QD),[108-111] and magnetic 
nanoparticles,[112-118] has also been established. Along with these the applications of other folate-targeted nanomaterials including liposomes, micelles, dendrimers, oligonucleotides and carbon nanotubes (CNT), which do not possess metal complexes as the active component, have been reviewed in detail elsewhere.[12, 15, 29, 69]

However, there is a void in the literature regarding the coordination chemistry of folic acid and the conjugation of folic acid to metal based molecules and even less regarding their chemotherapeutic capabilities. A review of the literature returned fewer than thirty relevant articles concerning metal-folate complexes, many of which focus on the synthesis and characterisation of metal-folate complexes but do not further investigate any mechanism of action. The main focus of this review article is the targeted uptake of folate-containing metal complexes or folate-metal complex conjugates via the FR. FR targeting molecular conjugates or small molecule drug conjugates (SMDC) of a purely organic chemical structure will not be discussed in detail but will be referenced where necessary.

\section{FOLATE TARGETED CHEMOTHERAPY}

In 1986, Kamen et al, a group from the University of Texas Southwestern Medical Centre reported that monkey kidney cells (MA104) possess a high-affinity, high-specificity folate receptor whose expression is regulated by the folate content of the cell and suggested that a small molecule such as folate can enter cells by receptor-mediated endocytosis.[119] In the early 1990's Leamon and Low t showed that like the free vitamin, proteins conjugated to folic acid could enter certain cells by high affinity receptor mediated endocytosis with the covalent attachment to folate and forming a folate conjugate, virtually any size macromolecule could be capable of entering the cytoplasm of the folate receptor (FR) bearing cells in an intact state.[120-122]

These discoveries led to the development of the area of chemotherapeutic folate targeting. These covalent folate conjugates can be thought of as "molecular Trojan horses" which can leverage the high affinity/specificity of folate towards the folate receptor.[122] The FR has a low level of expression in healthy tissue but is expressed at high levels in many cancers (breast, ovarian, brain, prostate etc.) in order to meet the folate demand of these rapidly dividing cells. This marked difference in expression of the FR between healthy and cancerous cells is the basis for the selection of the FR as a possible chemotherapeutic molecular target.

The glutamate tail of FA possess $\alpha$ and $\gamma$ carboxylic acid moieties (Figure 1), which have markedly different $\mathrm{pK}_{\mathrm{a}}$ values and hence different reactivities.[123, 124] The formation of folate conjugates was previously based upon the assumption that covalent modification of one or both of the carboxylic acid moieties of FA would not adversely affect the binding strength or affinity of the folate conjugates to the FR. In 1999, Leamon et al, determined that macromolecules attached to folic acid by either an $\alpha$ or $\gamma$ glutamyl linkage could associate with FR bearing cells at virtually identical levels.[125] 
In 2013, Chen et al, successfully resolved the crystal structure of the human FR $\alpha$ in complex with folic acid at $2.8 \AA$ resolution.[80] They reported that there is a structural rationale for the absolute requirement of the pterin group for anchoring folate in the binding pocket of the receptor and for the availability of the glutamate group for conjugation with drugs and imaging reagents, without adversely affecting the interactions between receptor and ligand.[80] In addition, Wibowo et al also published structures of human folate receptors $\alpha$ and $\beta$ and described the molecular basis for human FR in complex with antifolates Alimta, aminopterin and methotrexate.[93] More recently Boss et al (2016), synthesized and compared the in vitro and in vivo properties of three pairs of alpha- and gammaconjugated folic acid derivatives labelled with fluorine-18 (Fig. 4).[126] They observed that all folate derivatives displayed a high binding affinity to the FR-alpha and demonstrated by utilising in vivo PET imaging and biodistribution studies in FR-positive KB tumour-bearing mice that both regioisomers had similar FR-specific tumour uptake. Importantly however, the alpha-regioisomers had significantly lower FR-unspecific liver uptake whilst the gamma-regioisomers displayed 50\% lower kidney uptake compared to alpha-regioisomers. In the case of these F-18based radiofolates the site of conjugation to the glutamyl moiety of folic acid had no effect on their in vitro FR-binding affinity but has significant impact on their in vivo biodistribution and uptake.[126]
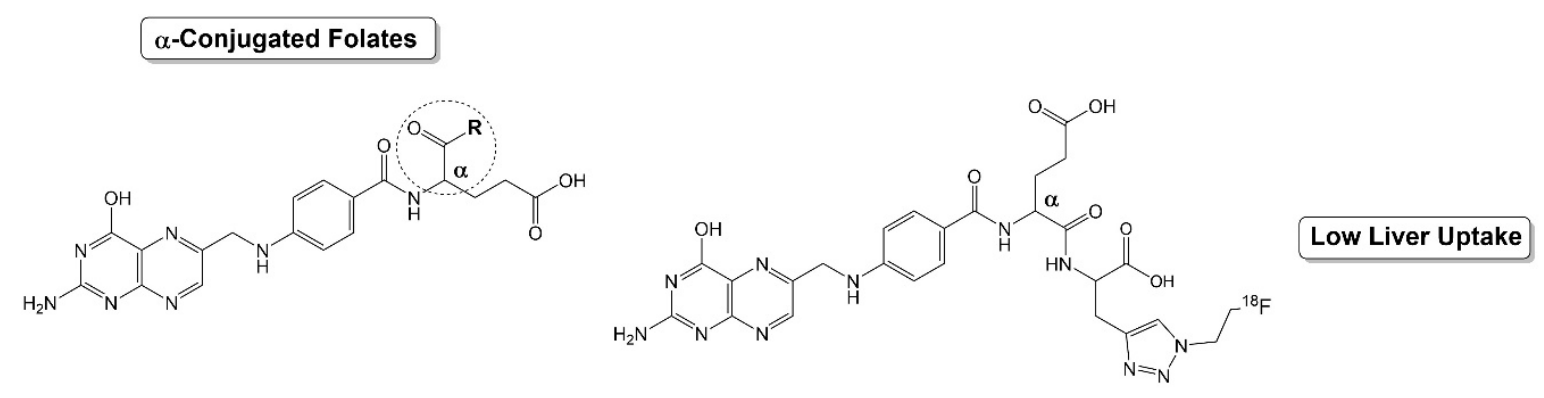
$\alpha$ and $\gamma$ Similar Tumour Uptake

Similar High FR Binging Affinity
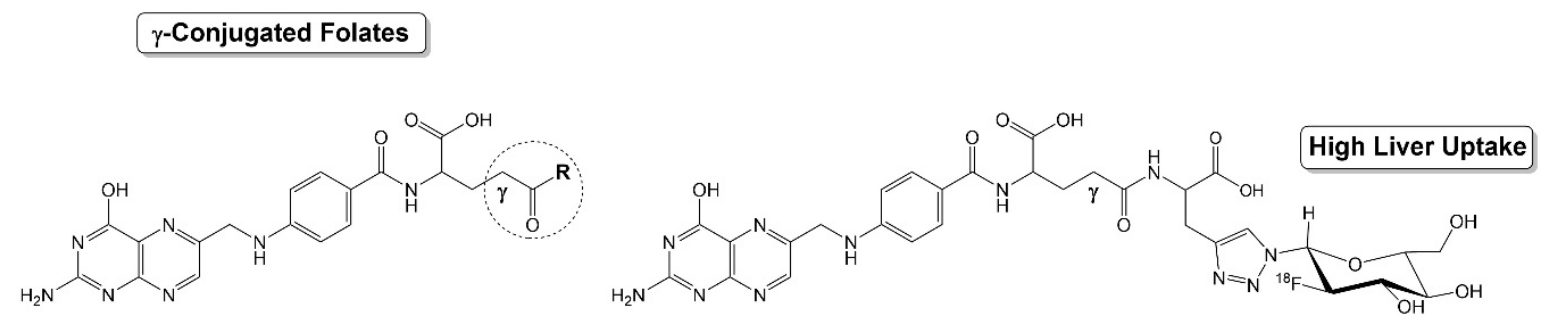

Fig. 4. General structures and two specific examples of $\alpha$ - and $\gamma$-conjugated folic acid positron emission tomography (PET) radiotracers labelled with Fluorine-18. Summary of conjugation site impact on the in vivo behaviour of 18Fbased radiofolates, but not on in vitro FR-binding affinity.[126]

The results of this study demonstrate for the first time that conjugation position on the glutamate moiety of $18 \mathrm{~F}$ labelled folate conjugates has no effect on the in vitro binding affinity toward the FR, but has a considerable 
impact on the in vivo distribution pattern. In addition it should be noted that the $\gamma$ - conjugated folate radiopharmaceutical 99mTc-EC20 cannot be used to detect liver metastasis due to non-specific liver uptake in humans.[127, 128] Liver cells do not express the FR and it is plausible that this non-specific uptake could be due to carrier-mediated uptake via organic anion transporters or proton-coupled folate transporter (PCFT).[126] Given that the PCFT is predominately expressed in the intestines and the liver[129, 130], this non-specific uptake could potentially be overcome with the use of $\alpha$-conjugated folate pharmaceuticals and/or by the formation of cationic folate metal complexes.

\section{COORDINATION COMPLEXES OF FOLIC ACID}

Inorganic medicinal chemistry, as a specific field, has a relatively short history, having its origins in the discovery of the successful anticancer drug, cisplatin, which entered the clinic in 1978.[131] It has since been used in the treatment of various solid neoplastic malignancies including sarcomas and carcinomas such as small cell lung cancer, testicular, ovarian, cervical, endometrial, bladder, head and neck, gastroesophageal and germ cell cancers/tumours.[132-134] It has proven highly effective against testicular cancer in combination with other agents such as bleomycin with cure rates up to $85 \%$.[135]

Cisplatin was the first platinum based solid tumour treatment and it is still extensively utilised, being a major component in first, second and third line treatment regimens for the aforementioned cancer types.[136] The clinical success of the platinum(II) drugs is immense, as they are among the most effective anticancer cytotoxins available and are currently utilised in 50\% of all treatment regimes for solid tumours. The development of coordination complexes with novel structures and possessing biological activity, such as antimicrobial, anti-inflammatory, antioxidant and anticancer, characterizes this exciting field as offering great potential to improve the quality of life.[137-157]

Inorganic medicinal chemistry offers an alternative to organic drugs through opportunities for the design of therapeutics that target different biochemical pathways.[158] The incorporation of metal ions into the molecular structure of a potential drug offers the medicinal chemist an opportunity to exploit structural diversity, have access to various oxidation states of the metal and also offer the possibility of enhancing the activity of an established organic drug through its coordination to the metal centre.[141, 159] Various metals have been utilised for medicinal purposes for almost 5000 years.[160-162] The sterilization of water was achieved by the Egyptians through the use of copper (circa 3000 BC) and gold was applied to limited effect in various remedies almost 3500 years ago in China and Arabia.[163] Around 1500 BC in Egypt, iron was used in a variety of medicines and at approximately the same time zinc was found to aid in wound healing.[164, 165] Interdisciplinary research in the field of inorganic medicinal chemistry is advancing our understanding of metal toxicity and enabling the design of metal-containing compounds as effective and targeted anticancer agents with unique modes of action. 
The coordination chemistry of folic acid, which comprises a pteridine moiety linked via a methylene bridge to para-aminobenzoic acid which in turn is attached to a glutamic acid moiety via an amide bond (Fig. 1), is not well characterised. Metal complexes of pteridines are not common since they are highly $\pi$ electron deficient heterocycles but they are known to form some complexes involving their nitrogen and oxygen atoms (which can exist in either a carbonyl group or an iminol group depending on which tautomeric state prevails).[166] The binding properties of glutamic acid, on the other hand, are well established and it is known to form thermodynamically stable complexes with a range of metals.[167] Very few articles in the literature describe the direct coordination of folate/folic acid to a metal even though such complexes may have interesting biological activity in their own right and they may also have affinity for the folate receptor. Table $\mathbf{1}$ summarises the formulation, mode of coordination and any reported biological properties for the metal folate/folic acid complexes, and relevant related compounds that the authors were able to find in the literature.

The earliest reported synthesis of a metal-folate complex found in the literature was published by a group led by J.J. Pfiffner of Park-Davis and Company in 1947.[168] They were interested in the application of folic acid as an "anti-anaemic factor", and the group focused on its isolation from liver and yeast. The group also synthesized some salts of folic acid including a silver salt of the B vitamin, which involved the reaction of an aqueous solution of folic acid with silver nitrate to yield a yellow microcrystalline product, which they formulated as $\left[\mathrm{Ag}_{2}\right.$ (folate)] on the basis of elemental analysis.[168]

In 2008, Abd El-Wahed et al reported the synthesis and thermal characterisation of simple binuclear transition metal-folate complexes with the general formula $\mathrm{M}_{2} \mathrm{~L} \cdot \mathrm{nH}_{2} \mathrm{O}$ (where $\mathrm{M}=\mathrm{Mn}^{2+}, \mathrm{Co}^{2+}, \mathrm{Ni}^{2+}, \mathrm{Cu}^{2+}, \mathrm{Zn}^{2+}, \mathrm{Cd}^{2+}$ and $\mathrm{Hg}^{2+}$ ; $L=$ folate; $n=1-3,5$ or 15 ), generated by the reaction of sodium folate with the respective metal chlorides.[169] In these complexes the folate anion acts as a dicarboxylate ligand, where the metal ion is coordinated to the $\alpha$ and/or $\gamma$ carboxylate groups of the glutamic acid moiety (Fig. 5 (A)). In addition to the synthesis they also conducted antifungal and antibacterial testing on these simple metal-folate complexes concluding that the cadmium(II), cobalt(II) and nickel(II) folate complexes exhibit activity against Penicillium, Trichoderma and B. subtilis, while a mercury(II) folate complex was shown to exhibit high activity against Penicillium, Trichoderma and E. coli.[169] The generation of $\left[\mathrm{Ag}_{2}\right.$ (folate) $] \cdot 3 \mathrm{H}_{2} \mathrm{O}$ (which the authors believe to be the same as the compound reported by J.J. Pfiffner et al in 1947), via a similar synthetic route, has also been reported recently[170] 
(A)

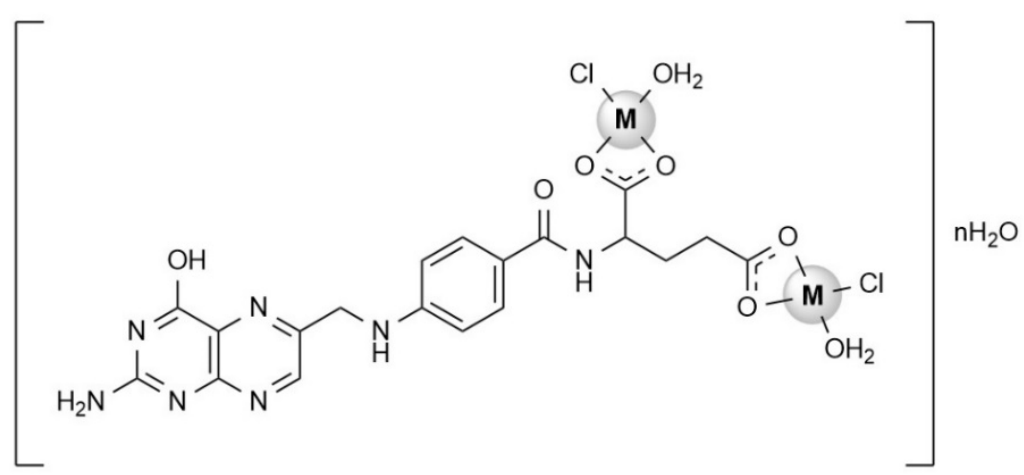

(B)

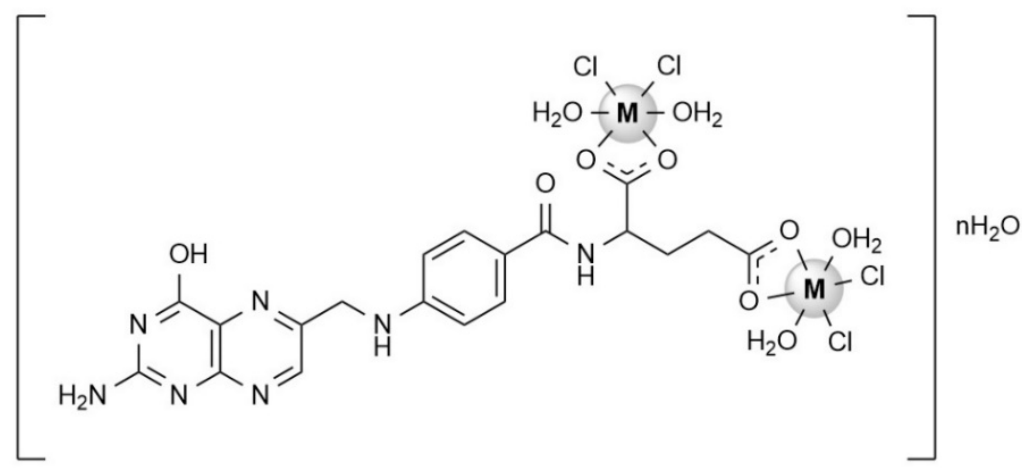

(C)

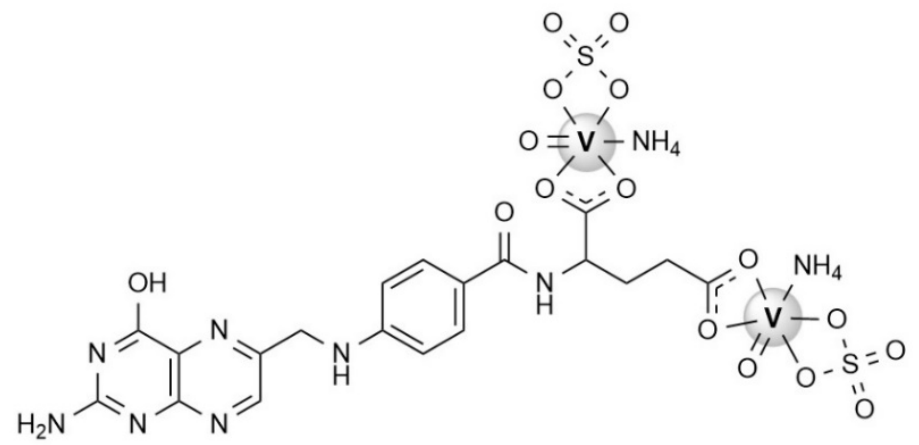

Fig. 5. (A) The structure of various metal folate complexes synthesized by Abd El- Wahed et al.. The structure of the 4 coordinate complexes where $\mathrm{M}=\mathrm{Mn}^{2+}, \mathrm{Co}^{2+}, \mathrm{Ni}^{2+}, \mathrm{Cu}^{2+}, \mathrm{Zn}^{2+}, \mathrm{Cd}^{2+}$ and $\mathrm{Hg}^{2+}$ and $\mathrm{n}=1,3,15,2,0,3$ and 0 , respectively. (B) The structure of the only six coordinate complex where $\mathrm{M}=\mathrm{Fe}^{3+}$ and $\mathrm{n}=7$.[169] (C) The structure of $\left[(\mathrm{VO})_{2}(\mathrm{~L})\left(\mathrm{NH}_{4}\right)_{2}\left(\mathrm{SO}_{4}\right)_{2}\right] \cdot[171]$

In 2016, the synthesis and characterization of a similar simple vanadium(IV) folate complex [(VO) $\left.)_{2}(\mathrm{~L})\left(\mathrm{NH}_{4}\right)_{2}\left(\mathrm{SO}_{4}\right)_{2}\right]$ was also published (Fig. $\left.5(\mathrm{C})\right)$. [171] [(VO) $\left.)_{2}(\mathrm{~L})\left(\mathrm{NH}_{4}\right)_{2}\left(\mathrm{SO}_{4}\right)_{2}\right]$ was isolated from the reaction of vanadyl(II) sulphate and folic acid in an alkaline solution and the complex was found to exhibit antioxidant and anti-DNA damage capabilities.[171] 
Trivalent Lanthanide complexes with the general formula $\mathrm{Ln}_{2} \mathrm{~L}_{3} \cdot \mathrm{nH}_{2} \mathrm{O}\left(\mathrm{Ln}=\mathrm{La}^{3+}\right.$ to $\mathrm{Gd}^{3+}$, except $\mathrm{Pm}^{3+}$; $\mathrm{L}=$ folate; $n=6-9.5$ ) have also been isolated from the reaction of the respective metal chlorides with sodium folate.[172] Although no structure is proposed for these complexes the authors postulate that the folate is bridging the metal centres via the carbonyl groups of the glutamate moiety. More recently, mononuclear iron and copper folate complexes, with the general formula $\mathrm{ML}_{2} \cdot \mathrm{nH}_{2} \mathrm{O}\left(\mathrm{M}=\mathrm{Cu}^{2+}\right.$ or $\mathrm{Fe}^{3+} ; \mathrm{L}=$ folate; $\mathrm{n}=2$ or, respectively) have been reported whereby the metal ions are coordinated to two folate anions via the glutamate moiety which effectively acts as bidentate ligand on the $\alpha$ and $\gamma$ carboxylate groups (Fig. 6 (A)).[173] Using white albino mice treated with $100 \mathrm{mg} / \mathrm{kg}$ of folic acid or the copper-/iron-folate complexes, the authors demonstrated that the complexes were more efficiently absorbed in rodent blood than folic acid itself, which they believe may be due to the increased solubility of the metal-folate complexes. Folate complexes, with the general formula ML. $\mathrm{nH}_{2} \mathrm{O}\left(\mathrm{M}=\mathrm{Mn}^{2+}, \mathrm{Fe}^{2+}, \mathrm{Co}^{2+}, \mathrm{Ni}^{2+}, \mathrm{Cu}^{2+}, \mathrm{Zn}^{2+} ; \mathrm{L}=\right.$ folate; $\left.\mathrm{n}=4-6\right)$ have also been reported. [170, 172, 174] It is proposed that in these complexes the folate also acts as a bidentate ligand via the glutamate moiety but their structures were not confirmed. 
(A)

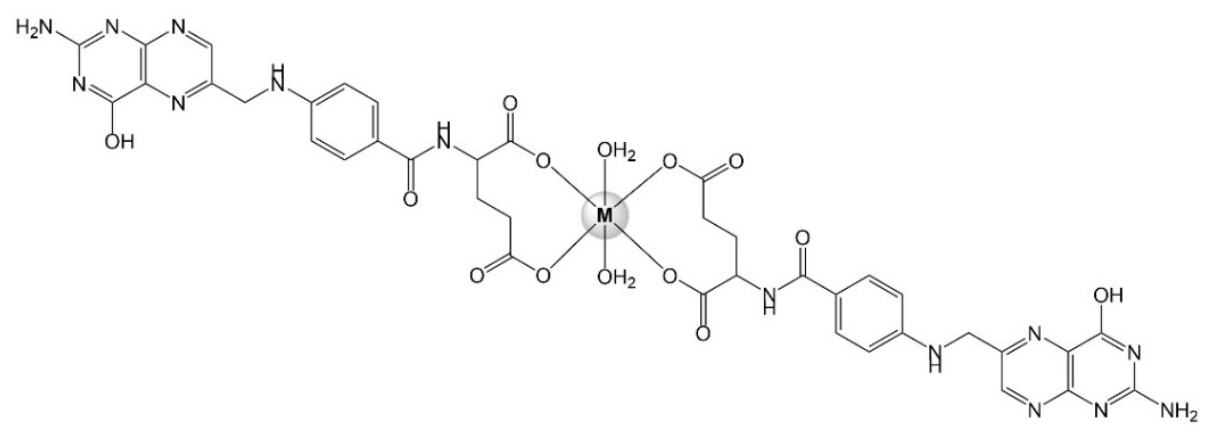

(B)

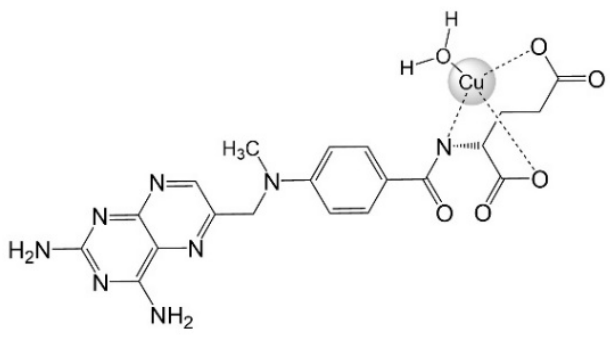

(C)

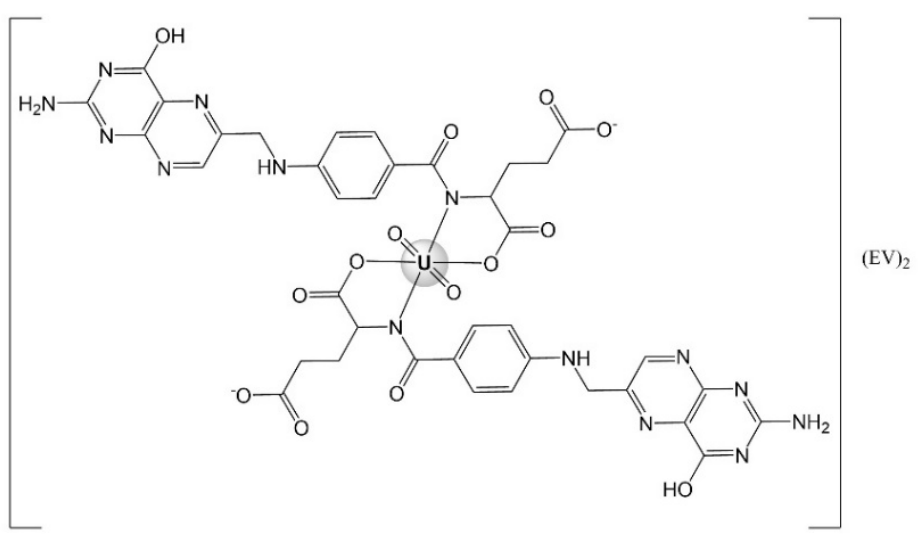

(D)

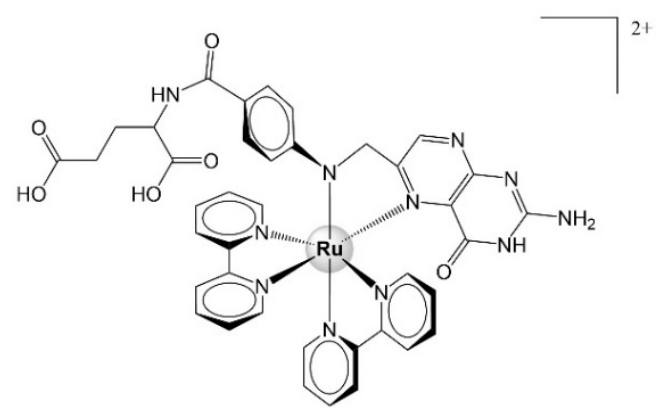

Fig. 6. (A) The proposed structure of the octahedral metal $\left(\mathrm{M}=\mathrm{Cu}^{2+}\right.$ or $\left.\mathrm{Fe}^{3+}\right)$ difolate complexes synthesized by Hamed et al.[173] (B) The proposed structure of the neutral complex $\left[\mathrm{Cu}(\mathrm{MTX})\left(\mathrm{H}_{2} \mathrm{O}\right)\right]\left(\mathrm{MTX}^{2-}=\right.$ dianionic methotrexate) isolated at $\mathrm{pH}$ 7.5.[175] (C) The structure of [ $\mathrm{UO}_{2}$ (folate) $)_{2}$ (EV) $)_{2}(\mathrm{EV}=$ Ethyl Violet).[176] (D) The proposed structure of $\Delta \mathrm{R}$ cis-bis(2,2'-bipyridine)-dichlororuthenium(II), [cis- $\mathrm{Ru}\left(2,2\right.$ '-bipy) ${ }_{2} \mathrm{Cl}_{2}$ ] coordinated to positions the N5 and N10 of folic acid.[177] 
In 2015, Rojo et al reported the synthesis and characterisation of calcium and strontium folates with the general formula ML. $4 \mathrm{H}_{2} \mathrm{O}\left(\mathrm{M}=\mathrm{Ca}^{2+}\right.$ or $\mathrm{Sr}^{2+} ; \mathrm{L}=$ folate), in which the folate also acts as a bidentate ligand via the glutamate moiety.[178] The strontium-folate complex, which was obtained from the reaction of the sodium salt of folic acid with strontium chloride, was shown to have the potential to overcome the toxic effects associated with free $\mathrm{Sr}^{2+}$ ions, a problem associated with the established anti-osteoporosis treatment regimens involving strontium renelate as a bone promoter. Interestingly, in 2015 Nagaj et al reported the copper(II) complex of the antifolate agent methotrexate, an analogue of folic acid (Fig. 1).[175] Potentiometric titrations of $\mathrm{MTX}$ against $\mathrm{CuCl}_{2}$ yielded the neutral complex $\left[\mathrm{Cu}(\mathrm{MTX})\left(\mathrm{H}_{2} \mathrm{O}\right)\right]\left(\mathrm{MTX}^{2-}=\right.$ the doubly deprotonated methotrexate) at $\mathrm{pH} 7.5$ and on the basis of NMR and IR spectral evidence the authors proposed that the MTX $^{2-}$ was bound to the copper(II) centre as a tridentate ligand via the $\alpha$ and $\gamma$ carboxylate and the amide nitrogen functionalities (Fig. 6 (B)). [Cu(MTX)( $\left.\mathrm{H}_{2} \mathrm{O}\right)$ ] was also shown to be an effective nuclease agent in the presence of added hydrogen peroxide and the complex was found to be approximately twice as cytotoxic against mouse colon carcinoma (CT26) and human lung adenocarcinoma (A549) cell lines when compared to the metal-free methotrexate.

During their work on developing a novel method for analyzing folic acid and its metabolites under physiological conditions Xi et al isolated the 2:1 anionic folate-uranium(IV) complex salt $\left[\mathrm{UO}_{2}(\text { folate })_{2}\right](\mathrm{EV})_{2}$ (where $\mathrm{EV}^{+}=$the cation of the basic triphenylmethane dye ethyl violet) in aqueous solution at $\mathrm{pH}$ 4.2-4.8.[176] Based on charge density calculations it is proposed that in the structure of $\left[\mathrm{UO}_{2}(\text { folate })_{2}\right](\mathrm{EV})_{2}$ that the folate ligands are coordinated to the uranium atoms in the $\mathrm{UO}_{2}{ }^{2+}$ moieties via the nitrogen atom of the imido-group of the aminocarboxyl and the oxygen atom of the $\alpha$-carbonyl to form stable five-membered chelate rings (Fig. 6 (C)).

In 1992 Schwederski et al reported the synthesis of the ruthenium complex cation [cis-Ru(2,2'-bipy) 2 (FA) $]^{2+}$ (FA = folic acid) in which they postulated, based on a limited analysis, that a neutral folic acid ligand was bound to the ruthenium, as an $\alpha$-iminocarbonyl chelate, via the carbonyl oxygen and a nitrogen atom of the pteridine moiety.[179] More recently, in an effort to investigate the interaction of ruthenium complexes with intracellular biomolecules, Scrase and colleagues reported the isolation of $\left.[\text { cis-Ru(2,2'-bipy })_{2}(\mathrm{FA})\right]^{2+}$ under physiologically relevant conditions.[177] The diastereomers of the complex dication were isolated, as the hexafluorophosphate salts subsequent to the reaction of [cis- $\mathrm{Ru}\left(2,2^{\prime} \text {-bipy }\right)_{2} \mathrm{Cl}_{2} \cdot 2 \mathrm{H}_{2} \mathrm{O}$ ] with one equivalent of folic acid in aqueous solution. The complex was characterised extensively by NMR and MS which revealed that the folic acid acts as a neutral chelating ligand involving a nitrogen atom from the pteridine group and the amine nitrogen of the para-aminobenzoic acid moiety (Fig. 6 (D)).[177] These authors also repeated the synthesis of the complexes reported by Schwederski et al and confirmed that the two complexes were identical. In addition, the group experimented with altered protonation states of folic acid and confirmed that the binding of the neutral folic acid was contingent on its ability to act as the $\mathrm{N}-\mathrm{N}$ chelate.

This N-N chelate mode of coordination had previously been reported in a platinum(II) complex generated when the cis-diaminediaquaplatinum(II) cation was reacted with the reduced folate tetrahydrofolate at $\mathrm{pH} 7$ and 37 
${ }^{\circ} \mathrm{C}$ to generate the pure complex in 70\% yield.[180] The elemental analysis, NMR and absorbance spectroscopies over a range of $\mathrm{pH}$ values were used to confirm that the diamine platinum moiety was bridged across the N5 and N10 positions of the tetrahydrofolate. Interestingly, whereas similar complexes were isolated for 5-methylhydrofolate, 5formyltetrahydrofolate, methotrexate and aminopterin, these authors reported that the diamine platinum cation did not react with either folate and 7,8-dihydrofolate. The biological implications of these observations were also investigated and the cis-diaminediaquaplatinum(II)tetrahydrofolate complex was found to be a reasonably good inhibitor of dihydrofolate reductase $(\mathrm{Ki}=4 \mu \mathrm{M})$ and of the folate transport system $(50 \%$ inhibition at $200 \mu \mathrm{M})$ in the mouse lymphocytic leukemia cells line (L1210). It is noteworthy that there is no apparent cell death caused by the cisdiaminediaquaplatinum(II)tetrahydrofolate complex at $200 \mu \mathrm{M}$ during the folate transport inhibition study suggesting that it would not be capable of exerting a cytotoxic response in the same way as cisplatin, possibly due to the lack of labile coordination sites in its structure.

Two very interesting nickel(II) and cobalt(II) biomolecule-based coordination complex nanotubes (BMBCCNT's), with the molecular formula of the monomeric unit $\left\{\mathrm{M}_{2}\right.$ (folate) $\left.\left(\mathrm{N}_{2} \mathrm{H}_{4}\right)_{3}(\mathrm{OH})_{2}\left(\mathrm{H}_{2} \mathrm{O}\right)_{2}\right\} \mathrm{f}\left(\mathrm{M}=\mathrm{Ni}^{2+}\right.$ or $\left.\mathrm{Co}^{2+}\right)$ have recently been reported.[181, 182] These BMB-CCNT's were synthesised in good yield by a method involving ultrasonification of folic acid with the respective metal(II)chloride in a 1:2 molar ratio and with the addition of $10 \mathrm{~mL}$ of aqueous hydrazine (at pH 10.5) in an ethanol/water mixture (20/80) followed by the heating in an autoclave to 120 ${ }^{\circ} \mathrm{C}$ to yield the product. Similar attempts to generate the $\mathrm{Zn}^{2+}, \mathrm{Ca}^{2+}, \mathrm{Fe}^{2+}$ and $\mathrm{Cu}^{2+}$, analogues were unsuccessful and the authors reported the recovery of only the corresponding metal oxides from these reactions. The structure of the $\left\{\mathrm{Ni}_{2} \text { (folate) }\left(\mathrm{N}_{2} \mathrm{H}_{4}\right)_{3}(\mathrm{OH})_{2}\left(\mathrm{H}_{2} \mathrm{O}\right)_{2}\right\}_{\mathrm{n}}$ nanotubes (Fig. 7) was confirmed by an array of physicochemical techniques.

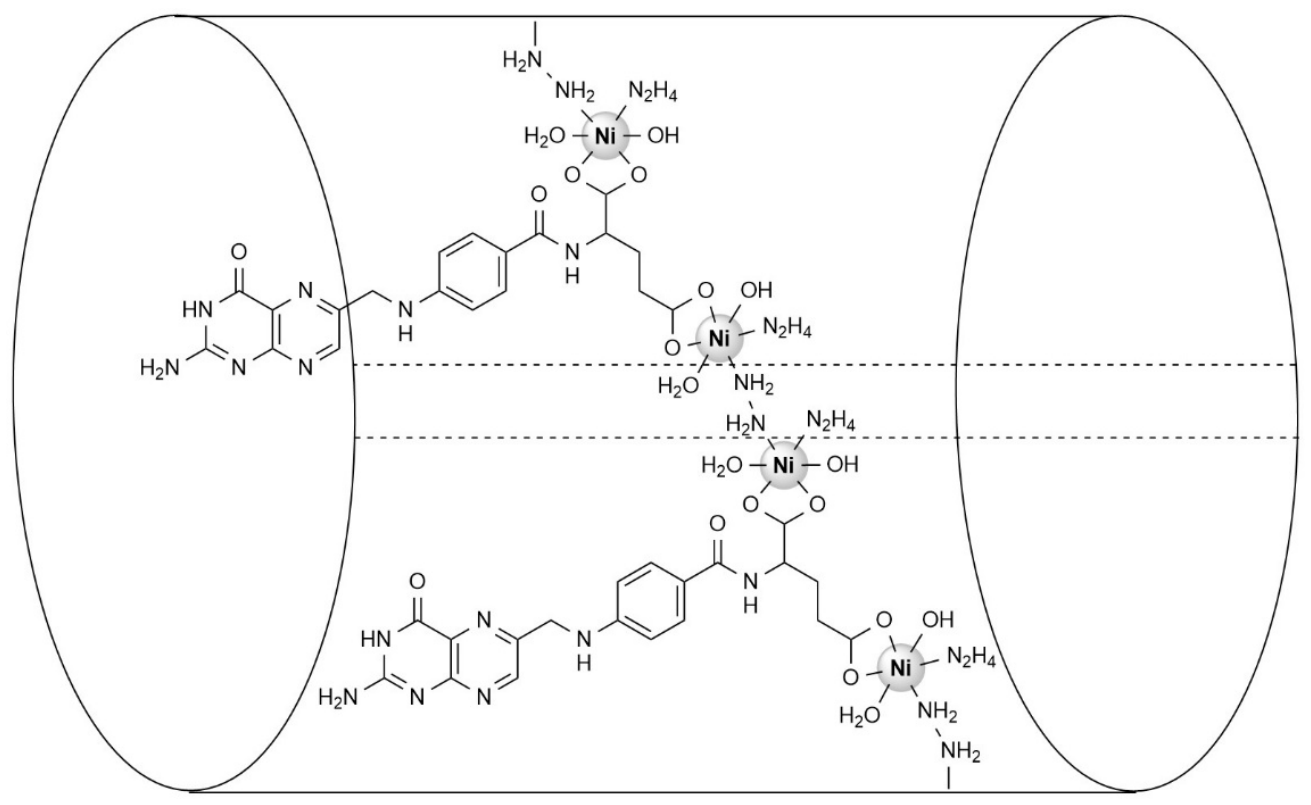

Fig. 7. The proposed structure of nickel(II) biomolecule-based coordination complex nanotubes (BMB-CCNT's), with the molecular formula of the monomeric unit being $\left\{\mathrm{Ni}_{2}(\text { folate })\left(\mathrm{N}_{2} \mathrm{H}_{4}\right)_{3}(\mathrm{OH})_{2}\left(\mathrm{H}_{2} \mathrm{O}\right)_{2}\right\}_{\mathrm{n}}$. [182] 
The folate ligand is bound to the $\mathrm{M}^{2+}$ ions via its carboxylate groups, which act as bidentate chelates and the nanotubes comprise a polymeric structure in which the metal ions are at the centre of octahedral coordination sphere with hydrazine ligands bridging neighbouring $\mathrm{M}^{2+}$ to each other and with hydrogen bonding involving the pteroic moiety of the folate forming a tape-like structure (Fig. 7). To demonstrate the importance of the hydrazine in the role of the nanotube formation these workers also reacted folic acid with nickel(II) chloride in the presence of ammonia or sodium hydroxide instead of the hydrazine under the same experimental conditions.[182] Using transition electron microscopy (TEM) imaging the resulting complexes, for which the authors did not provide formulation data, were found to form non-nanotubular structures.

The $\left\{\mathrm{Ni}_{2} \text { (folate) }\left(\mathrm{N}_{2} \mathrm{H}_{4}\right)_{3}(\mathrm{OH})_{2}\left(\mathrm{H}_{2} \mathrm{O}\right)_{2}\right\}_{\mathrm{n}}$ nanotubes were tested for their activity against human cervical cancer HeLa cells (FR+ve), human lung adenocarcinoma cancer A549 cells (FR-ve) and normal human embryonic lung fibroblasts HELF cells (FR-ve).[182] The results showed that the $\left\{\mathrm{Ni}_{2}(\text { folate })\left(\mathrm{N}_{2} \mathrm{H}_{4}\right)_{3}(\mathrm{OH})_{2}\left(\mathrm{H}_{2} \mathrm{O}\right)_{2}\right\}_{\mathrm{n}}$ nanotubes exhibited comparable cytotoxicity to cisplatin and that they are selective for the FR+ve HeLa cells ( $\mathrm{IC}_{50}=0.586$ $\mu \mathrm{g} / \mathrm{ml}, \quad 0.855 \mu \mathrm{g} / \mathrm{ml}$ and $10.139 \mu \mathrm{g} / \mathrm{ml}$ for the HeLa, A549 and HELF cell lines, respectively). The $\left\{\mathrm{Co}_{2} \text { (folate) }\left(\mathrm{N}_{2} \mathrm{H}_{4}\right)_{3}(\mathrm{OH})_{2}\left(\mathrm{H}_{2} \mathrm{O}\right)_{2}\right\}_{\mathrm{n}}$ nanotubes were also tested for their cytotoxicity and they were found to be even more selective for the FR+ve over FR-ve cells ( IC $_{50}=0.1 .47 \mu \mathrm{g} / \mathrm{ml}, 5.43 \mu \mathrm{g} / \mathrm{ml}$ and $20.32 \mu \mathrm{g} / \mathrm{ml}$ for the HeLa, A549 and normal human liver L-O2 cell lines, respectively).[181] Further interest is derived in this class of material in that the inner tubes of the $\left\{\mathrm{M}_{2} \text { (folate) }\left(\mathrm{N}_{2} \mathrm{H}_{4}\right)_{3}(\mathrm{OH})_{2}\left(\mathrm{H}_{2} \mathrm{O}\right)_{2}\right\}_{\mathrm{n}}$ nanotubes can easily be loaded with clinical drugs such as cisplatin or doxorubicin to yield dual action therapeutics. Cellular uptake studies demonstrated that the drug loaded nanotubes, which are stable at physiological $\mathrm{pH}$, enter cells through a FR mediated endocytic mechanism and that they are broken down to release the active components in the acidic environment inside the cell. The fundamental pharmacokinetic profiles and biodistribution of the $\left\{\mathrm{Co}_{2}(\text { folate })\left(\mathrm{N}_{2} \mathrm{H}_{4}\right)_{3}(\mathrm{OH})_{2}\left(\mathrm{H}_{2} \mathrm{O}\right)_{2}\right\}_{n}$ nanotubes in mice are also reported along with its very positive in-vivo antitumour activity.[181] 
Table 1: Formulae, mode of coordination and biological properties for the metal folate/folic acid complexes.

\begin{tabular}{|c|c|c|c|}
\hline Formulae & Binding mode of the folate/folic acid & Biological activity & Reference \\
\hline $\begin{array}{l}\mathrm{M}_{2}(\text { folate }) \cdot \mathrm{nH}_{2} \mathrm{O}\left(\mathrm{M}=\mathrm{Mn}^{2+}, \mathrm{Co}^{2+}, \mathrm{Ni}^{2+}, \mathrm{Cu}^{2+} \text {, }\right. \\
\left.\mathrm{Zn}^{2+}, \mathrm{Cd}^{2+} \text { and } \mathrm{Hg}^{2+} ; \mathrm{n}=1-3,5 \text { or } 15\right)\end{array}$ & $\begin{array}{l}\text { Bidentate bridging via } \alpha \text { and } \gamma \text { carboxylate } \\
\text { groups }\end{array}$ & Antifungal and antibacterial activity & [169] \\
\hline$\left[\mathrm{Ag}_{2}\right.$ (folate) $] .3 \mathrm{H}_{2} \mathrm{O}$ & $\begin{array}{l}\text { Bidentate bridging via } \alpha \text { and } \gamma \text { carboxylate } \\
\text { groups }\end{array}$ & None reported & {$[170]$} \\
\hline$\left[(\mathrm{VO})_{2}(\right.$ folate $\left.)\left(\mathrm{NH}_{4}\right)_{2}\left(\mathrm{SO}_{4}\right)_{2}\right]$ & $\begin{array}{l}\text { Bidentate bridging via } \alpha \text { and } \gamma \text { carboxylate } \\
\text { groups }\end{array}$ & $\begin{array}{l}\text { Antioxidant and anti-DNA damage } \\
\text { capabilities. }\end{array}$ & {$[171]$} \\
\hline $\begin{array}{l}\left.\mathrm{Ln}_{2} \text { (folate) }\right)_{3} \cdot \mathrm{nH}_{2} \mathrm{O}\left(\mathrm{Ln}=\mathrm{La}^{3+} \text { to } \mathrm{Gd}^{3+} \text {, except }\right. \\
\left.\mathrm{Pm}^{3+} ; \mathrm{n}=6-9.5\right)\end{array}$ & $\begin{array}{l}\text { Bidentate bridging via } \alpha \text { and } \gamma \text { carboxylate } \\
\text { groups }\end{array}$ & None reported & {$[172]$} \\
\hline $\begin{array}{l}\mathrm{M}(\text { folate })_{2} \cdot \mathrm{nH}_{2} \mathrm{O}\left(\mathrm{M}=\mathrm{Cu}^{2+} \text { or } \mathrm{Fe}^{3+} ; \mathrm{n}=2 \text { or, }\right. \\
\text { respectively })\end{array}$ & $\begin{array}{l}\text { Bidentate chelating via the } \alpha \text { and } \gamma \\
\text { carboxylate groups }\end{array}$ & $\begin{array}{l}\mathrm{M}(\text { folate })_{2} \cdot \mathrm{nH}_{2} \mathrm{O} \text { absorbed more efficiently in } \\
\text { rodent blood than metal-free folic acid }\end{array}$ & {$[173]$} \\
\hline $\begin{array}{l}\mathrm{M}(\text { folate }) \cdot \mathrm{nH}_{2} \mathrm{O}\left(\mathrm{M}=\mathrm{Mn}^{2+}, \mathrm{Fe}^{2+}, \mathrm{Co}^{2+}, \mathrm{Ni}^{2+}\right. \\
\left.\mathrm{Cu}^{2+}, \mathrm{Zn}^{2+} ; \mathrm{n}=4-6\right)\end{array}$ & $\begin{array}{l}\text { Bidentate chelating via the } \alpha \text { and } \gamma \\
\text { carboxylate groups }\end{array}$ & None reported & {$[170,174]$} \\
\hline $\mathrm{M}($ folate $) \cdot 4 \mathrm{H}_{2} \mathrm{O}\left(\mathrm{M}=\mathrm{Ca}^{2+}\right.$ or $\left.\mathrm{Sr}^{2+}\right)$ & $\begin{array}{l}\text { Bridging Bidentate via } \alpha \text { and } \gamma \text { carboxylate } \\
\text { groups }\end{array}$ & $\mathrm{Sr}$ (folate). $4 \mathrm{H}_{2} \mathrm{O}$ is a non-toxic bone promoter & [178] \\
\hline $\begin{array}{l}{\left[\mathrm{Cu}(\mathrm{MTX})\left(\mathrm{H}_{2} \mathrm{O}\right)\right]\left(\mathrm{MTX}^{2-}=\text { the doubly }\right.} \\
\text { deprotonated methotrexate })\end{array}$ & $\begin{array}{l}\text { Tridentate ( } \alpha \text { and } \gamma \text { carboxylate groups and } \\
\text { the amide nitrogen of the glutamate moiety) }\end{array}$ & Nuclease active and cytotoxicity & {$[175]$} \\
\hline $\begin{array}{l}{\left[\mathrm{UO}_{2}(\text { folate })_{2}\right](\mathrm{EV})_{2}\left(\mathrm{EV}^{+}=\text {the cation of the }\right.} \\
\text { basic triphenylmethane dye ethyl violet })\end{array}$ & $\begin{array}{l}\text { Chelating via } \alpha \text { carboxylate and amide } \\
\text { nitrogen of the glutamate moiety }\end{array}$ & None reported & {$[176]$} \\
\hline$[\text { cis-Ru(2,2’-bipy })_{2}$ (folic acid) $]^{2+}$ & Chelating via N5 and N10 nitrogen atoms & None reported & {$[177,179]$} \\
\hline$\left[\right.$ cis- $\mathrm{Pt}\left(\mathrm{NH}_{3}\right)_{2}\left(\mathrm{H}_{2} \mathrm{O}\right)_{2}($ tetrahydrofolate $\left.)\right]$ & Chelating via N5 and N10 nitrogen atoms & $\begin{array}{l}\text { Dihydrofolate reductase and folate transport } \\
\text { system inhibition in L1210 cell line }\end{array}$ & {$[180]$} \\
\hline $\begin{array}{l}\left\{\mathrm{M}_{2}(\text { folate })\left(\mathrm{N}_{2} \mathrm{H}_{4}\right)_{3}(\mathrm{OH})_{2}\left(\mathrm{H}_{2} \mathrm{O}\right)_{2}\right\}_{\mathrm{n}} \quad\left(\mathrm{M}=\mathrm{Ni}^{2+}\right. \\
\left.\text { or } \mathrm{Co}^{2+}\right)\end{array}$ & $\begin{array}{l}\text { Bidentate bridging via } \alpha \text { and } \gamma \text { carboxylate } \\
\text { groups }\end{array}$ & $\begin{array}{l}\text { FR+ve selective cytotoxicity; where } \mathrm{M}=\mathrm{Co}^{2+} \\
\text { - in-vivo antitumour activity in mice. }\end{array}$ & {$[181,182]$} \\
\hline
\end{tabular}




\section{FOLATE-METAL COMPLEX CONJUGATES AS TARGETED THERAPEUTIC AGENTS}

As well as its ability to act as a ligand in its own right folic acid can also be conjugated to small or large biologically active metal complexes through either direct folate coupling or folate coupling via a spacer. The inclusion of a linker allows for effective unhindered binding of the folate moiety to the FR and control over the lipophilicity of the folate conjugate, which are requirements for cellular internalization of the entire molecule through endocytosis (Fig. 8). Furthermore, if required, selective delivery of a therapeutic metal complex can be achieved by the inclusion of a suitable cleavable bond which can facilitate the dissociation of the active payload from the folate carrier once the folate-metal complex conjugate is endocytosed. Generally, unless otherwise stated, the synthesis of the compounds in reviewed in this section and in section 5 involve the following methods for conjugate formation: (i) the formation of an amide bond involving the reaction of a carboxylic acid group ( $\alpha$ and/or $\gamma$ ) of the glutamate moiety of the folic acid with an amine $\left(-\mathrm{NH}_{2}\right)$ functionality on the linker (generally an alkyl diamine molecule, PEG derivate or amino acid) which in turn can be bound to the coordination complex via a second amide bond (Fig. 8); (ii) direct conjugation of folic acid to the active metal complex via an amide bond. Alternative strategies involve encapsulation of active metal complexes within folate-conjugated carriers.

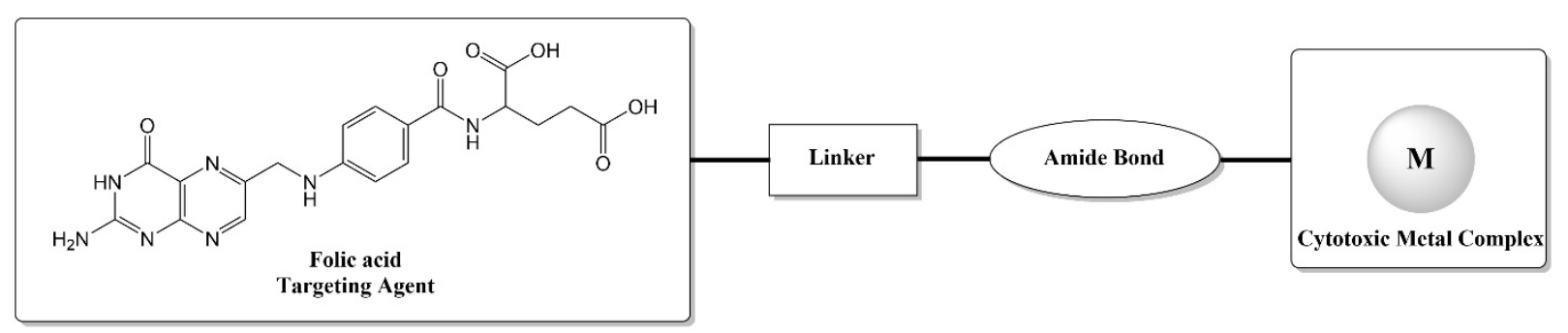

Fig. 8. Structural design of a folate-metal complex conjugate comprising the folate targeted moiety, the optional linker and the amide bond formation to the active metal complex.

\subsection{Platinum-based systems}

Platinum-based drugs play a key role in treatment regimens of a range of cancers. However, their applicability and efficacy are plagued by limitations regarding drug resistance and adverse toxic side effects. The ability to selectively deliver this class of drug through targeted strategies has recently been an area of intense research.[183-185] Table 2 summarises the structural and biological profiles of the known platinum-folate conjugate systems.

The systematic preparations of folate conjugates of cisplatin and carboplatin were recently reported.[186] The multi-step synthesis involved the direct attachment of diamine and dicarboxylate functionalities to the glutamate 
moiety of folic acid followed by reaction with the respective platinum(II) salts to yield five different derivatives (Fig. 9). Although this approach yielded desirable structures, the folate-complex conjugates were not studied for their cytotoxicity or FR uptake capabilities due to their poor solubility.

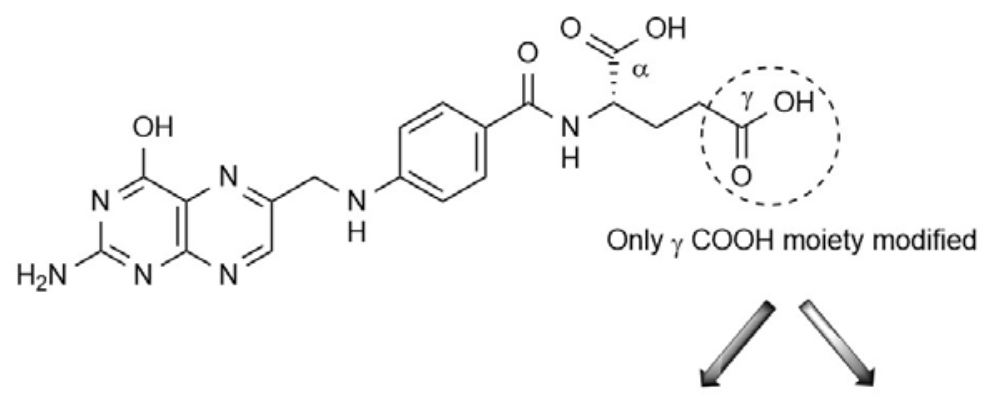

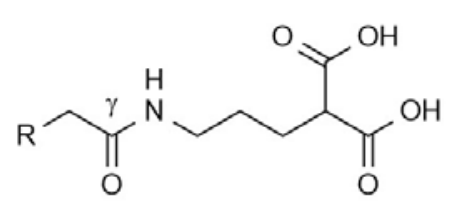

L.3

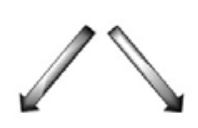

(L3)Pt( $\left(\mathrm{NH}_{3}\right)_{2} \quad(\mathrm{~L} 3) \mathrm{Pt}\left(\mathrm{NH}_{2} \mathrm{CH}_{3}\right)_{2}$
AND<smiles>[R]CC(=O)NC(C(=O)O)C(=O)O</smiles>

L2

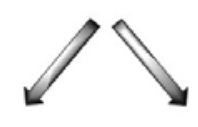

(L.2) $\mathrm{Pt}\left(\mathrm{NH}_{3}\right)_{2}$

(L2) $\mathrm{Pt}\left(\mathrm{NH}_{2} \mathrm{CH}_{3}\right)_{2}$<smiles>[R]CC(=O)NCCNC(=O)C(N)CN</smiles>

L1

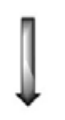

(L1) $\mathrm{PtCl}_{2}$

Fig. 9. The general synthetic scheme of folate-conjugates of cisplatin-like and carboplatin-like complexes.[186]

Many attempts have been made to enhance the therapeutic potential of platinum anticancer drugs through their conjugation to large polymeric carrier molecules such as polyethyleneglycols (PEG's) which are known to increase their solubilities in water.[185] Although this approach can significantly improve pharmacokinetics and tissue distribution of the drug, cell permeability can remain a problem due to the relatively high molecular weights of such conjugates.[187] This poses a particular problem for platinum complexes in that if they are released in the extracellular medium, they can act as nonspecific electrophiles, and then be rapidly inactivated by extracellular nucleophiles. To address this issue Aronov et al prepared the carboplatin conjugate FA-PEG-Carboplatin (Fig. 10 (A)) and studied its cellular uptake, its effect on the rate of DNA platination and its relative cytotoxicity.[188] They also synthesized the fluorescent analogue FA-PEG-FITC (FITC = fluorescein isothiocyanate) to enable them to explore the effects of the conjugation on the cellular uptake of the PEG system using confocal microscopy and fluorescenceassisted cell sorting (FACS). The synthesis of the FA-PEG-Carboplatin is arduous, involving six steps, and requiring significant purification and characterization. Indeed, the authors claim this to be the first time a complete chemical 
characterization of Pt-PEG conjugates was undertaken, involving ${ }^{1} \mathrm{H}$ NMR, ${ }^{195} \mathrm{Pt} \mathrm{NMR}$, and $2 \mathrm{D}-\left[{ }^{1} \mathrm{H},{ }^{15} \mathrm{~N}\right]$ heteronuclear single quantum correlation (HSQC) spectroscopy.

(A)

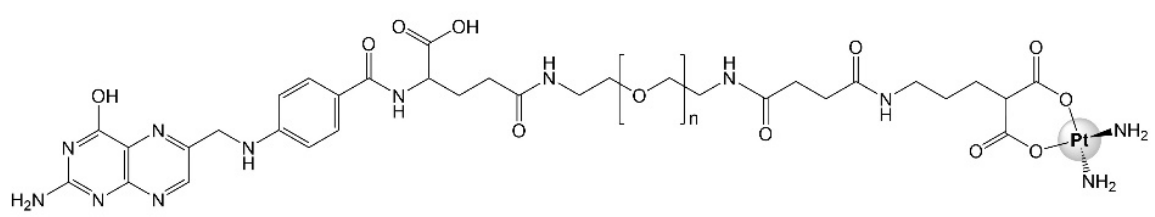

(B)<smiles>CNC(=O)C(CC(=O)NC1C(=O)OC2(N)OC(=O)C1C(=O)O2)NC(=O)CC(NC(=O)CCC(=O)NC1O[C@@H](N)[C@H](N)OC1=O)C(=O)NCC(=O)NCCOC(C)(C)CCNC(=O)CCC(NC(=O)c1ccc(NCc2cnc3nc(N)nc(O)c3n2)cc1)C(=O)O</smiles>

(C)

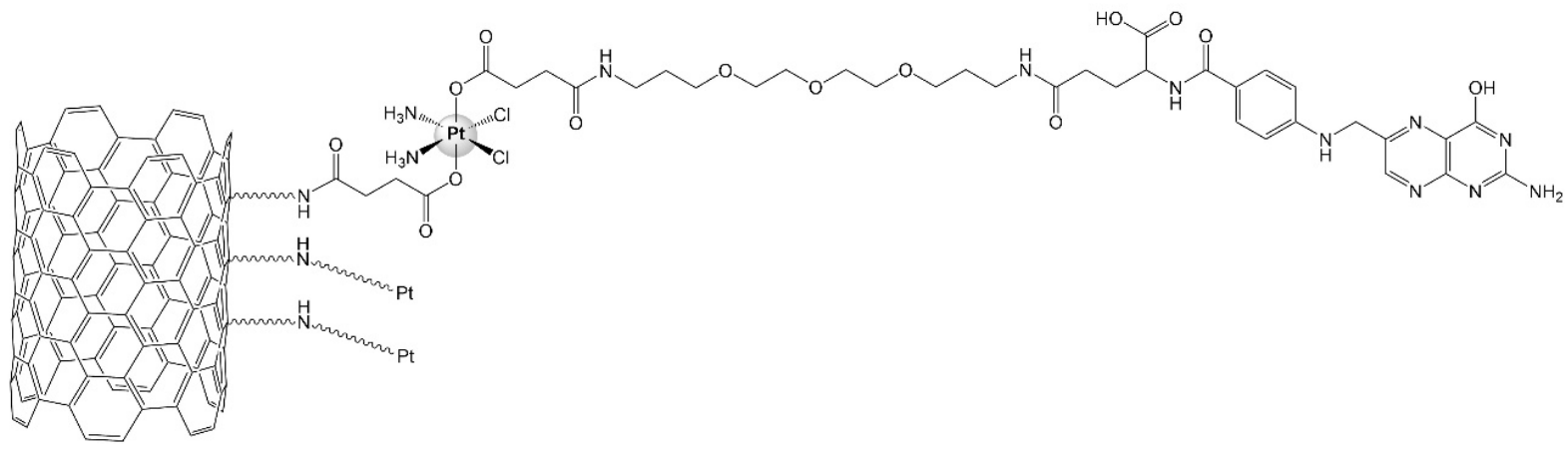

Fig. 10. (A) The structure of the FA-PEG-Carboplatin conjugate.[188] (B) The proposed structure of a single unit of the folate conjugate Cisplatin-FA-PEG-g-PAsp-Ami polymer.[189] (C) The proposed structure of a platinum(IV) containing a folate derivative (FA) at an axial position, attached to the surface of an amine-functionalized singlewalled carbon nanotube (SWNT-PL-PEG-NH ${ }_{2}$ ) through multiple amide linkages.[190]

Using a folate receptor-enriched cell line, M109HiFR, these researchers conducted drug uptake and cytotoxicity studies as well as the determination of Pt-adduct formation. Results showed that the folate-targeted FAPEG-Carboplatin conjugate was less cytotoxic than both its untargeted PEG-Carboplatin counterpart and the free drug carboplatin, despite exhibiting increased drug uptake via endocytosis. The untargeted PEG-Carboplatin conjugate produced higher levels of DNA binding than the folate-targeted FA-PEG-Carboplatin conjugate, thus accounting for its low cytotoxicity. It was suggested that this unexpected phenomenon may be due to the folate receptor-mediated endocytic pathway, in which folate-conjugates are not released into the cytosol but rather are directed to acidic 
lysosomes or endosomes, thereby limiting access to the nucleus. The findings suggest that the folate-targeted conjugate FA-PEG-Carboplatin may be unsuitable as a prodrug for the carboplatin family, as the conjugate appears to be neutralized or blocked during the folate receptor-mediated endocytosis process, resulting in entrapment of the prodrug in certain cellular compartments. The authors concluded that folate targeting may not be an appropriate delivery system for Pt-based drugs as the active moieties may become neutralised or hindered by the folate receptormediated endocytic system.

In an attempt to reduce toxic side effects while enhancing its antitumor activity the incorporation of cisplatin into a polymeric folate conjugate with PEG-graft- $\alpha, \beta$-poly[(N-amino acidyl)-aspartamide] (Cisplatin-FA-PEG- $g$ PAsp-Ami) has also been studied recently (Fig. 10 (B)).[189] The targeted polymer-metal complex micelles were prepared by stirring cisplatin with the FA-PEG-g-PAsp-Ami in distilled water for 24 hours at $37{ }^{\circ} \mathrm{C}$, followed by purification by dialysis and characterization by measurement of critical aggregation concentration, particle size and morphological observations. Cytotoxicity was determined in the oral cancer KB cell line (FR+ve), by treating the cells with the folate targeted Cisplatin-FA-PEG- $g$-PAsp-Ami and untargeted Cisplatin-PEG- $g$-PAsp-Ami complexes in folate deficient media for $24 \mathrm{~h}$. The results showed that the folate-conjugated complex was far more cytotoxic (50\% cell viability at $100 \mu \mathrm{g} / \mathrm{ml}$ concentration) to the cell line than the non-targeted system (> 60\% cell viability at 100 $\mu \mathrm{g} / \mathrm{ml}$ concentration), due to folate receptor mediated endocytic uptake of the compound. Additional inhibition assays using excess folic acid supported the role of FR targeting for the Cisplatin-FA-PEG-g-PAsp-Ami (70\% cell viability at $100 \mu \mathrm{g} / \mathrm{ml}$ concentration in the presence of $1 \mathrm{mg} / \mathrm{ml}$ of added folic acid). In vivo testing in male athymic mice exhibited similar results, indicating that Cisplatin-FA-PEG-g-PAsp-Ami micelles were well tolerated by the mice, and exhibited great potential as tumour targeted cisplatin alternatives.

In 2012, Chaudhury et al reported the use of intraperitoneal (IP) administration coupled with a folate receptortargeted (FRT) liposomal system intended to achieve intracellular delivery of carboplatin with a view to increasing the therapeutic efficacy and reducing toxicity of the drug for the purpose of IP treatment of ovarian cancer.[191] The authors discussed the limitations of IP administration of chemotherapy and the advantages of a drug delivery system such as an FR targeted liposomal system, which could deliver a drug payload into ovarian cancer cells. Initial fluorescence studies on IGROV-1 cells before injection showed a twofold increase in cellular accumulation of the folate targeted platinum compared to the non-targeted carboplatin. From here, cytotoxicity studies showed that a concentration as low as $13 \mu \mathrm{M}$ of folate-targeted carboplatin could induce cell death in 50\% of IGROV-1 cells in vitro, while both the free drug and non-targeted conjugate required $24-45 \mu \mathrm{M}$ respectively. The authors also used an intraperiotenally grown human IGROV-1 ovarian tumor xenograft mouse model (selected to mimic the clinical nature of tumour burden in women with advanced-stage ovarian cancer and overexpression of FR). These in-vivo studies identified that 5 out of 6 FR targeted carboplatin liposome treated mice (83\%) survived to the end of the study, whereas the non-targeted carboplatin treated liposome group, free drug or saline treated control all died within 19-39 days posttumour inoculation. Of the $83 \%$ mice that survived treatment, none showed weight-loss or metastasis. The authors concluded that intraperitoneal (IP) administration of folate-targeted carboplatin liposomes has the potential to extend 
the overall survival of ovarian cancer patients as well as maintaining therapeutic efficacy with reduced risk of regimenrelated toxicities.

A similar strategy was also reported for the targeted delivery of a mixture of the arsenic- and platinum-based drugs in a single folate-functionalised liposome.[192] The co-encapsulation of $\left[\mathrm{As}(\mathrm{OH})_{3}\right]$ and $\left[\mathrm{Pt}\left(\mathrm{NH}_{3}\right)_{2}\left(\mathrm{H}_{2} \mathrm{O}\right)_{2}\right]^{2+}$ in the folate-functionalised liposome, which the authors refer to as a 'nanobin', facilitated efficient delivery of the anticancer drug combination with preferential uptake in the KB nasopharyngeal cell line (FR+ve) compared to MCF7 breast cancer cells (FR-ve).

Folate conjugated nanogels (swollen polymers containing ca. 95\% water), which have very high loading capabilities, have also been demonstrated to be effective targeted delivery systems for cisplatin with preferential uptake in A2780 human ovarian carcinoma cells (FR+ve) and superior antitumour activity towards A2780 xanografts in contrast to cisplatin on its own.[193] FR mediated endocytosis has also been achieved when $\left[\mathrm{Pt}\left(\mathrm{NH}_{3}\right)_{2}\left(\mathrm{H}_{2} \mathrm{O}\right)_{2}\right]^{2+}$, folic acid and rhodamine B isothiocyanate were conjugated onto magnetic calcium phosphate nanoparticles, with its cytotoxicity being fourfold and onefold more active against HeLa human cervical cancer cells (FR+ve) and L929 human cervical cancer cells (FR-ve), respectively, when compared to the activities of $\left[\mathrm{Pt}\left(\mathrm{NH}_{3}\right)_{2}\left(\mathrm{H}_{2} \mathrm{O}\right)_{2}\right]^{2+}$ on its own.[194]

An interesting approach to targeting platinum drugs towards cancer cells was reported by Lippard et al by attaching the folate-PEG derivative $c, c-t-\left[\mathrm{Pt}\left(\mathrm{NH}_{3}\right)_{2} \mathrm{Cl}_{2}\left(\mathrm{O}_{2} \mathrm{CCH}_{2} \mathrm{CH}_{2} \mathrm{CO}_{2} \mathrm{H}\right)\left(\mathrm{O}_{2} \mathrm{CCH}_{2} \mathrm{CH}_{2} \mathrm{CONH}-\mathrm{PEG}\right.\right.$-folate)] (Fig. 10 (C)) to the surface of an amine-functionalised single-walled carbon nanotube (SWNT) via multiple amide bonds to yield c,c-t-[Pt( $\left(\mathrm{NH}_{3}\right)_{2} \mathrm{Cl}_{2}\left(\mathrm{O}_{2} \mathrm{CCH}_{2} \mathrm{CH}_{2} \mathrm{CONH}-\mathrm{SWNT}\right)\left(\mathrm{O}_{2} \mathrm{CCH}_{2} \mathrm{CH}_{2} \mathrm{CONH}-\mathrm{PEG}\right.$-folate)].[190] The folate-PEG complex c,c-t-[Pt( $\left(\mathrm{NH}_{3}\right)_{2} \mathrm{Cl}_{2}\left(\mathrm{O}_{2} \mathrm{CCH}_{2} \mathrm{CH}_{2} \mathrm{CO}_{2} \mathrm{H}\right)\left(\mathrm{O}_{2} \mathrm{CCH}_{2} \mathrm{CH}_{2} \mathrm{CONH}-\mathrm{PEG}\right.$-folate)] was shown to preferentially target $\mathrm{FR}+\mathrm{ve}$ (human nasopharyngeal carcinoma $\mathrm{KB}$ ) over the FR-ve (testicular carcinoma NTera-2) cell lines. The cytotoxicity of $c, c-t-\left[\mathrm{Pt}\left(\mathrm{NH}_{3}\right)_{2} \mathrm{Cl}_{2}\left(\mathrm{O}_{2} \mathrm{CCH}_{2} \mathrm{CH}_{2} \mathrm{CO}_{2} \mathrm{H}\right)\left(\mathrm{O}_{2} \mathrm{CCH}_{2} \mathrm{CH}_{2} \mathrm{CONH}-\mathrm{PEG}\right.\right.$-folate)] was significantly enhanced when it was tethered to the SWNT ( $\mathrm{IC}_{50}$ improved from 0.15 to $0.01 \mu \mathrm{M}$ in the $\mathrm{KB}$ cells), which facilitates its delivery via folate receptor mediated endocytosis (FRME). The FRME mode of cell internalisation was confirmed when a fluorescein-based fluorophore was attached to $c, c-t-\left[\mathrm{Pt}\left(\mathrm{NH}_{3}\right)_{2} \mathrm{Cl}_{2}\left(\mathrm{O}_{2} \mathrm{CCH}_{2} \mathrm{CH}_{2} \mathrm{CONH}-\mathrm{SWNT}\right)\left(\mathrm{O}_{2} \mathrm{CCH}_{2} \mathrm{CH}_{2} \mathrm{CONH}-\right.\right.$ PEG-folate)], with the florescent derivative being observed inside the endosomes using fluorescence microscopy. Once the c,c-t-[Pt( $\left(\mathrm{NH}_{3}\right)_{2} \mathrm{Cl}_{2}\left(\mathrm{O}_{2} \mathrm{CCH}_{2} \mathrm{CH}_{2} \mathrm{CONH}-\mathrm{SWNT}\right)\left(\mathrm{O}_{2} \mathrm{CCH}_{2} \mathrm{CH}_{2} \mathrm{CONH}\right.$-PEG-folate)] enters the cell it is reduced to deliver the $\mathrm{Pt}(\mathrm{II})$ drug cisplatin $\left[\mathrm{Pt}\left(\mathrm{NH}_{3}\right)_{2} \mathrm{Cl}_{2}\right]$, thus avoiding the complications normally associated with the delivery of cisplatin under clinical conditions, and also with the added advantage of increasing the amount of cisplatin delivered into the cell. The release of the active cisplatin inside the cell was confirmed by the observation that Pt-1,2-d(GpG) intrastrand cross-links were formed with the nuclear DNA in KB cells. The c,c-t[Pt $\left(\mathrm{NH}_{3}\right)_{2} \mathrm{Cl}_{2}\left(\mathrm{O}_{2} \mathrm{CCH}_{2} \mathrm{CH}_{2} \mathrm{CONH}-\mathrm{SWNT}\right)\left(\mathrm{O}_{2} \mathrm{CCH}_{2} \mathrm{CH}_{2} \mathrm{CONH}\right.$-PEG-folate)] was found to be 8.6 times more active against FR+ve (human choriocarcinoma JAR and human nasopharyngeal carcinoma KB cell lines) than the FR-ve testicular carcinoma NTera-2 cell line. Although the concept of tethering FR-targeted conjugates to SWNT's to 
increase their cellular uptake is very interesting the toxicity of SWNT's is an issue that needs to be considered in any clinical applications.[195]

\subsection{Non-platinum systems}

The anticancer properties of gallium(III) compounds have been attracting attention since the 1970's. The mechanism through which Ga(III) induces cell death (involving DNA binding/modification, enzyme inhibition and ion transport disruption) has been extensively investigated however the pharmokinetic properties of gallium salts prevent their widespread chemotherapeutic use, some of which include renal retention time and cancer cell targeting. To explore the cancer cell targeting abilities of gallium(III) complexes, Viola-Villegas et al studied the conjugation of the gallium(III) complexes of 1,4,7,10-tetraazacyclododecane-1,4,7,10-tetraacetic acid (DOTA), via a polyethylene glycol (PEG) linker, to the $\gamma$ carboxylic acid moiety of folic acid (Fig. 11 (A)).[196] The authors determined the IC $_{50}$ concentrations for the Gallium(III) containing compounds in both A2780/AD (Adriamycin resistant ovarian cancer cell line which overexpresses FR) and $\mathrm{CHO}$ cells (non FR-expressing cell line), with the $\mathrm{IC}_{50}$ being lower in the A2780/AD cells in all cases. These studies revealed two interesting results; (i) the metal-free conjugate and its gallium complex were both toxic towards the CHO cells and (ii) the metal-free $\gamma$-FA-PEG-HDOTA showed greater cytotoxicity ( $\mathrm{IC}_{50}=1.35$ and $0.18 \mathrm{mM}$ for the $\mathrm{CHO}$ and $\mathrm{A} 2780 / \mathrm{AD}$ cell lines, respectively) than its coordinated counterpart, $\gamma$-FA-PEG-Ga(HDOTA) ((IC50 = 2.93 and $1.85 \mathrm{mM}$ for the $\mathrm{CHO}$ and A2780/AD cell lines, respectively). To explain this unexpected toxicity, researchers concluded that gallium was 'leaking' from the Ga-DOTA moiety, allowing the ligand to chelate other metals in the cellular environment. Additional stability studies carried out in HEPES buffer and RPMI 1640 media over 72 hours coupled with HPLC and ICP techniques supported this theory. Unfortunately, as the non-complexed $\gamma$-FA-PEG-(HDOTA) showed greater cytotoxicity than its gallium-containing counterpart, the folate conjugate $\gamma$-FA-PEG-Ga(HDOTA) was considered to be unsuitable as an anti-cancer agent. However, the authors did indicate that by coupling the $\gamma$-emitting ${ }^{67} \mathrm{Ga}$ isotope or $\beta$-emitting ${ }^{68} \mathrm{Ga}$ isotope to the FAPEG conjugate, it may be possible to use this approach to generate a suitable diagnostic agent.

The water-soluble folate conjugate of zinc tetraaminophthalocyanine (ZnaPc-folate) was recently reported (Fig. 11 (B)).[197, 198] The study of the photophysical and photochemical properties of ZnaPc-folate revealed that an increase in the fluorescence quantum yield of the conjugate was accompanied by a decrease in the triplet and singlet oxygen quantum yields, a decrease that was not observed when ZnaPc was simply mixed with folic acid (in the absence of formal conjugation).[197] Confocal laser scanning microscopy (CLSM) was employed to determine that ZnaPcfolate was significantly internalised in the FR+ve KB cell line when compared to the FR-ve A549 cells, and the results from competitive binding studies using folic acid pointed a FRME cellular uptake mechanism.[198] Whereas, ZnaPcfolate was found to be effectively inactive against KB cells in the absence of any photo-iradiation, irradiation with two-photon excitation (TPE) of near-infrared (NIR) laser pulses caused a 10-fold decrease in cell viability when compared to the results for sulphonated aluminium phthalocyanine (AlPcS), an approved photosensitizer for clinical 
applications under common one-photon excitation of red light.[198] The authors suggest that ZnaPc-folate represents a promising new generation of photosentizers for TPE-based photo-dynamic therapy (PDT).

(A)

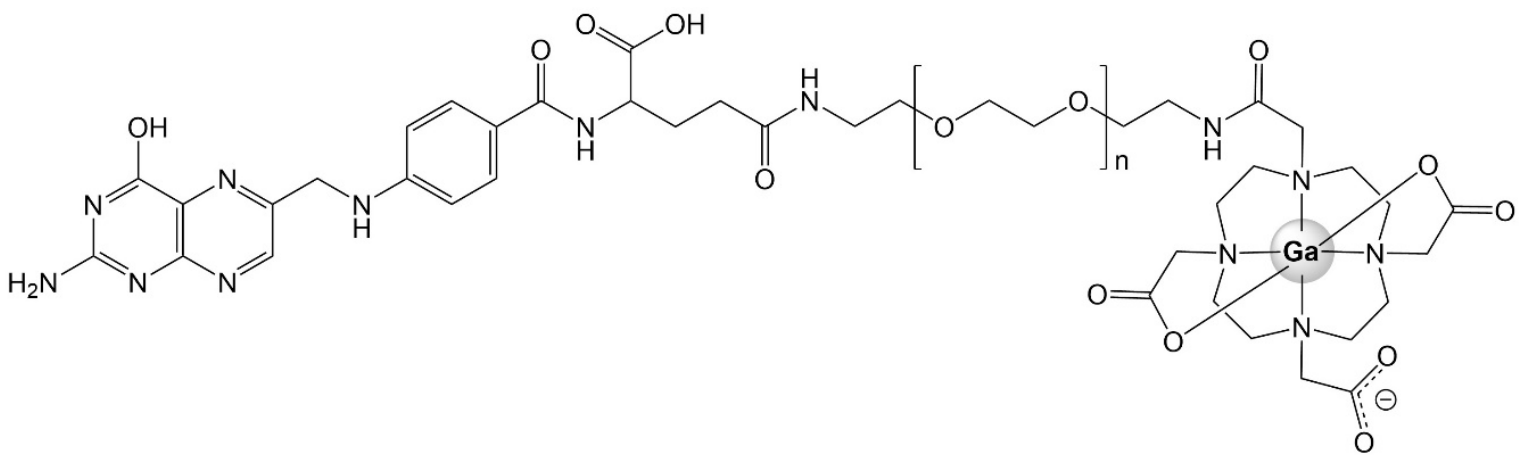

(B)

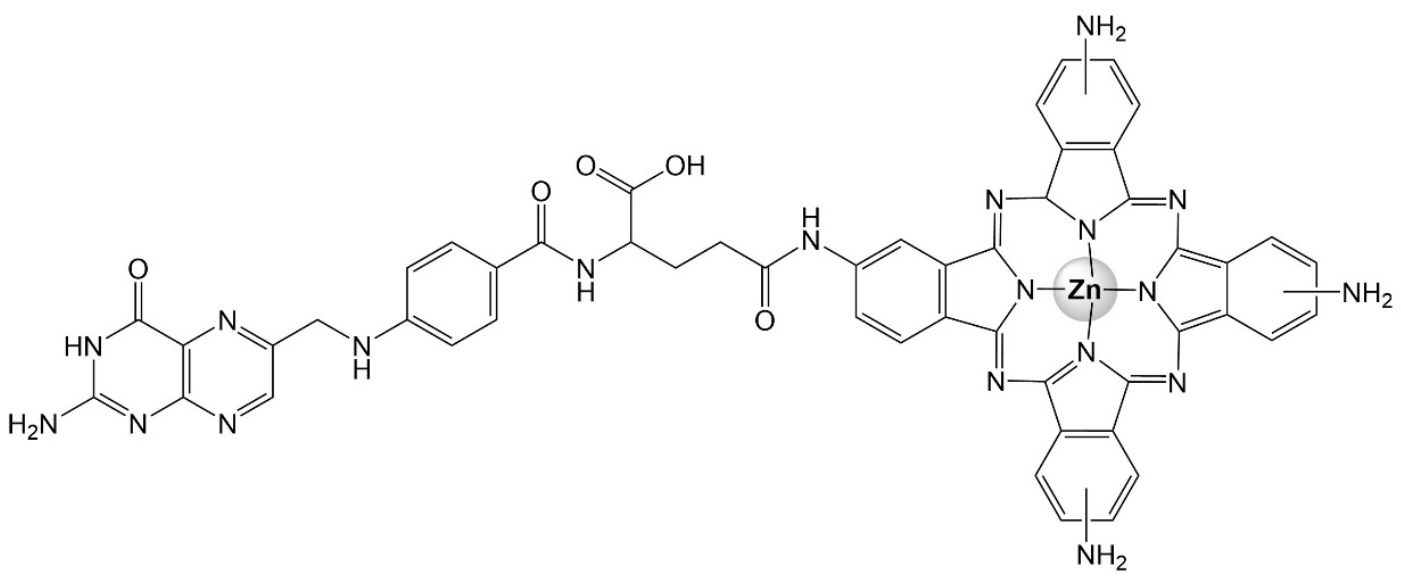

Fig. 11. (A) The proposed structure of gallium(III) complexes coordinated via DOTA and a polyethylene glycol linker to the $\gamma$ carboxylic acid moiety of folic acid, $\gamma$-FA-PEG-Ga(HDOTA) synthesized by Viola-Villegas, Vortherms and Doyle. $($ FA = Folic acid, PEG = Polyethylene glycol, DOTA = 1,4,7,10-tetraazacyclododecane-1,4,7,10-tetraacetic acid).[196] (B) Proposed structure of the water-soluble folate conjugate of zinc tetraaminophthalocyanine (ZnaPcfolate) or ZnTAPcFA.[197]

In 2015, Gou and colleagues explored the use of a folate-functionalised human serum albumin (FA-HSA) carrier system as a FR targeted delivery system for copper(II) complexes incorporating plumbagin, bypyridine and 1,10-phenanthroline ligands (Fig. 12).[199] Plumbagin is a natural small molecular naphthoquinone analogue isolated from the medicinal plant Plumbago zeylanica and which exhibits moderate anticancer activities in vitro and in vivo.[200-202] The FA-HAS-Cu complex systems were generated by incubating the copper(II) complexes with the FA-HSA conjugate in BPS media and DMSO (0.5\%) and the binding of the complexes, which is believed to occur in the subdomain IIA of the protein, was confirmed by measuring fluorescence quenching associated with the HSA. The 
binding constants for the FA-HSA to the copper(II) complexes $\left(K \sim 10^{5} \mathrm{M}^{-1}\right)$ is relatively low and the authors pointed out that this was a potential weakness with respect to the efficiency of the delivery of the complexes.<smiles>Cc1cc(=O)c2c(Oc3cccc4c3C(=O)OC(C)C4)cccc2o1</smiles>

1

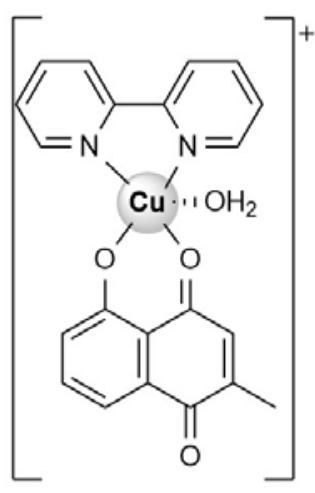

2

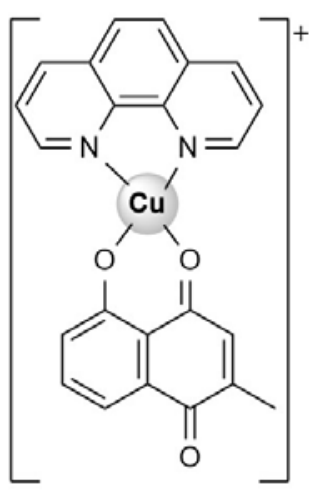

3

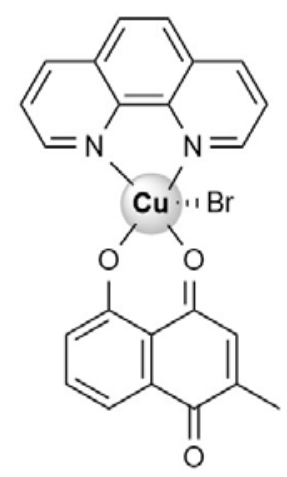

4

Fig. 12. Structures of various $\mathrm{Cu}(\mathrm{II})$ plumbagin polypyridyl complexes investigated by Gou et al.[199] Adapted from Gou et al.[199]

To determine the FR specific cytotoxicity of the complexes, a number of mammalian cell lines were used (FR+ve cell lines, HeLa and MCF-7 and FR-ve cell line WI-38). Whereas, the Cu(II) complexes themselves were equally cytotoxic towards the FR+ve and FR-ve cells lines (IC50 range $=3-8 \mu \mathrm{M}$ ) the FA-HSA-copper complex systems were approximately three times more active against the FR+ve cells $\left(\mathrm{IC}_{50}\right.$ range $\left.=0.98-3.67 \mu \mathrm{M}\right)$ than the FR-ve cell line $\left(\mathrm{IC}_{50}\right.$ range $\left.=3.95-6.95\right) \mu \mathrm{M}$. The FA-HSA-copper complex system incorporating the $[\mathrm{Cu}$ (PLN)(phen) $]^{+}$(where PLN = the plumbagin anion, (Fig 12 (3)) was the most cytotoxic and further studies revealed that in HeLa cells it caused mitochondrial damage through production of reactive oxygen species (ROS) and inhibited the activity of cyclin-dependent kinase-1 (CDK1) and the prosurvival Bcl-2 proteins leading to apoptotic cell death.

The targeted therapeutic properties of the relatively few non-platinum folate-metal complex conjugates discussed have been summarized in Table 3 .

\section{FOLATE-METAL COMPLEX CONJUGATES AS TARGETED DIAGNOSTIC AGENTS}

The advent of theranostic systems, containing a targeted drug coupled to an imaging agent, has been a key development in modern medicine, particularly in the treatment of cancer. This advancement would not have materialised if it were not for the significant successes achieved in the fields of molecular imaging and in the expansion of the knowledge-base of the synthesis of efficient targeting compounds.[203] 
The deployment of luminescent metal complexes offers an appealing capability for cell imaging because of the specific properties of luminescence emission from the excited states of the metals.[204] Lanthanides, Europium in particular, have luminescent properties when bound to organic, chelating ligands. In addition, europium offers an array of advantages such as exhibiting long emission times, enabling time-resolved measurements while narrow, intense absorption bands ensure high colour purity. Luminescent lanthanide complexes (LLC) such as europium complexes offer increased loading capabilities as they do not exhibit the self-quenching properties that are often observed for organic dyes. Various LLCs can be generated from the same ligand and can thus be excited by the same wavelength. Furthermore, the complexes synthesised often show high chemical, thermal, kinetic and photo-physical stability while exhibiting low toxicity when compared to gadolinium complexes commonly used as contrast agents in magnetic resonance imaging (MRI).[205] Therefore, it is unsurprising that they may prove to be highly sensitive luminescent probes in biomedical studies. Indeed, a series of effective luminescent europium(III) complexes exhibiting optical imaging capabilities for subcellular structures such as mitochondria, endoplasmic reticulum and lysosomes of a variety of mammalian cell lines, has recently been reported.[206] Reports of folate-targeted luminescent probes are scarce in the literature.

In 2012, Pavich et al synthesised the folic acid-europium chelate conjugate [FA-(phen)Eu(BTA) 3 ] (FA(phen) = Folate-spcer-1,10-phenanthroline conjugate; BTA = benzoyl trifluoroacetone) (Fig. 13 (A)).[207] In addition to completing studies of the absorption and luminescence spectra, as well as the luminescence excitation of the newly formed complex, the group conducted cellular uptake studies using the FR+ cell line, HeLa. Binding of the conjugate by the cells was determined from the intensity of europium luminescence in HeLa cell lysates. Cells were treated with the europium conjugate for 3 hours, washed in ice cold PBS and lysed in 0.1\% Triton X-100. Results indicated significant quantities of the europium conjugate ( $4 \mathrm{X} 10^{6}$ conjugate molecules per cell) per cell. However, the methodology used limits the interpretation as to whether the conjugate was internalised by the cells or whether it was bound to the cell surface. The addition of exogenous folic acid severely reduced the binding of the molecules by $68 \%$, suggesting that the folate receptor localized on the cell surface is binding to the conjugate.[207] These results and the observed promising luminescent timeframe of $110 \mu$ s may serve to spearhead the design of selective methods for timeresolved luminescent microanalysis based on conjugates of folic acid with europium complexes. However, the characterisation of the $\left[\mathrm{FA}-(\right.$ phen $\left.) \mathrm{Eu}(\mathrm{BTA})_{3}\right]$ was poor and no data regarding the cytotoxicity or stability of the conjugate were reported. 
(A)

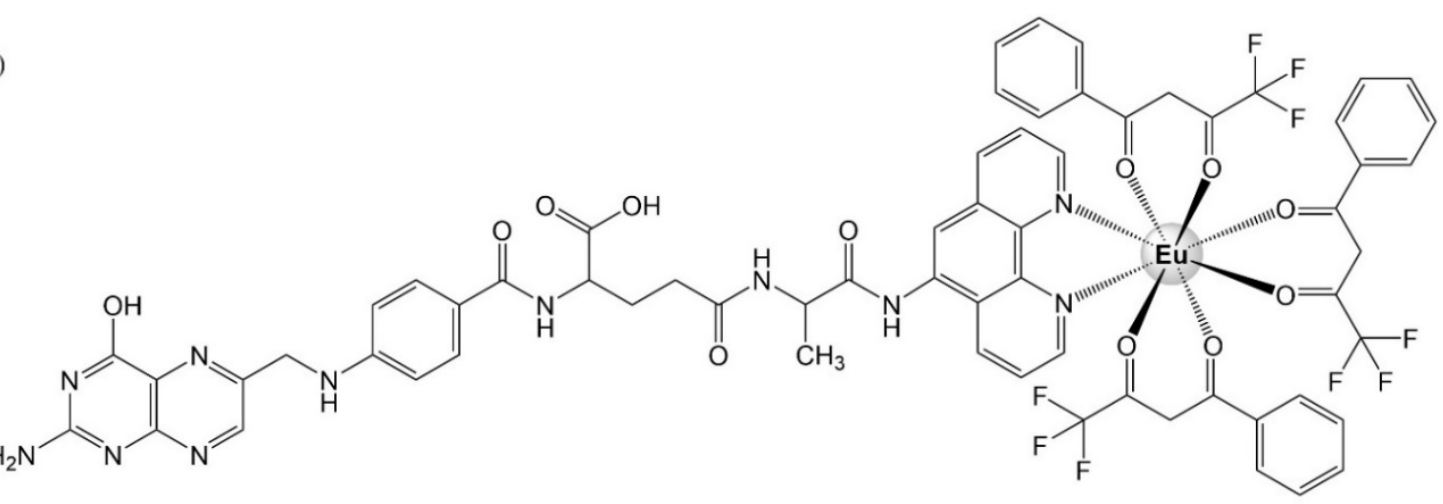

(B)

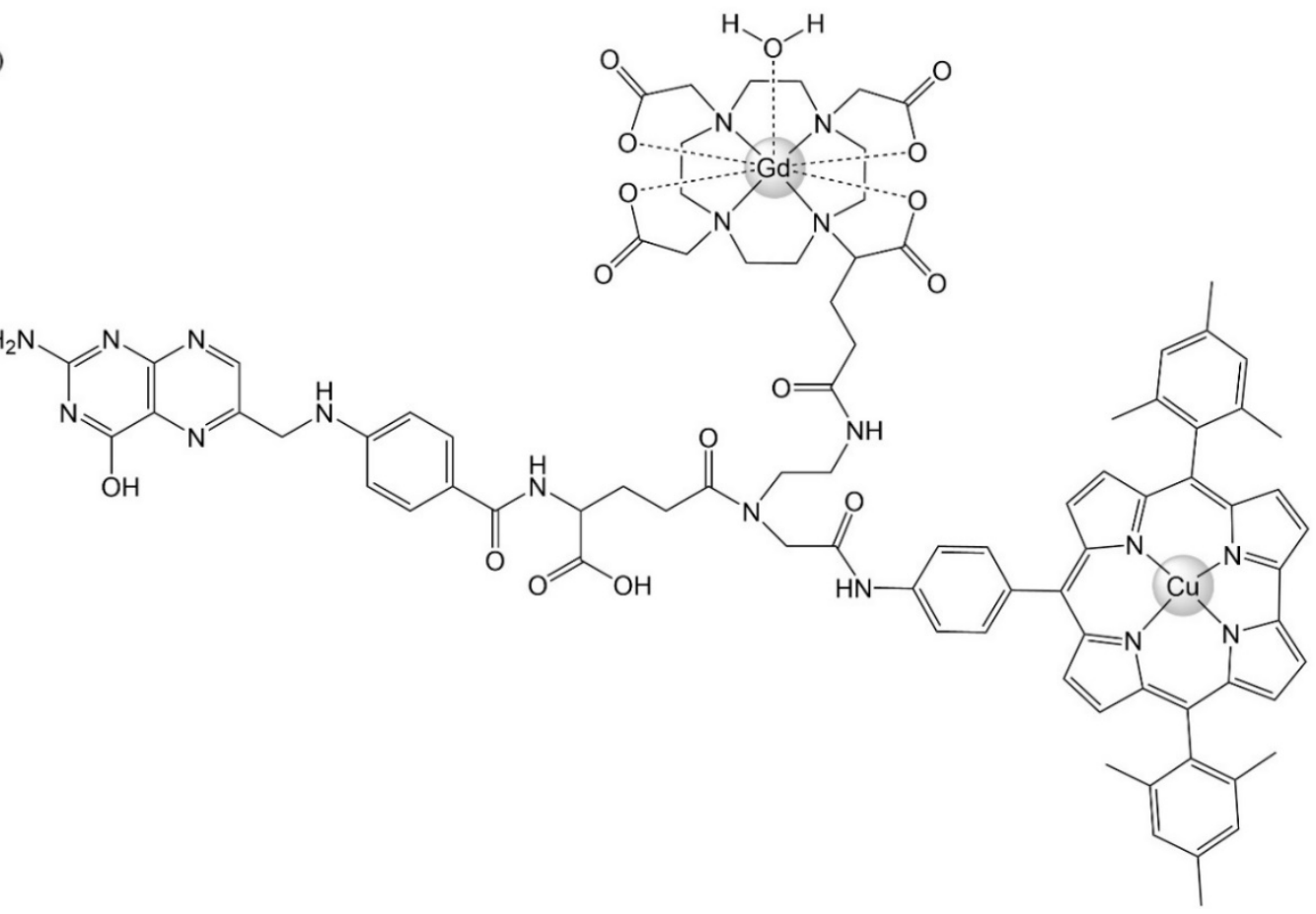

Fig. 13. (A) The structure of the conjugate FA-(Phen)Eu(BTA) $)_{3}$ (Phen = 1,10-Phenanthroline, BTA = benzoyl trifluoroacetone).[207] (B) Structure of the Cu corrole, Gd DOTA folate complex.[208]

The gadolinium(III) complex of DOTA is currently used as an extravascular contrast agent for MRI.[209] Recently, a number of bifunctional imaging contrast agents incorporating DOTA and porphyrin macrocycles have been reported.[210, 211] In 2015 Gros et al reported the synthesis and characterisation of a heterobimetallic copper(II) corrole/gadolinium(III) DOTA-folate complex (Fig. 13 (B)) as a potential FR-targeted bifunctional contrast agent for MRI and positron emission tomography (PET) imaging of cancer.[208] The complex was obtained in high yield by means of a five step synthesis. 


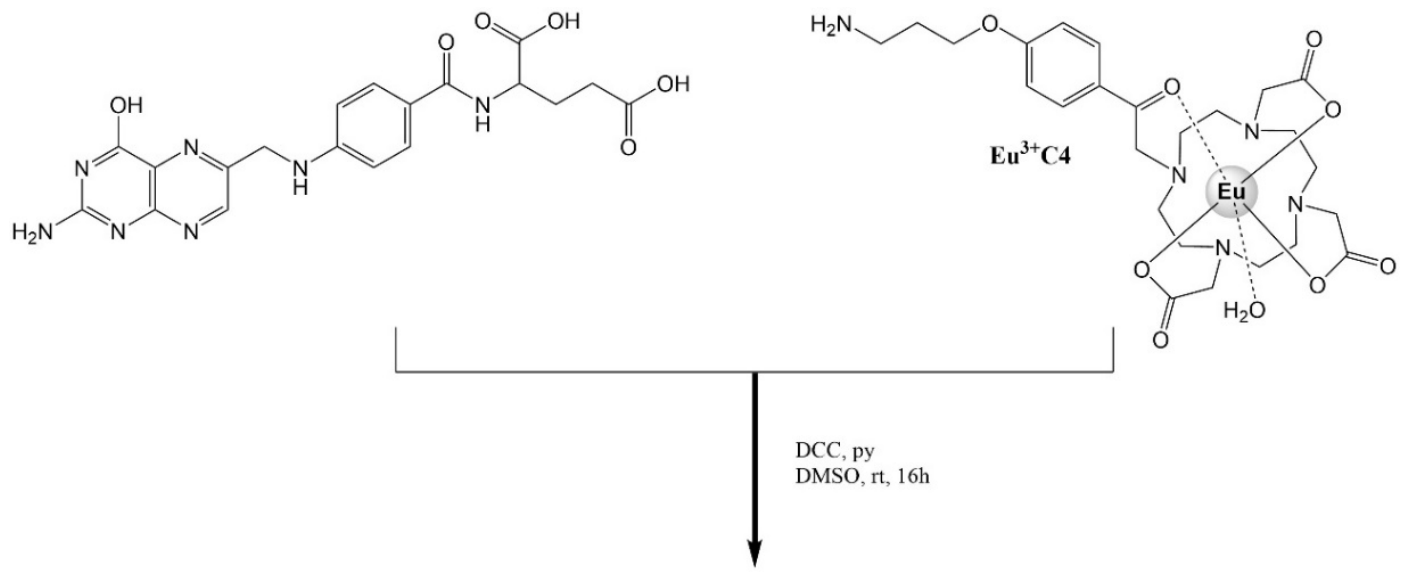

$\mathrm{Eu}^{3+} \mathrm{C} 1+\mathbf{E u}^{3+} \mathbf{C} 2$
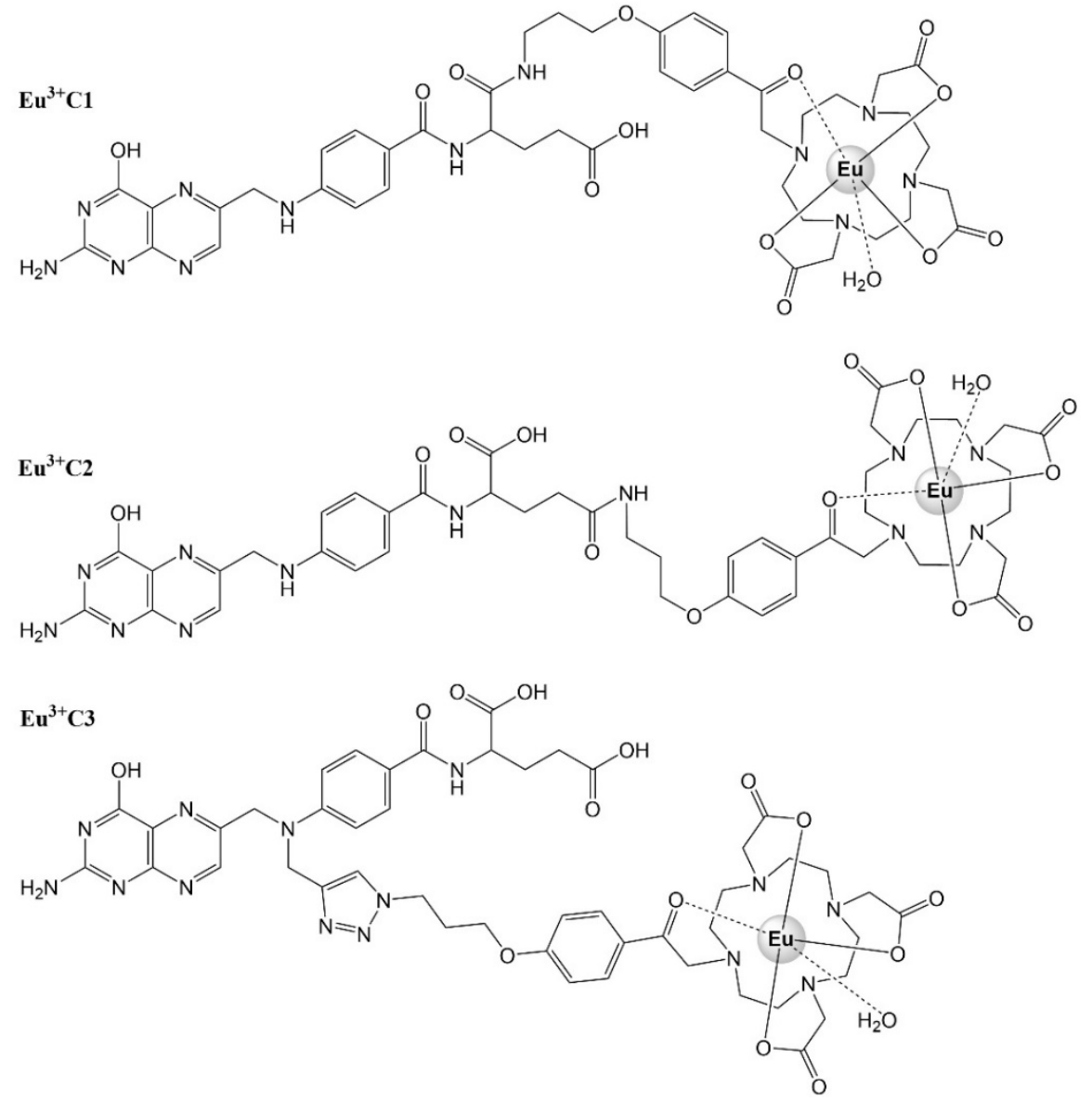

Fig. 14. Synthetic details and the structures of the three Europium complexes $\mathrm{Eu}^{3+} \mathrm{C} 1, \mathrm{Eu}^{3+} \mathrm{C} 2$ and $\mathrm{Eu}^{3+} \mathrm{C} 3$ coordinated via DOTA to various conjugation sites of folic acid (DCC = dicyclohexylcarbodiimide; py = pyridine; DMSO = dimethylsulphoxide; $\mathrm{Eu}^{3+} \mathrm{C} 4$ was synthesised as previously reported.[212] 
Preliminary studies showed that the relaxivity of the heterobimetallic copper(II) corrole/gadolinium(III) DOTA-folate complex was higher in comparison to the commercially available MRI contrast agent [Gd(DOTA) $\left.\left(\mathrm{H}_{2} \mathrm{O}\right)\right]$. The authors did not report any data for the toxicity, cellular uptake or FR specificity of the complex.

Also in 2015, Quici and colleagues reported the results of a more thorough study of the three water-soluble europium complexes conjugated via 1,4,7,10-Tetraazacyclododecane-1,4,7,10-tetraacetic acid (DOTA) to $\alpha$ carboxylate, the $\gamma$-carboxylate and N10 (the nitrogen of the para-aminobenzoic acid group) positions of folic acid (denoted $\mathrm{Eu}^{3+} \mathrm{C} 1, \mathrm{Eu}^{3+} \mathrm{C} 2, \mathrm{Eu}^{3+} \mathrm{C} 3$, respectively) as luminescent probes for the selective targeting of cancer cells (Fig. 14).[212] The $\alpha$ - and the $\gamma$-carboxylate conjugates $\mathrm{Eu}^{3+} \mathrm{C} 1$ and $\mathrm{Eu}^{3+} \mathrm{C} 2$ were generated, as a regioisomeric mixture, as shown in Fig. 14, they were separated as pure isomers by HPLC and identified by ESI mass spectrometry. $\mathrm{Eu}^{3+} \mathrm{C3}$ required a seven step synthesis and it was also obtained in a pure state. Synthesising one Eu complex ligated via the $\alpha$-carboxyl group of folic acid (complex $1, \mathrm{Eu}^{3+} \mathrm{C} 1$ ), one via the $\gamma$-carboxyl group (complex 2, $\mathrm{Eu}^{3+} \mathrm{C} 2$ ) and one via the nitrogen of the para-aminobenzoic acid group (complex 3, $\mathrm{Eu}^{3+} \mathrm{C} 3$ ) as depicted in Fig. 14. Stability studies on $\mathrm{Eu}^{3+} \mathrm{C} 1, \mathrm{Eu}^{3+} \mathrm{C} 2, \mathrm{Eu}^{3+} \mathrm{C} 3$ were conducted by incubating all three conjugates in phosphate buffered saline (PBS), cell culture medium and rat serum at $37^{\circ} \mathrm{C}$ for $25 \mathrm{hr}$ and revealed that varying media did not affect either conjugate luminescence or spectral shape. Cytotoxicity assays and internalisation studies conducted on a range of FR+ve ovarian cancer cell lines indicated that all three conjugates were only cytotoxic at concentrations above $300 \mu \mathrm{M}$ and that internalisation was both concentration and time dependent. A negative test with the FR-ve cell line A2780 showed no internalisation, indicating that the uptake was folate receptor mediated. Furthermore, all three conjugates complexes $\mathrm{Eu}^{3+} \mathrm{C} 1, \mathrm{Eu}^{3+} \mathrm{C} 2, \mathrm{Eu}^{3+} \mathrm{C} 3$ were found to be extremely stable over time and after cell exposure and internalisation, with no apparent biotransformation and no significant interaction occuring with serum protein.

Acknowledging recent discoveries regarding the FR binding site and the importance of the pterin head in receptor recognition as well as literature disputing the need for a free $\alpha$-carboxyl group for adequate receptor binding, the group also studied the relationship between conjugation site and recognition capabilities of the conjugates by the FR. [80, 213, 214] The cellular uptake of $\mathrm{Eu}^{3+} \mathrm{C} 1, \mathrm{Eu}^{3+} \mathrm{C} 2, \mathrm{Eu}^{3+} \mathrm{C} 3$ was found to be receptor dependent with correlation between the uptake and FR expression. The conjugation site was also found to be a critical factor with the binding affinity following the order $\mathrm{Eu}^{3+} \mathrm{C} 2>\mathrm{Eu}^{3+} \mathrm{C} 1>\mathrm{Eu}^{3+} \mathrm{C} 3$ in the SKOV-3 cell line, highlighting the importance of the pterin head and para-aminobenzoic acid body of folic acid in receptor recognition. Furthermore, both folic acid and $\mathrm{Eu}^{3+} \mathrm{C} 2$ were found to have equal ability to inhibit the binding of radio-labelled folic acid.

In another recent study Plush et al examined the influence that the length of the linker between the folate head and the lanthanide-DOTA chelate had on FR mediated uptake.[215] They synthesised and characterised watersoluble folate-targeted lanthnide probes ( $\mathrm{Ln}(\mathrm{III})=\mathrm{Eu}(\mathrm{III}), \mathrm{Tb}(\mathrm{III})$ or $\mathrm{Gd}(\mathrm{III})$ ) in which the $\mathrm{Ln}(\mathrm{DOTA})$ moieties were connected to the folate heads via an aliphatic $\left(-\mathrm{CH}_{2}-\right)_{n}$ chain (where $n=1$ or 5) (Fig. 15). 


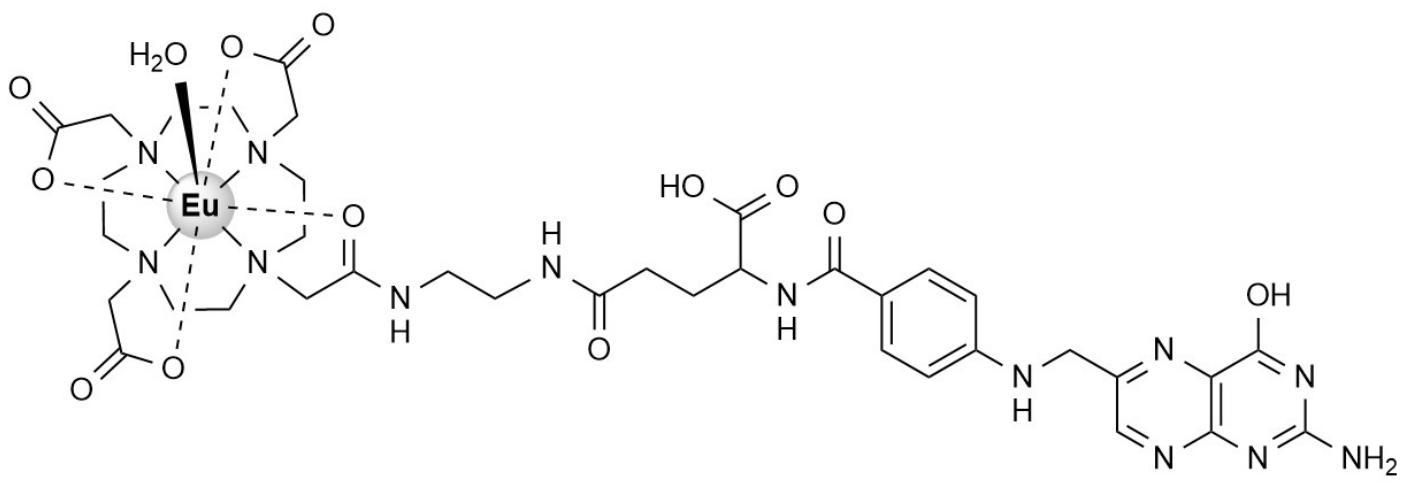

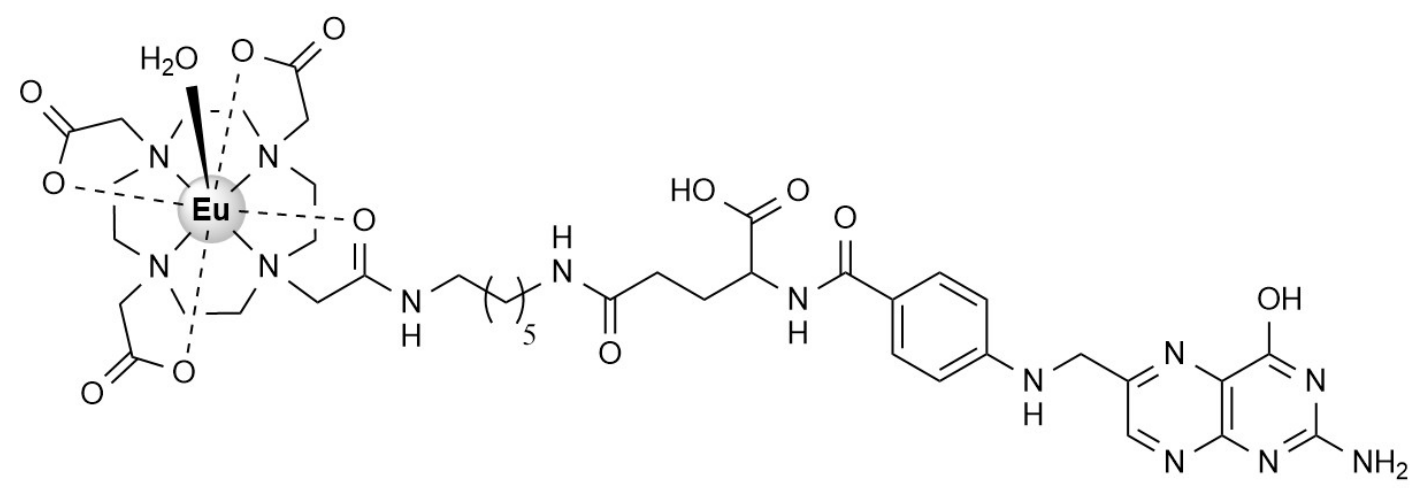

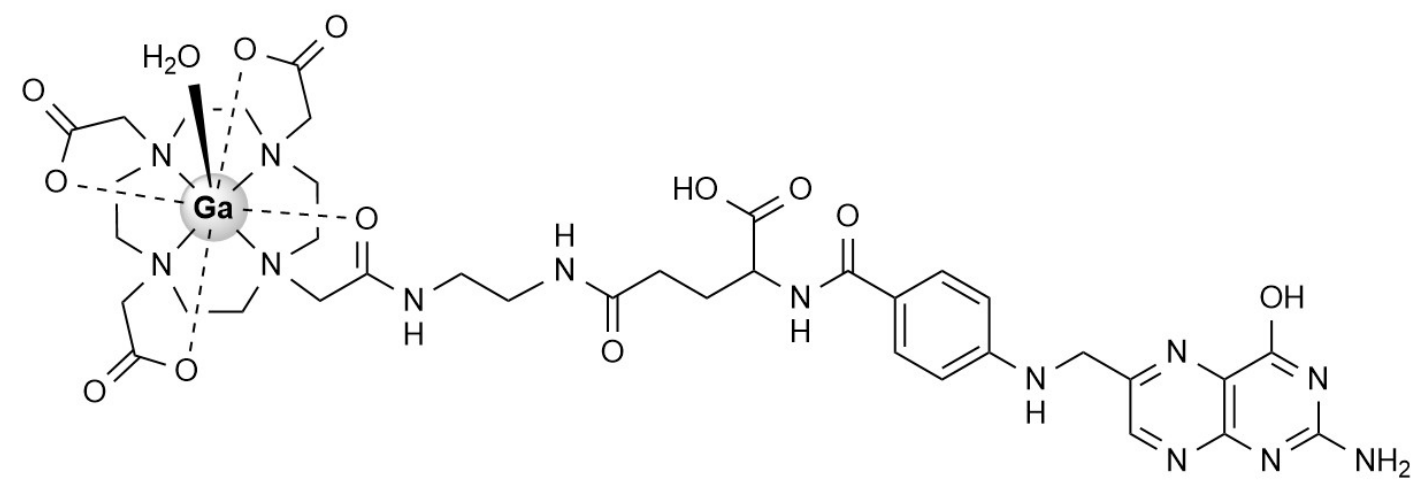

Fig. 15. Structures of the water-soluble folate-targeted lanthnide probes $(\mathrm{Ln}(\mathrm{III})=\mathrm{Eu}(\mathrm{III})$ or $\mathrm{Gd}(\mathrm{III}))$ in which the $\mathrm{Ln}\left(\right.$ DOTA) moieties were connected to the folate heads via an aliphatic $\left(-\mathrm{CH}_{2}-\right)_{n}$ chain (where $\mathrm{n}=1$ or 5).[215]

Dual action imaging agents are currently attracting significant attention.[216, 217] In 2011 Yang et al reported the facile synthesis of the water-soluble terbium(III)DTPA-folate- $\mathrm{Fe}_{3} \mathrm{O}_{4}$ nanoparticle conjugates (denoted as Tb:1b-FA-NP's) (Fig. 16) (DTPAH (D $_{3}$ diethylenetriaminepentaacetic acid; and the linkers between the TB;1b and NP moieties are polyethyleneglycol chains (PEG's).[218] 


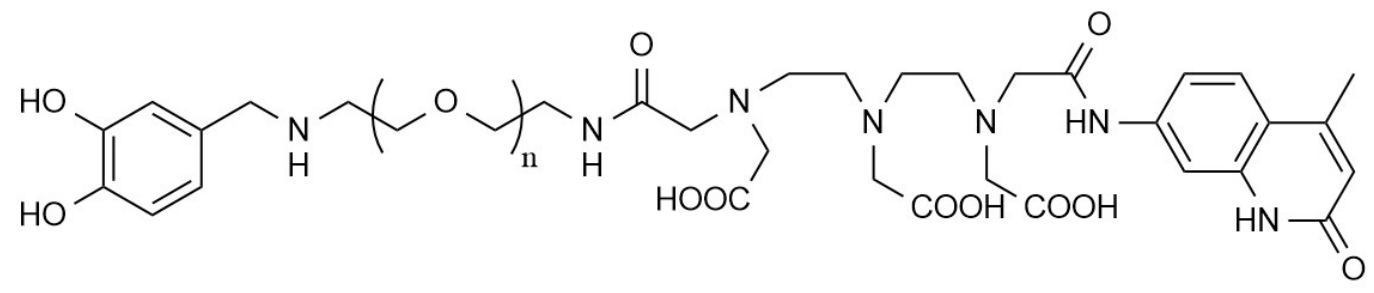

1b<smiles>Nc1nc2ncc(CNc3ccc(C(=O)NC(CCC(=O)Nc4ccc(O)c(C(=O)O)c4)C(=O)O)cc3)nc2c(=O)[nH]1</smiles>

2-hydroxybenzoic acid-FA derivative

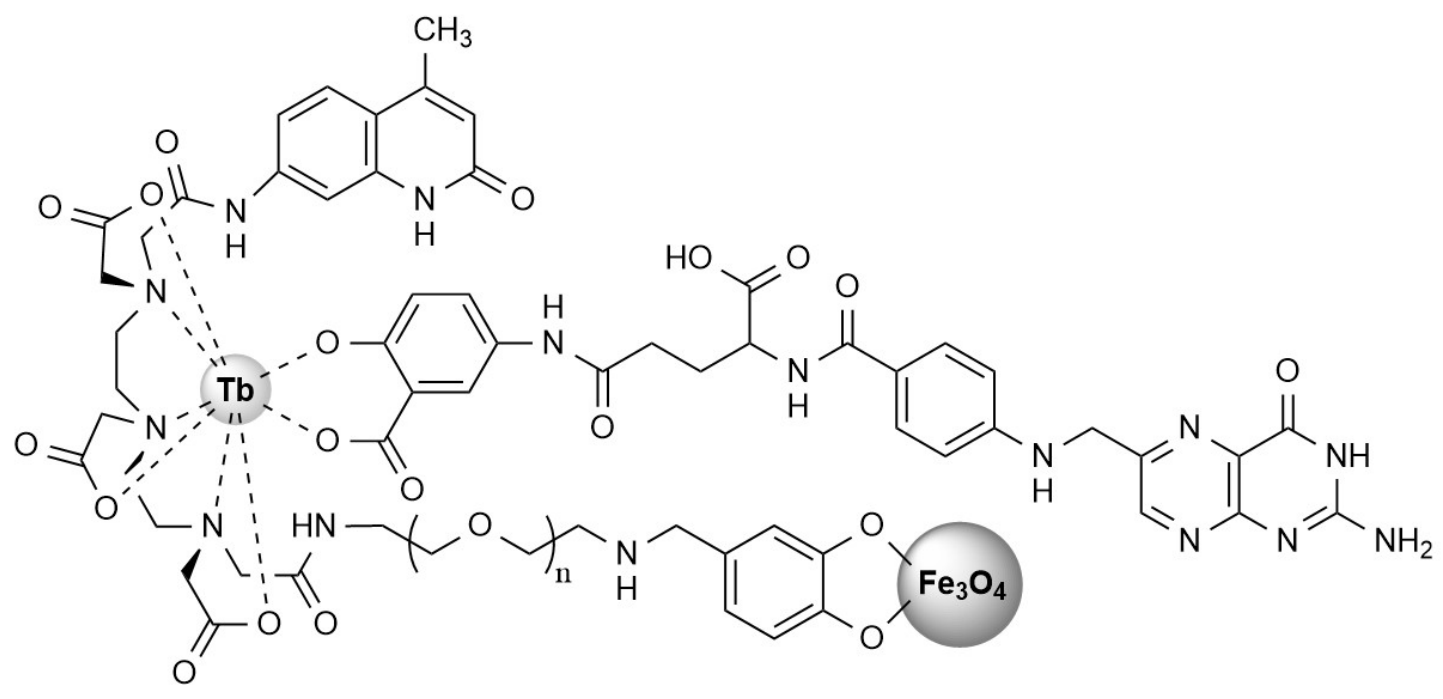

Tb:1b-FA-NPs

Fig. 16. Structure of a terbium(III) complex, Tb:1b-FA-NPs coupled to $\mathrm{Fe}_{3} \mathrm{O}_{4}$ magnetic nanoparticles and ligands $1 \mathrm{~b}$ and a 2-hydroxybenzoate derivative of Folic acid.[218]

Tb:1b-FA-NP's were strongly luminescent in aqueous solution and they have a long fluorescence lifetime. Cellular uptake studies, using confocal microscopy, on FR+ve Hela and FR-ve MCF-7 cells revealed that the conjugates were preferentially taken up by the FR expressing HeLa cells in-vitro. Tb:1B-FA-NP's was non-toxic to the HeLa cells (up to $160 \mu \mathrm{M}$ ) and they also exhibited superparamagnetic properties upon entering the HeLa cells 
where they were shown to provide significant contrast enhancement in magnetic resonance imaging (MRI) images. The authors propose that this class of Tb:1B-FA-NP's have potential applications as agents for both fluorescence cell imaging and MRI.

Along with PET, single photon emission computed tomography (SPECT) is another highly sensitive cancer imaging technique which has attracted significant interest in the development of folate-based tracers to target FR expressing cancers, an area that has been previously reviewed.[219-221] For the development of folate-conjugates of such nuclear imaging agents ${ }^{99 \mathrm{~m}} \mathrm{Tc}$ has emerged as the preferred radionuclide for applications in SPECT. One of the best studied examples of such FR-targeted technecium radionuclides in ${ }^{99 \mathrm{~m}} \mathrm{Tc}-\mathrm{EC} 20$ in which ${ }^{99 \mathrm{~m}} \mathrm{Tc}(\mathrm{V})$ is complexed to a peptide (Cys-Asp-Dap-D-Glu-Pte) which is linked to a folate moiety (Fig. 17 (A)).[128] ${ }^{99 m}$ Tc-EC20 was found to be an excellent imaging agent, with very high tumour uptake in a mouse model and the results were similar when it was screened in clinical trials.[127] The study found that a single intravenous injection of ${ }^{99 m}$ Tc-EC20 resulted in detectable uptake (measured using planar scintigraphy or SPECT) in $68 \%$ of patients and was well tolerated by the adult patients tested. Consequently, the authors suggested that ${ }^{99 \mathrm{~m}}$ Tc-EC20 imaging was a safe, non-invasive procedure that may identify FRs in recurrent or metastatic disease without the need for biopsy.[127]

(A)<smiles>Nc1nc(O)c2nc(CNc3ccc(C(=O)NC(CCC(=O)NCC4NC5(Cl)SCC(C(=O)O)N5C(=O)C4CC(O)O)C(=O)O)cc3)cnc2n1</smiles>

(B)<smiles>COCCN1CCP(c2ccccc2)C12CCP(c1ccccc1)(c1ccccc1)(c1ccccc1)C21OC(=O)C(NC(=O)CCC(NC(=O)c2ccc(NCc3cnc4nc(N)nc(O)c4n3)cc2)C(=O)O)CS1</smiles>

Fig. 17. (A) Structure of folic acid radioconjugate, ${ }^{99 \mathrm{~m}} \mathrm{Tc}-\mathrm{EC} 20 .[128]$ (B) Structure of a new ${ }^{99 \mathrm{~m}} \mathrm{Tc}-\mathrm{folic}$ acid radiotracer prepared using $\left[{ }^{99 \mathrm{~m}} \mathrm{TcN}(\mathrm{PNP})\right]^{2+}$ metal fragment.[222] 
However, accumulation of ${ }^{99 \mathrm{~m}}$ Tc-EC20 in the kidneys and bladder, due to the presence of high FR expression in these tissues, caused problems with very significant renal uptake of radioactivity. This problem can be ameliorated to a significant extent by pre-treatment with antifolates such as pemetrexed.[223] However, this strategy is not ideal as it exposes diseased patients to further stress. In recent years there have been several attempts to improve the efficacy of ${ }^{99 \mathrm{~m}}$ Tc-labeled folate conjugates by modifying the nature of the linkers, the chelating agents and the radiosynthon but the problem with high accumulation in the kidneys has persisted due to the highly hydrophobic nature of the ${ }^{99 \mathrm{~m}}$ Tclabeled folate conjugates.[224, 225] In 2017 Banerjee et al reported the synthesis and biological evaluation of a ${ }^{99 \mathrm{~m}}$ Tc-labeled folate conjugate with the lipophilic $\left[{ }^{99 \mathrm{~m}} \mathrm{TcN}(\mathrm{PNP})\right]^{2+}$ inorganic moiety [where $\mathrm{N}(\mathrm{PNP})=\mathrm{N}-$ (2methoxyethyl)-2-(diphenylphosphino)-N-(2-diphenylphosphino)ethyethanamine\} (Fig. 17 (B)).[222] The ${ }^{99 m}$ Tclabeled folate conjugate was constructed by attaching a cysteine-based (O-S) bifunctional chelating group to the $\gamma$ carboxylic acid function of folic acid to yield the targeted vector, which in turn acts as a O-S chelate upon complexation with $\left[{ }^{99 \mathrm{~m}} \mathrm{TcN}(\mathrm{PNP})\right]^{2+}$, yielding the $\left[{ }^{99 \mathrm{~m}} \mathrm{TcN}(\mathrm{PNP})\right]^{2+}$-folate conjugate (Fig. 17 (B)). The $\left.{ }^{[99 \mathrm{~m}} \mathrm{TcN}(\mathrm{PNP})\right]^{2+}$-folate conjugate was found to be significantly lipophilic $\left(\log \mathrm{P}_{\mathrm{o} / \mathrm{w}}=0.87\right)$. In vitro studies on FR expressing KB-31 cells unfortunately revealed that this new ${ }^{99 m}$ Tc-labeled folate conjugate had less affinity (approximately 10-fold) for the FR than native folic acid. However, in vivo studies involving normal Swiss mice revealed that the $\left[{ }^{99 m} \mathrm{TcN}(\mathrm{PNP})\right]^{2+}$-folate conjugate was effectively cleared from through the kidneys which is in itself a significant development. The authors propose that the inclusion of an appropriate aliphatic spacer in the structure of the $\left[{ }^{99 \mathrm{~m}} \mathrm{TcN}(\mathrm{PNP})\right]^{2+}$-folate conjugate as a possible route to improving the FR uptake of this class of potential radiotracer.

Table $\mathbf{4}$ summarises the structural and biological profiles for folate-metal complex conjugates with targeted diagnostic potential. 
Table 2: The structural and biological profiles for FR targeted platinum anticancer conjugates.

\begin{tabular}{|c|c|c|c|c|c|c|}
\hline \multicolumn{7}{|c|}{ FR Targeted Platinum-Based Anticancer Conjugates } \\
\hline Conjugate type & Linker & Active Component & $\begin{array}{l}\text { Cellular Uptake } \\
\text { studies }\end{array}$ & In-Vitro Activity & In-Vivo Activity & Ref. \\
\hline Folate-cisplatin & aliphatic diamine & Cisplatin & None reported & None reported & None reported & {$[186]$} \\
\hline Folate-carboplatin & aliphatic amine & Carboplatin & & & & \\
\hline Folate-PEG-carboplatin & polyethyleneglycol & Carboplatin & $\begin{array}{l}\text { Confirmed by } \\
\text { confocal } \\
\text { microscopy and } \\
\text { FACS }\end{array}$ & $\begin{array}{l}\text { Reduced } \\
\text { cytotoxicity in } \\
\text { FR+ve M109HiFR } \\
\text { cell line when } \\
\text { compared to non- } \\
\text { targeted analogue. }\end{array}$ & None reported & [188] \\
\hline $\begin{array}{l}\text { Cisplatin-folate-PEG- } g \text {-PAsp- } \\
\text { Ami micelles }\end{array}$ & $\begin{array}{l}\text { PEG-graft- } \alpha, \beta \text {-poly }[(\mathrm{N}- \\
\text { amino } \\
\text { aspartamide }]\end{array}$ & Cisplatin & $\begin{array}{l}\text { Confirmed by } \\
\text { cytotoxicity assays } \\
\text { in presence of } \\
\text { excess folic acid }\end{array}$ & $\begin{array}{l}\text { Superior } \\
\text { cytotoxicity } \\
\text { compared to non- } \\
\text { targeted Cisplatin- } \\
\text { PEG-g-PAsp-Ami } \\
\text { micelles in FR+ve } \\
\text { KB cell line. }\end{array}$ & $\begin{array}{l}\text { Athymic mice: } \\
\text { similar results to } \\
\text { in vitro study with } \\
\text { low toxicity. }\end{array}$ & {$[189]$} \\
\hline Carboplatin-folate-liposome & $\begin{array}{l}\text { None: folate coupled } \\
\text { directly to the liposome }\end{array}$ & Carboplatin & $\begin{array}{l}\text { Confirmed using } \\
\text { IGROV-1 cells (2- } \\
\text { fold increase in } \\
\text { cellular } \\
\text { accumulation } \\
\text { compared to } \\
\text { carboplatin) }\end{array}$ & $\begin{array}{l}\text { 2-fold increase in } \\
\text { cytotoxicity in } \\
\text { IGROV-1 cells } \\
\text { compared to } \\
\text { carboplatin }\end{array}$ & $\begin{array}{l}\text { IGROV-1 ovarian } \\
\text { tumour xenograft } \\
\text { mice: Low } \\
\text { toxicity and } \\
\text { increased survival } \\
\text { rate (83\%) } \\
\text { compared to } \\
\text { carboplatin }\end{array}$ & {$[191]$} \\
\hline $\begin{array}{l}{\left[\mathrm{As}(\mathrm{OH})_{3}\right] /\left[\mathrm{Pt}\left(\mathrm{NH}_{3}\right)_{2}\left(\mathrm{H}_{2} \mathrm{O}\right)_{2}\right]^{2+}} \\
\text {-folate-liposome }\end{array}$ & $\begin{array}{l}\text { None: folate coupled } \\
\text { directly to the liposome }\end{array}$ & $\begin{array}{l}{\left[\mathrm{As}(\mathrm{OH})_{3}\right] \text { and }} \\
{\left[\mathrm{Pt}\left(\mathrm{NH}_{3}\right)_{2}\left(\mathrm{H}_{2} \mathrm{O}\right)_{2}\right]^{2+}}\end{array}$ & $\begin{array}{l}\text { Preferential uptake } \\
\text { in FR+ve KB cells } \\
\text { when compared } \\
\text { with FR-ve MCF-7 }\end{array}$ & $\begin{array}{l}\text { Attenuated } \\
\text { cytotoxicity } \\
\text { towards FR+ve }\end{array}$ & None reported & {$[192]$} \\
\hline
\end{tabular}




$\begin{array}{lll}\text { Cisplatin-folate-nanogels } & \begin{array}{l}\text { None: folate coupled } \\ \text { directly to the nanogel }\end{array} & \text { Cisplatin } \\ & & \begin{array}{l}\text { in FR+ve A2780 } \\ \text { cells compared to }\end{array} \\ & \text { FR-ve A549 cells }\end{array}$

$\left[\mathrm{Pt}\left(\mathrm{NH}_{3}\right)_{2}\left(\mathrm{H}_{2} \mathrm{O}\right)_{2}\right]^{2+} /$ rhodamine $\mathrm{B}$ isothiocyanate- folate-

magnetic calcium phosphate

nanoparticles

$\begin{array}{ll}\text { c,c-t- } & \text { The } \\ {\left[\mathrm{Pt}\left(\mathrm{NH}_{3}\right)_{2} \mathrm{Cl}_{2}\left(\mathrm{O}_{2} \mathrm{CCH}_{2} \mathrm{CH}_{2} \mathrm{CO}\right.\right.} & \mathrm{Pt}\left(\mathrm{NH}_{3}\right)_{2} \mathrm{Cl}_{2}\left(\mathrm{O}_{2} \mathrm{CCH}_{2} \mathrm{CH}\right. \\ \mathrm{NH}- & \left.{ }_{2} \mathrm{CONH}-\mathrm{SWNT}\right) \text { moiety } \\ \text { SWNT })\left(\mathrm{O}_{2} \mathrm{CCH}_{2} \mathrm{CH}_{2} \mathrm{CONH}-\right. & \text { is coupled to the folate }\end{array}$

PEG-folate)]
None: folate coupled
directly to the
nanoparticles via a PEG spacer

tumour cells

$\left[\mathrm{Pt}\left(\mathrm{NH}_{3}\right)_{2}\left(\mathrm{H}_{2} \mathrm{O}\right)_{2}\right]^{2+}$

Preferential uptake in FR+ve HeLa cells compared to FR-ve L929 cells

Cisplatin

Preferential uptake in $\mathrm{FR}+\mathrm{ve} \mathrm{KB}$ and

JAR cells compared

to FR-ve NTera-2

cells
Superior

cytotoxicity

compared to non-

targeted Cisplatin in

A2780 cells

A2780

xenografted mice:

Superior

cytotoxicity

compared to non-

targeted Cisplatin

4-fold and 1-fold

more active against

FR+ve HeLa and

FR-ve L929

,compared to

$\left[\mathrm{Pt}\left(\mathrm{NH}_{3}\right)_{2}\left(\mathrm{H}_{2} \mathrm{O}\right)_{2}\right]^{2+}$

8.6-fold increase in

activity against $\mathrm{KB}$

cells compared to

cisplatin.

Table 3: The structural and biological profiles for FR targeted non-platinum anticancer conjugates.

\section{FR Targeted Non-Platinum Anticancer Conjugates}

\begin{tabular}{|c|c|c|c|c|c|c|}
\hline Conjugate type & Linker & Active Component & $\begin{array}{l}\text { Cellular Uptake } \\
\text { studies }\end{array}$ & In-Vitro Activity & In-Vivo Activity & Ref. \\
\hline$\gamma$-Folate-PEG-Ga(HDOTA) & polyethyleneglycol & Ga(HDOTA) & None reported & $\begin{array}{l}\gamma \text {-Folate-PEG- } \\
\text { Ga(HDOTA) is } 2 \text { - } \\
\text { fold and } 10 \text {-fold }\end{array}$ & None reported & [196] \\
\hline
\end{tabular}


Folate-HSA-

\section{$[\mathrm{Cu}(\mathrm{PLN})(\text { phen })]^{+}$}

(HSA = human serum albumin; PLN = plumbagin; phen $=1,10$ phenanthroline).

\section{ZnaPc-folate \\ $(\mathrm{aPc}=$ tetraaminophthalocyanine}

None: folate coupled directly to the tetraaminophthalocyanin

\section{$[\mathrm{Cu}(\mathrm{PLN})(\text { phen })]^{+} \quad$ None reported}

less cytotoxic than

metal-free $\gamma$-Folate-

PEG-(HDOTA) in

$\mathrm{FR}+$ ve A2780/Ad

and FR-ve CHO.

Folate-HSA-

$[\mathrm{Cu}(\mathrm{PLN})(\text { phen })]^{+}$

None reported

approximately 3

times more active

against the FR+ve

Hela and MCF-7

cells than the FR-ve

WI-38 cell line.

10-fold decrease in

cell viability

compared to results

for sulphonated

by confoc

scanning

microscopy in

competitive binding

studies using folic

acid involving

$\mathrm{FR}+$ ve $\mathrm{KB}$ and FR-

ve A549 cells
None reported aluminium

phthalocyanine

(AlPcS), an

approved

photosensitizer for

clinical applications

under common one-

photon excitation of

red light 
Table 4: The structural and biological profiles for folate-metal complex conjugates with targeted diagnostic potential.

\begin{tabular}{|c|c|c|c|c|c|c|}
\hline \multicolumn{7}{|c|}{ FR Targeted metal complexes as diagnostic agents } \\
\hline Conjugate type & Linker & $\begin{array}{l}\text { Active } \\
\text { Component }\end{array}$ & $\begin{array}{l}\text { Cellular Uptake } \\
\text { studies }\end{array}$ & In-Vitro Activity & In-Vivo Activity & Ref. \\
\hline $\begin{array}{l}\left.\text { [FA-(phen)Eu(BTA })_{3}\right](\text { FA- }(\text { phen })= \\
\text { Folate-spcer-1,10-phenanthroline } \\
\text { conjugate; BTA = benzoyl } \\
\text { trifluoroacetone })\end{array}$ & ethylenediamine & $\begin{array}{l}{[\text { FA- }} \\
\left.\text { (phen)Eu(BTA })_{3}\right]\end{array}$ & $\begin{array}{l}\text { Luminescence } \\
\text { measurements in } \\
\text { FR+ve HeLa cells } \\
\text { and competitive } \\
\text { binding studies } \\
\text { with Folic acid }\end{array}$ & None reported & None reported & {$[207]$} \\
\hline $\begin{array}{l}\mathrm{Eu}^{3+} \mathrm{C} 1, \mathrm{Eu}^{3+} \mathrm{C} 2, \mathrm{Eu}^{3+} \mathrm{C} 3 \text {, (europium } \\
\text { complexes conjugated via } 1,4,7,10- \\
\text { Tetraazacyclododecane-1,4,7,10- } \\
\text { tetraacetic acid (DOTA) to } \alpha- \\
\text { carboxylate, the } \gamma \text {-carboxylate and } \\
\text { N10 positions of folic acid, } \\
\text { respectively }\end{array}$ & $\begin{array}{l}\text { Tetraazacyclododecane- } \\
1,4,7,10 \text {-tetraacetic acid } \\
\text { (DOTA) }\end{array}$ & & $\begin{array}{l}\text { Uptake in FR+ve } \\
\text { SKOV-3 cells was } \\
\text { conjugation } \\
\text { dependent } \\
\left(\mathrm{Eu}^{3+} \mathrm{C} 2>\mathrm{Eu}^{3+} \mathrm{C} 1>\right. \\
\left.\mathrm{Eu}^{3+} \mathrm{C} 3\right) \text { with no } \\
\text { uptake in FR-ve } \\
\mathrm{A} 2780 \text { cells. }\end{array}$ & $\begin{array}{l}\text { Non-toxic below } \\
300 \mu \mathrm{M}\end{array}$ & None reported & {$[212]$} \\
\hline $\begin{array}{l}\text { FA-NH- }\left(\mathrm{CH}_{2}\right)_{\mathrm{n}}-\mathrm{NH}-[\mathrm{Ln}(\mathrm{DOTA})] \\
(\mathrm{Ln}(\mathrm{III})=\mathrm{Eu}(\mathrm{III}), \mathrm{Tb}(\mathrm{III}) \text { or } \mathrm{Gd}(\mathrm{III})) ; \\
\mathrm{n}=2 \text { or } 6)\end{array}$ & $\begin{array}{l}\text { The diamine chain } \\
\text {-NH- }\left(\mathrm{CH}_{2}\right)_{\mathrm{n}}-\mathrm{NH}-\end{array}$ & {$[\operatorname{Ln}(\mathrm{DOTA})]^{3+}$} & $\begin{array}{l}\text { Effectively } \\
\text { internalised by } \\
\text { FR+ve HeLa cells } \\
\text { with the shorter } \\
\text { linker yielding } \\
\text { superior uptake }\end{array}$ & None reported & None reported & {$[215]$} \\
\hline $\begin{array}{l}\mathrm{Tb}(\mathrm{III}) \mathrm{DTPA} \text {-folate-Fe } \mathrm{O}_{4} \\
\text { nanoparticle conjugates (denoted as } \\
\text { Tb:1b-FA-NP’s)(DTPAH } \\
\text { diethylenetriaminepentaacetic acid) }\end{array}$ & $\begin{array}{l}\text { The linkers between the } \\
\text { TB;1b and NP moieties } \\
\text { are polyethyleneglycol } \\
\text { chains (PEG's) }\end{array}$ & {$[\mathrm{Tb}(\mathrm{DTPA})]^{3+}$} & $\begin{array}{l}\text { Preferential uptake } \\
\text { in FR+ve HeLa } \\
\text { over FR-ve MCF-7 } \\
\text { cells }\end{array}$ & $\begin{array}{l}\text { Non-toxic to HeLa } \\
\text { cells up to } 160 \mu \mathrm{M} \\
\text { Superparamagnetic } \\
\text { in HeLa cells with } \\
\text { effective contrast } \\
\text { enhancement in } \\
\text { MRI as well as }\end{array}$ & None reported & [218] \\
\hline
\end{tabular}




\begin{tabular}{|c|c|c|c|c|c|c|}
\hline $\begin{array}{l}\text { Heterobimetallic } \quad \text { Cu(II) } \\
\text { corrole/Gd(III) DOTA-folate } \\
\text { complex (potential dual active (MRI } \\
\text { and PET imaging) }\end{array}$ & ethylenediamine & $\begin{array}{l}{[\mathrm{Cu}(\text { corrole })]^{2+}} \\
\text { and } \\
{[\mathrm{Gd}(\mathrm{DOTA})]^{3+}}\end{array}$ & None reported & None reported & None reported & [208] \\
\hline $\begin{array}{l}{ }^{99 m} \text { Tc-EC20 (SPECT imaging } \\
\text { agent) }\end{array}$ & $\begin{array}{l}{ }^{99 \mathrm{~m}} \mathrm{Tc}(\mathrm{V}) \text { is complexed } \\
\text { to a peptide (Cys-Asp- } \\
\text { Dap-D-Glu-Pte) which } \\
\text { is linked to a folate } \\
\text { moiety via a diamine } \\
\text { group }\end{array}$ & ${ }^{99 \mathrm{~m}}$ Tc-EC20 & $\begin{array}{l}\text { Extensively } \\
\text { studied with very } \\
\text { high cellular } \\
\text { uptake in FR-ve } \\
\text { cell lines in-vitro }\end{array}$ & Low cytotoxicity & $\begin{array}{l}\text { Very high tumour } \\
\text { uptake in a mouse } \\
\text { model and in } \\
\text { clinical trials. } \\
\text { Significant FR } \\
\text { mediated renal } \\
\text { uptake. }\end{array}$ & $\begin{array}{l}{[127} \\
128 \\
223- \\
225]\end{array}$ \\
\hline $\begin{array}{l}{\left[{ }^{99 \mathrm{~m}} \mathrm{TcN}(\mathrm{PNP})\right]^{2+}-\mathrm{O}-\mathrm{S}-\text { folate }} \\
\text { conjugate }\{\mathrm{N}(\mathrm{PNP})=\mathrm{N}- \\
\text { (2methoxyethyl)-2- } \\
\text { (diphenylphosphino)-N-(2- } \\
\text { diphenylphosphino)ethyethanamine }\end{array}$ & $\begin{array}{l}\text {-O-S-folate constructed } \\
\text { by attaching a cysteine- } \\
\text { based }(\mathrm{O}-\mathrm{S}) \text { chelating } \\
\text { group to the } \gamma \text { - } \\
\text { carboxylate of folic } \\
\text { acid. }\end{array}$ & {$\left[{ }^{99 \mathrm{~m}} \mathrm{TcN}(\mathrm{PNP})\right]^{2+}$} & $\begin{array}{l}10 \text {-fold less } \\
\text { affinity for FR+ve } \\
\text { KB-31 cells than } \\
\text { folic acid }\end{array}$ & Low toxicity & $\begin{array}{l}\text { In normal Swiss } \\
\text { mice the } \\
\text { conjugate was } \\
\text { effectively } \\
\text { cleared from the } \\
\text { kidneys }\end{array}$ & [222] \\
\hline
\end{tabular}




\section{CONCLUSION}

As it stands, folate-targeted drug therapy is proving to be a rich vein of research into the diagnosis and treatment of many forms of cancer. This is emphasised by the continuous stream of literature regarding the topic published since early 2000. However, there is a dearth of published material in relation to studies conducted on folatetargeted metal-based therapies over the same time frame. From the data available, it is apparent that the subject area is in its infancy and has the potential to contribute greatly to cancer research, both in therapy and diagnosis.

Folic acid is an interesting ligand for metal complex formation, but its coordination chemistry is not well developed. Incorporating simple folate ligands into biologically active metal complex systems may offer a simple strategy for improving their selective uptake in FR+ve cells. This remains an avenue yet to be exploited with the issue of metal complex solubility presenting a significant challenge, as encountered in the work reported thus far. The very recent introduction of novel FR-selective folate-based coordination complex nanotubes [181, 182], employing very simple chemistry, and which have excellent anticancer therapeutic potential in their own right, is an exciting example of this approach. The ability to encapsulate clinical drugs such as cisplatin or doxorubicin in the inner tubes of such nanotubes further extends the scope to develop selective drug carrier systems with dual therapeutic capability, which may also lead to new mechanisms of action.

The success of the platinum drugs in treating a range of cancers is compromised by issues relating to toxic side-effects, drug resistance and the lack of tumour selectivity. Promising recent results show that incorporation of drugs such as cisplatin and carboplatin into folate- or folate-carrier- systems has the potential to overcome these problems to some extent by improving their delivery and/or selectivity. Very few non-platinum metal complex conjugates with folic acid have been reported in the literature, and the majority of studies conducted to date lack substantial in vitro and/or in vivo data. However, this is an avenue that offers significant potential to develop targeted therapeutic approaches in areas such as chemotherapy and molecular imaging for diagnostics.

If this approach is to be fully exploited there are experimental challenges to overcome. The synthesis, purification and characterisation of metal complex-folate (and/or folate-carrier-) conjugates are quite often difficult, presenting problems in relation to biomedical applications. Furthermore, the expression levels of the folate receptor in different cell types has been a topic of significant interest with data in the literature being somewhat confusing, a situation that requires caution when assaying the selectivity of potentially active compounds. For example the breast cancer cell line MCF-7 has been reported to express normal levels of folate receptor in one study[226], while more recently it has been reported to overexpress the receptor.[227] Indeed, some authors have even reported the use of the MCF-7 cell line as negative controls for folate receptor.[226, 228-230] Similarly, in 2012 the folate receptor expression was reported to be high in the well characterized cervical cancer cell line HeLa,[231] and low in a paper published in 2013.[232] 
Notwithstanding these challenges, where over-expression of the folate receptor is well documented and a key cellular feature of diseases such as cancer, inflammation, tuberculosis and parasitic infection, the coupling of the biologically active inorganic complexes with folate receptor targeted capability is a highly desirable goal, offering the opportunity to avoid unwanted side-effects during diagnosis and treatment.

\section{LIST OF ABBREVIATIONS}

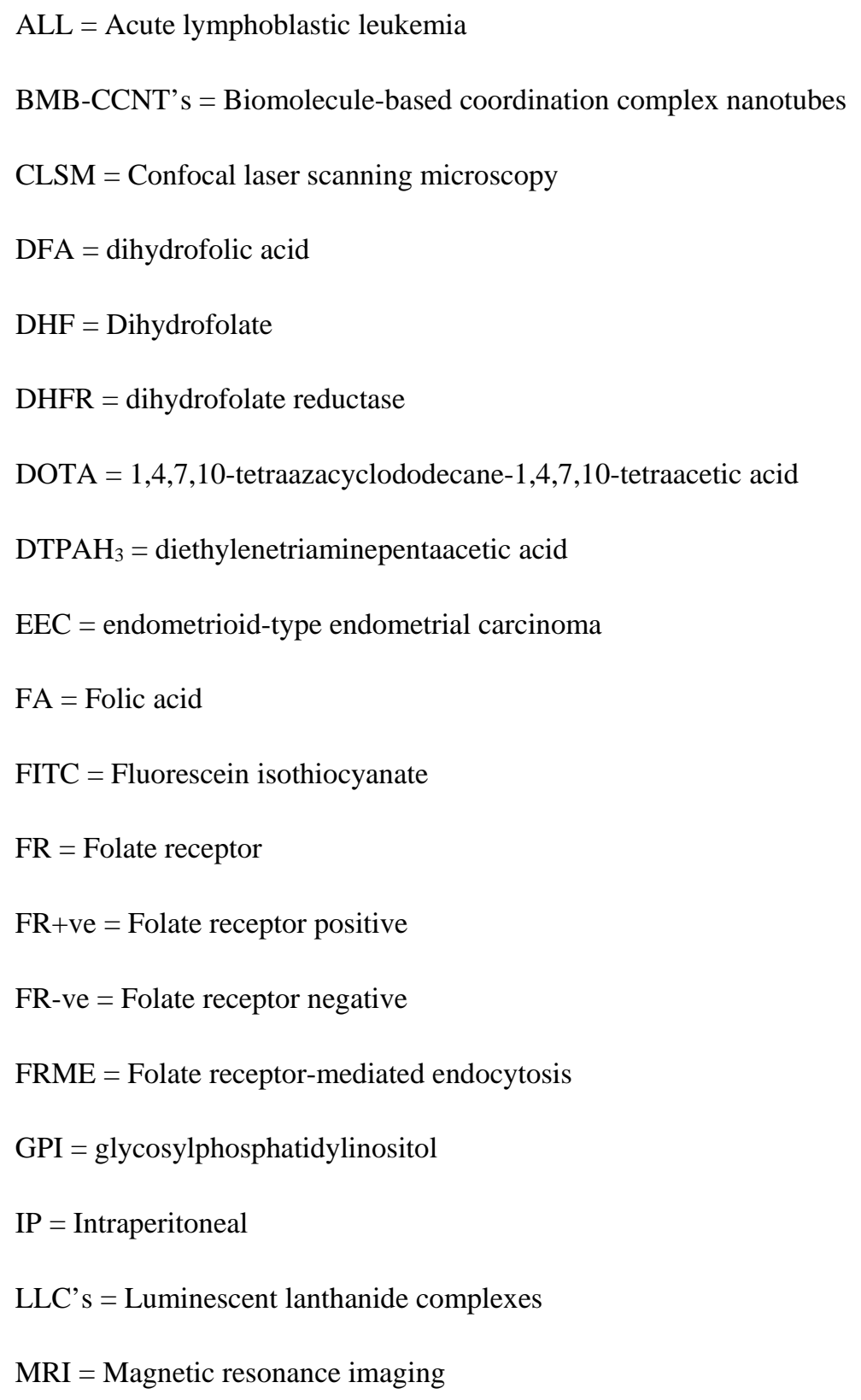


MTX = Methotrexate

$\mathrm{NADPH}=$ nicotinamide adenine dinucleotide phosphate

NSCLC $=$ Non-small-cell lung cancer

PABA $=$ Para-aminobenzoic acid

PCFT $=$ Proton-coupled folate transporter

PEG = Polyethyleneglycol

PET = positron emission tomography

PFS $=$ Progression-free survival

PDT $=$ photo-dynamic therapy

RFC $=$ Reduced folate carrier

SMDC $=$ Small molecule drug conjugate

SPECT $=$ Single photon emission computed tomography

SWNT $=$ Single-walled carbon nanotube

T-DM1 $=$ Trastuzumab emtansine

THF $=$ Tetrahydrofolate

\section{CONFLICT OF INTEREST}

The authors confirm that the material and content presented in this article do not present any issues with respect to conflict of interest.

\section{ACKNOWLEDGEMENTS}

Financial support is acknowledged through the DIT Arnold F. Graves research fellowship (PMc C) and Fiosraigh PhD scholarship (AC) schemes. 


\section{REFERENCES}

[1] Einhorn, J., Nitrogen mustard: the origin of chemotherapy for cancer. International Journal of Radiation Oncology Biology Physics, 1985, 11, (7), 1375-1378.

[2] Farber, S.; Cutler, E.C.; Hawkins, J.W.; Harrison, J.H.; Peirce, E.C.; Lenz, G.G., The Action of Pteroylglutamic Conjugates on Man. Science, 1947, 106, (2764), 619-621.

[3] Farber , S.; Diamond , L.K.; Mercer , R.D.; Sylvester , R.F.J.; Wolff , J.A., Temporary Remissions in Acute Leukemia in Children Produced by Folic Acid Antagonist, 4-Aminopteroyl-Glutamic Acid (Aminopterin). New England Journal of Medicine, 1948, 238, (23), 787-793.

[4] Hoffbrand, A.V.; Weir, D.G., The history of folic acid. British Journal of Haematology, 2001, 113, (3), 579-

589.

[5] Miller, D.R., A tribute to Sidney Farber - the father of modern chemotherapy. British Journal of Haematology, 2006, 134, (1), 20-26.

[6] Rajagopalan, P.T.R.; Zhang, Z.Q.; McCourt, L.; Dwyer, M.; Benkovic, S.J.; Hammes, G.G., Interaction of dihydrofolate reductase with methotrexate: Ensemble and single-molecule kinetics. Proc. Natl. Acad. Sci. U. S. A., 2002, 99, (21), 13481-13486.

[7] Cronstein, B.N.; Bertino, J.R. Methotrexate. Birkhäuser Basel, 2012.

[8] Mauritz, R.; Peters, G.J.; Kathmann, I.; Teshale, H.; Noordhuis, P.; Comijn, E.M.; Pinedo, H.M.; Jansen, G., Dynamics of antifolate transport via the reduced folate carrier and the membrane folate receptor in murine leukaemia cells in vitro and in vivo. Cancer Chemother. Pharmacol., 2008, 62, (6), 937-948.

[9] Li, M.C.; Hertz, R.; Spencer, D.B., Effect of Methotrexate Therapy upon Choriocarcinoma and Chorioadenoma. Experimental Biology and Medicine, 1956, 93, (2), 361-366.

[10] Korkmaz, T.; Seber, S.; Basaran, G., Review of the current role of targeted therapies as maintenance therapies in first and second line treatment of epithelial ovarian cancer; In the light of completed trials. Critical Reviews in Oncology Hematology, 2016, 98, 180-188.

[11] Kummar, S.; Chen, H.X.; Wright, J.; Holbeck, S.; Millin, M.D.; Tomaszewski, J.; Zweibel, J.; Collins, J.; Doroshow, J.H., Utilizing targeted cancer therapeutic agents in combination: novel approaches and urgent requirements. Nature Reviews Drug Discovery, 2010, 9, (11), 843-856.

[12] Perez-Herrero, E.; Fernandez-Medarde, A., Advanced targeted therapies in cancer: Drug nanocarriers, the future of chemotherapy. European Journal of Pharmaceutics and Biopharmaceutics, 2015, 93, 52-79.

[13] Vanneman, M.; Dranoff, G., Combining immunotherapy and targeted therapies in cancer treatment. Nature Reviews Cancer, 2012, 12, (4), 237-251.

[14] Yap, T.A.; Carden, C.P.; Kaye, S.B., Beyond chemotherapy: targeted therapies in ovarian cancer. Nature Reviews Cancer, 2009, 9, (3), 167-181.

[15] Zwicke, G.L.; Mansoori, G.A.; Jeffery, C.J., Utilizing the folate receptor for active targeting of cancer nanotherapeutics. Nano reviews, 2012, 3.

[16] Vergote, I.; Leamon, C.P., Vintafolide: a novel targeted therapy for the treatment of folate receptor expressing tumors. Ther. Adv. Med. Oncol., 2015, 7, (4), 206-218.

[17] https://clinicaltrials.gov/ct2/show/results/NCT01170650?term=vintafolide\&rank=10.

[18] Armstrong, D.K.; White, A.J.; Weil, S.C.; Phillips, M.; Coleman, R.L., Farletuzumab (a monoclonal antibody against folate receptor alpha) in relapsed platinum-sensitive ovarian cancer. Gynecol. Oncol., 2013, 129, (3), $452-458$. [19] https://clinicaltrials.gov/ct2/show/NCT02289950.

[20] Ponte, J.F.; Ab, O.; Lanieri, L.; Lee, J.; Coccia, J.; Bartle, L.M.; Themeles, M.; Zhou, Y.H.; Pinkas, J.; RuizSoto, R., Mirvetuximab Soravtansine (IMGN853), a Folate Receptor Alpha-Targeting Antibody-Drug Conjugate, Potentiates the Activity of Standard of Care Therapeutics in Ovarian Cancer Models1. Neoplasia, 2016, 18, (12), 775784.

[21] Moore, K.N.; Martin, L.P.; O’Malley, D.M.; Matulonis, U.A.; Konner, J.A.; Perez, R.P.; Bauer, T.M.; RuizSoto, R.; Birrer, M.J., Safety and Activity of Mirvetuximab Soravtansine (IMGN853), a Folate Receptor AlphaTargeting Antibody-Drug Conjugate, in Platinum-Resistant Ovarian, Fallopian Tube, or Primary Peritoneal Cancer: A Phase I Expansion Study. J. Clin. Oncol., 2017, 35, (10), 1112-1118.

[22] Ambrosio, A.J.; Suzin, D.; Palmer, E.L.; Penson, R.T., Vintafolide (EC145) for the treatment of folatereceptor-alpha positive platinum-resistant ovarian cancer. Expert Review of Clinical Pharmacology, 2014, 7, (4), 443450. 
[23] Azais, H.; Moussaron, A.; Bach, S.K.; Bassil, A.; Betrouni, N.; Frochot, C.; Collinet, P.; Mordon, S., FR alpha: a target for prophylactic photodynamic therapy of ovarian peritoneal metastasis? Bulletin Du Cancer, 2014, 101, (12), 1109-1113.

[24] Garinchesa, P.; Campbell, I.; Saigo, P.E.; Lewis, J.L.; Old, L.J.; Rettig, W.J., Trophoblast and ovarian cancer antigen LK26. Sensitivity and specificity in immunopathology and molecular identification as a folate-binding protein. American Journal of Pathology, 1993, 142, (2), 557-567.

[25] Huang, Y.-n.; Wu, H.; Shen, X.-z., The role of folate receptors in the targeted diagnosis and treatment of carcinoma. Fudan Xuebao (Yixueban), 2012, 39, (1), 74-79.

[26] Marchetti, C.; Palaia, I.; Giorgini, M.; De Medici, C.; Iadarola, R.; Vertechy, L.; Domenici, L.; Di Donato, V.; Tomao, F.; Muzii, L.; Panici, P.B., Targeted drug delivery via folate receptors in recurrent ovarian cancer: a review. Oncotargets and Therapy, 2014, 7, 1223-1236.

[27] Necela, B.M.; Crozier, J.A.; Andorfer, C.A.; Lewis-Tuffin, L.; Kachergus, J.M.; Geiger, X.J.; Kalari, K.R.; Serie, D.J.; Sun, Z.F.; Aspita, A.M.; O'Shannessy, D.J.; Maltzman, J.D.; McCullough, A.E.; Pockaj, B.A.; Cunliffe, H.E.; Ballman, K.V.; Thompson, E.A.; Perez, E.A., Folate Receptor-alpha (FOLR1) Expression and Function in Triple Negative Tumors. PLoS One, 2015, 10, (3).

[28] Parker, N.; Turk, M.J.; Westrick, E.; Lewis, J.D.; Low, P.S.; Leamon, C.P., Folate receptor expression in carcinomas and normal tissues determined by a quantitative radioligand binding assay. Analytical Biochemistry, 2005, 338, (2), 284-293.

[29] Shi, H.; Guo, J.; Li, C.Z.; Wang, Z.H., A current review of folate receptor alpha as a potential tumor target in non-small-cell lung cancer. Drug Des. Dev. Ther., 2015, 9, 4989-4995.

[30] Vergote, I.B.; Marth, C.; Coleman, R.L., Role of the folate receptor in ovarian cancer treatment: evidence, mechanism, and clinical implications. Cancer and Metastasis Reviews, 2015, 34, (1), 41-52.

[31] Vlahov, I.R.; Leamon, C.P., Engineering Folate-Drug Conjugates to Target Cancer: From Chemistry to Clinic. Bioconjugate chemistry, 2012, 23, (7), 1357-1369.

[32] Feng, D.; Song, Y.C.; Shi, W.; Li, X.H.; Ma, H.M., Distinguishing Folate-Receptor-Positive Cells from Folate-Receptor-Negative Cells Using a Fluorescence Off-On Nanoprobe. Anal. Chem., 2013, 85, (13), 6530-6535.

[33] Kelemen, L.E., The role of folate receptor alpha in cancer development, progression and treatment: Cause, consequence or innocent bystander? International Journal of Cancer, 2006, 119, (2), 243-250.

[34] Dridi, L.; Ouameur, A.A.; Ouellette, M., High Affinity S-Adenosylmethionine Plasma Membrane Transporter of Leishmania Is a Member of the Folate Biopterin Transporter (FBT) Family. Journal of Biological Chemistry, 2010, 285, (26), 19767-19775.

[35] El Fadili, A.; Kundig, C.; Roy, G.; Ouellette, M., Inactivation of the Leishmania tarentolae pterin transporter (BT1) and reductase (PTR1) genes leads to viable parasites with changes in folate metabolism and hypersensitivity to the antifolate methotrexate. Journal of Biological Chemistry, 2004, 279, (18), 18575-18582.

[36] Eudes, A.; Kunji, E.R.S.; Noiriel, A.; Klaus, S.M.J.; Vickers, T.J.; Beverley, S.M.; Gregory, J.F.; Hanson, A.D., Identification of Transport-critical Residues in a Folate Transporter from the Folate-Biopterin Transporter (FBT) Family. Journal of Biological Chemistry, 2010, 285, (4), 2867-2875.

[37] Lemley, C.; Yan, S.F.; Dole, V.S.; Madhubala, R.; Cunningham, M.L.; Beverley, S.M.; Myler, P.J.; Stuart, K.D., The Leishmania donovani LD1 locus gene ORFG encodes a biopterin transporter (BT1). Molecular and Biochemical Parasitology, 1999, 104, (1), 93-105.

[38] Richard, D.; Kundig, C.; Ouellette, M., A new type of high affinity folic acid transporter in the protozoan parasite Leishmania and deletion of its gene in methotrexate-resistant cells. Journal of Biological Chemistry, 2002, 277, (33), 29460-29467.

[39] Richard, D.; Leprohon, P.; Drummelsmith, J.; Ouellette, M., Growth phase regulation of the main folate transporter of Leishmania infantum and its role in methotrexate resistance. Journal of Biological Chemistry, 2004, 279, (52), 54494-54501.

[40] Vickers, T.J.; Beverley, S.M. In Essays in Biochemistry: Molecular Parasitology. Docampo, R., Ed.; Portland Press Ltd: London, 2011; Vol. 51, pp 63-80.

[41] Jain, N.K.; Mishra, V.; Mehra, N.K., Targeted drug delivery to macrophages. Expert Opinion on Drug Delivery, 2013, 10, (3), 353-367.

[42] Kundig, C.; Haimeur, A.; Legare, D.; Papadopoulou, B.; Ouellette, M., Increased transport of pteridines compensates for mutations in the high affinity folate transporter and contributes to methotrexate resistance in the protozoan parasite Leishmania tarentolae. Embo Journal, 1999, 18, (9), 2342-2351. 
[43] Nogueira, E.; Gomes, A.C.; Preto, A.; Cavaco-Paulo, A., Folate-targeted nanoparticles for rheumatoid arthritis therapy. Nanomedicine, 2016, 12, (Copyright (C) 2016 U.S. National Library of Medicine.), 1113-1126.

[44] Paulos, C.M.; Turk, M.J.; Breur, G.J.; Low, P.S., Folate receptor-mediated targeting of therapeutic and imaging agents to activated macrophages in rheumatoid arthritis. Adv. Drug Delivery Rev., 2004, 56, (Copyright (C) 2016 American Chemical Society (ACS). All Rights Reserved.), 1205-1217.

[45] Piscaer, T.M.; Muller, C.; Mindt, T.L.; Lubberts, E.; Verhaar, J.A.N.; Krenning, E.P.; Schibli, R.; De, J.M.; Weinans, H., Imaging of activated macrophages in experimental osteoarthritis using folate-targeted animal singlephoton-emission computed tomography/computed tomography. Arthritis Rheum, 2011, 63, (Copyright (C) 2016 U.S. National Library of Medicine.), 1898-1907.

[46] Qi, R.; Majoros, I.; Misra, A.C.; Koch, A.E.; Campbell, P.; Marotte, H.; Bergin, I.L.; Cao, Z.; Goonewardena, S.; Morry, J.; Zhang, S.; Beer, M.; Makidon, P.; Kotlyar, A.; Thomas, T.P.; Baker, J.R., Jr., Folate receptor-targeted dendrimer-methotrexate conjugate for inflammatory arthritis. J. Biomed. Nanotechnol., 2015, 11, (Copyright (C) 2016 American Chemical Society (ACS). All Rights Reserved.), 1431-1441.

[47] Qi, R.; Majoros, I.; Misra, A.C.; Koch, A.E.; Campbell, P.; Marotte, H.; Bergin, I.L.; Cao, Z.; Goonewardena, S.; Morry, J.; Zhang, S.; Beer, M.; Makidon, P.; Kotlyar, A.; Thomas, T.P.; Baker, J.R., Jr., Folate Receptor-Targeted Dendrimer-Methotrexate Conjugate for Inflammatory Arthritis. J Biomed Nanotechnol, 2015, 11, (Copyright (C) 2016 U.S. National Library of Medicine.), 1431-1441.

[48] Shen, J.Y.; Hilgenbrink, A.R.; Xia, W.; Feng, Y.; Dimitrov, D.S.; Lockwood, M.B.; Amato, R.J.; Low, P.S., Folate receptor-beta constitutes a marker for human proinflammatory monocytes. Journal of Leukocyte Biology, 2014, 96, (4), 563-570.

[49] Varghese, B.; Vlashi, E.; Xia, W.; Ayala Lopez, W.; Paulos, C.M.; Reddy, J.; Xu, L.-C.; Low, P.S., Folate Receptor- $\beta$ in Activated Macrophages: Ligand Binding and Receptor Recycling Kinetics. Mol. Pharmaceutics, 2014, 11, (Copyright (C) 2016 American Chemical Society (ACS). All Rights Reserved.), 3609-3616.

[50] Yang, J.; Vlashi, E.; Low, P., Folate-linked drugs for the treatment of cancer and inflammatory diseases. Subcell. Biochem., 2012, 56, (Copyright (C) 2016 American Chemical Society (ACS). All Rights Reserved.), 163179.

[51] Zhao, R.B.; Matherly, L.H.; Goldman, I.D., Membrane transporters and folate homeostasis: intestinal absorption and transport into systemic compartments and tissues. Expert Reviews in Molecular Medicine, 2009, 11.

[52] Murray, R.K. Harper's Illustrated Biochemistry. Lange Medical/McGraw-Hill, 2003.

[53] Wright, J.C.; Gumport, S.L.; Golomb, F.M., Remissions produced with the use of Methotrexate in patients with mycosis fungoides. Cancer Chemother Rep, 1960, 9, 11-20.

[54] Wright, J.C.; Lyons, M.M.; Golomb, F.M.; Medrek, T.J.; Gumport, S.L.; Walker, D.G., Observations on use of cancer chemotherapeutic agents in patients with Mycosis fungoides. Cancer, 1964, 17, (8), 1045-\&.

[55] Wright, J.C.; Prigot, A.; Wright, B.; Weintraub, S.; Wright, L.T., An evaluation of folic acid antagonists in adults with neoplastic diseases: a study of 93 patients with incurable neoplasms. J Natl Med Assoc, 1951, 43, (4), 211240.

[56] Goldin, A.; Venditti, J.M.; Humphreys, S.R.; Dennis, D.; Mantel, N.; Greenhouse, S.W., A quantitative comparison of the antileukemic effectiveness of two folic acid antagonists in mice. J Natl Cancer Inst, 1955, 15, (6), 1657-1664.

[57] Cole, P.D.; Drachtman, R.A.; Smith, A.K.; Cate, S.; Larson, R.A.; Hawkins, D.S.; Holcenberg, J.; Kelly, K.; Kamen, B.A., Phase II trial of oral aminopterin for adults and children with refractory acute leukemia. Clin. Cancer Res., 2005, 11, (22), 8089-8096.

[58] Norris, R.E.; Adamson, P.C., Clinical potency of methotrexate, aminopterin, talotrexin and pemetrexed in childhood leukemias. Cancer Chemother. Pharmacol., 2010, 65, (6), 1125-1130.

[59] Kamen, B.A.; Finiewicz, K.; Holcenberg, J.S.; Larson, R.; Miller, D.S.; Muller, C.Y.; Ratliff, A.F.; Coleman, R.L., Aminopterin (AMT), an "old dog with new tricks": therapeutic and pharmacodynamic results of early phase II trials for patients with acute leukemia and endometrial cancer. Clin. Cancer Res., 1999, 5, 3773S-3773S.

[60] Ratliff, A.F.; Wilson, J.; Hum, M.; Marling-Cason, M.; Rose, K.; Winick, N.; Kamen, B.A., Phase I and pharmacokinetic trial of aminopterin in patients with refractory malignancies. J. Clin. Oncol., 1998, 16, (4), 14581464.

[61] Visentin, M.; Zhao, R.B.; Goldman, I.D., The Antifolates. Hematology-Oncology Clinics of North America, 2012, 26, (3), 629-+.

[62] Zhao, R.B.; Goldman, I.D., Resistance to antifolates. Oncogene, 2003, 22, (47), 7431-7457. 
[63] 24/08/2016, N.C.I.F.A.f.P.D.h.w.c.g.a.-c.t.d.f.-p.-d.m.p.A.o.t.

[64] Cohen, M.H.; Justice, R.; Pazdur, R., Approval Summary: Pemetrexed in the Initial Treatment of Advanced/Metastatic Non-Small Cell Lung Cancer. Oncologist, 2009, 14, (9), 930-935.

[65] Manegold, C., Pemetrexed (alimta, MTA, multitargeted antifolate, LY231514) for malignant pleural mesothelioma. Seminars in Oncology, 30, 32-36.

[66] Rossi, A.; Ricciardi, S.; Maione, P.; de Marinis, F.; Gridelli, C., Pemetrexed in the treatment of advanced non-squamous lung cancer. Lung Cancer, 66, (2), 141-149.

[67] Rosowsky, A.; Wright, J.E.; Vaidya, C.M.; Forsch, R.A., The effect of side-chain, para-aminobenzoyl region, and B-ring modifications on dihydrofolate reductase binding, influx via the reduced folate carrier, and cytotoxicity of the potent nonpolyglutamatable antifolate $\mathrm{N}$-alpha-(4-amino-4-deoxypteroyl)-N-delta-hemiphthaloyl-L-ornithine. Pharmacology \& Therapeutics, 2000, 85, (3), 191-205.

[68] Wright, J.E.; Vaidya, C.M.; Chen, Y.N.; Rosowsky, A., Efficient utilization of the reduced folate carrier in CCRF-CEM human leukemic lymphoblasts by the potent antifolate $\mathrm{N}$-alpha-(4-amino-4-deoxypteroyl)-N-deltahemiphthaloyl-L-ornithine (PT523) and its B-ring analogues. Biochemical Pharmacology, 2000, 60, (1), 41-46.

[69] Zhao, J.; Cao, S.-L.; Zheng, X.-L.; Zhao, B., Folate receptor-mediated antitumor drugs. Yao хие хие bao = Acta pharmaceutica Sinica, 2009, 44, (2), 109-114.

[70] Roberts, J.D.; Poplin, E.A.; Tombes, M.B.; Kyle, B.; Spicer, D.V.; Grant, S.; Synold, T.; Moran, R., Weekly lometrexol with daily oral folic acid is appropriate for phase II evaluation. Cancer Chemother Pharmacol, 2000, 45, (2), 103-110.

[71] Gibbs, D.D.; Theti, D.S.; Wood, N.; Green, M.; Raynaud, F.; Valenti, M.; Forster, M.D.; Mitchell, F.; Bavetsias, V.; Henderson, E.; Jackman, A.L., BGC 945, a novel tumor-selective thymidylate synthase inhibitor targeted to alpha-folate receptor-overexpressing tumors. Cancer Res., 2005, 65, (24), 11721-11728.

[72]

[73] Zhao, R.; Goldman, I.D., Folate and Thiamine Transporters mediated by Facilitative Carriers (SLC19A1-3 and SLC46A1) and Folate Receptors. Molecular aspects of medicine, 2013, 34, (0), 10.1016/j.mam.2012.1007.1006.

[74] Spector, R.; Johanson, C., Micronutrient and urate transport in choroid plexus and kidney: implications for drug therapy. Pharm Res, 2006, 23, (11), 2515-2524.

[75] Matherly, L.H.; Hou, Z.; Deng, Y., Human reduced folate carrier: translation of basic biology to cancer etiology and therapy. Cancer and Metastasis Reviews, 2007, 26, (1), 111-128.

[76] Matherly, L.H.; Hou, Z.J. In Folic Acid and Folates. Litwack, G., Ed.; Elsevier Academic Press Inc: San Diego, 2008; Vol. 79, pp 145-184.

[77] Sweiry, J.H.; Yudilevich, D.L., Transport of folates at maternal and fetal sides of the placenta: lack of inhibition by methotrexate. Biochimica et biophysica acta, 1985, 821, (3), 497-501.

[78] Salazar, M.D.A.; Ratnam, M., The folate receptor: What does it promise in tissue-targeted therapeutics? Cancer and Metastasis Reviews, 2007, 26, (1), 141-152.

[79] Elnakat, H.; Ratnam, M., Distribution, functionality and gene regulation of folate receptor isoforms: implications in targeted therapy. Advanced Drug Delivery Reviews, 2004, 56, (8), 1067-1084.

[80] Chen, C.; Ke, J.Y.; Zhou, X.E.; Yi, W.; Brunzelle, J.S.; Li, J.; Yong, E.L.; Xu, H.E.; Melcher, K., Structural basis for molecular recognition of folic acid by folate receptors. Nature, 2013, 500, (7463), 486-+.

[81] Stallivieri, A.; Baros, F.; Jetpisbayeva, G.; Myrzakhmetov, B.; Frochot, C., The Interest of Folic Acid in Targeted Photodynamic Therapy. Current Medicinal Chemistry, 2015, 22, (27), 3185-3207.

[82] Toffoli, G.; Cernigoi, C.; Russo, A.; Gallo, A.; Bagnoli, M.; Boiocchi, M., Overexpression of folate binding protein in ovarian cancers. International Journal of Cancer, 1997, 74, (2), 193-198.

[83] Kalli, K.R.; Oberg, A.L.; Keeney, G.L.; Christianson, T.J.H.; Low, P.S.; Knutson, K.L.; Hartmann, L.C., Folate receptor alpha as a tumor target in epithelial ovarian cancer. Gynecol. Oncol., 2008, 108, (3), 619-626.

[84] Basal, E.; Eghbali-Fatourechi, G.Z.; Kalli, K.R.; Hartmann, L.C.; Goodman, K.M.; Goode, E.L.; Kamen, B.A.; Low, P.S.; Knutson, K.L., Functional Folate Receptor Alpha Is Elevated in the Blood of Ovarian Cancer Patients. PLoS One, 2009, 4, (7), 7.

[85] D'Angelica, M.; Ammori, J.; Gonen, M.; Klimstra, D.S.; Low, P.S.; Murphy, L.; Weiser, M.R.; Paty, P.B.; Fong, Y.M.; DeMatteo, R.P.; Allen, P.; Jarnagin, W.R.; Shia, J., Folate receptor-alpha expression in resectable hepatic colorectal cancer metastases: patterns and significance. Mod. Pathol., 2011, 24, (9), 1221-1228.

[86] Siegel, R.L.; Miller, K.D.; Jemal, A., Cancer Statistics, 2017. CA-Cancer J. Clin., 2017, 67, (1), 7-30.

[87] http://www.who.int/mediacentre/factsheets/fs297/en/. 
[88] Leamon, C.P.; Reddy, J.A., Folate-targeted chemotherapy. Advanced Drug Delivery Reviews, 2004, 56, (8), 1127-1141.

[89] Maldonado-Baez, L.; Williamson, C.; Donaldson, J.G., Clathrin-independent endocytosis: A cargo-centric view. Experimental Cell Research, 2013, 319, (18), 2759-2769.

[90] Ritter, T.E.; Fajardo, O.; Matsue, H.; Anderson, R.G.W.; Lacey, S.W., Folate receptors targeted to clathrincoated pits cannot regulate vitamin uptake. Proc. Natl. Acad. Sci. U. S. A., 1995, 92, (9), 3824-3828.

[91] Rothberg, K.G.; Ying, Y.S.; Kolhouse, J.F.; Kamen, B.A.; Anderson, R.G.W., The glycophospholipid-linked folate receptor internalizes folate without entering the clathrin-coated pit endocytic pathway. Journal of Cell Biology, 1990, 110, (3), 637-649.

[92] Sabharanjak, S.; Mayor, S., Folate receptor endocytosis and trafficking. Advanced Drug Delivery Reviews, 2004, 56, (8), 1099-1109.

[93] Wibowo, A.S.; Singh, M.; Reeder, K.M.; Carter, J.J.; Kovach, A.R.; Meng, W.Y.; Ratnam, M.; Zhang, F.M.; Dann, C.E., Structures of human folate receptors reveal biological trafficking states and diversity in folate and antifolate recognition. Proc. Natl. Acad. Sci. U. S. A., 2013, 110, (38), 15180-15188.

[94] Paulos, C.M.; Reddy, J.A.; Leamon, C.P.; Turk, M.J.; Low, P.S., Ligand binding and kinetics of folate receptor recycling in vivo: Impact on receptor-mediated drug delivery. Molecular Pharmacology, 2004, 66, (6), 14061414.

[95] Wang, X.; Li, J.; Wang, Y.Q.; Cho, K.J.; Kim, G.; Gjyrezi, A.; Koenig, L.; Giannakakou, P.; Shin, H.J.C.; Tighiouart, M.; Nie, S.M.; Chen, Z.; Shin, D.M., HFT-T, a Targeting Nanoparticle, Enhances Specific Delivery of Paclitaxel to Folate Receptor-Positive Tumors. ACS Nano, 2009, 3, (10), 3165-3174.

[96] Wang, Y.; Wang, Y.Q.; Xiang, J.N.; Yao, K.T., Target-Specific Cellular Uptake of Taxol-Loaded HeparinPEG-Folate Nanoparticles. Biomacromolecules, 2010, 11, (12), 3531-3538.

[97] Yoo, H.S.; Park, T.G., Folate-receptor-targeted delivery of doxorubicin nano-aggregates stabilized by doxorubicin-PEG-folate conjugate. J. Control. Release, 2004, 100, (2), 247-256.

[98] Low, P.S.; Henne, W.A.; Doorneweerd, D.D., Discovery and development of folic-acid-based receptor targeting for imaging and therapy of cancer and inflammatory diseases. Acc Chem Res, 2008, 41, (1), 120-129.

[99] Bharti, C.; Nagaich, U.; Pal, A.K.; Gulati, N., Mesoporous silica nanoparticles in target drug delivery system: A review. International Journal of Pharmaceutical Investigation, 2015, 5, (3), 124-133.

[100] Luo, Z.; Ding, X.W.; Hu, Y.; Wu, S.J.; Xiang, Y.; Zeng, Y.F.; Zhang, B.L.; Yan, H.; Zhang, H.C.; Zhu, L.L.; Liu, J.J.; Li, J.H.; Cai, K.Y.; Zhao, Y.L., Engineering a Hollow Nanocontainer Platform with Multifunctional Molecular Machines for Tumor-Targeted Therapy in Vitro and in Vivo. ACS Nano, 2013, 7, (11), 10271-10284.

[101] Rosenholm, J.M.; Meinander, A.; Peuhu, E.; Niemi, R.; Eriksson, J.E.; Sahlgren, C.; Linden, M., Targeting of Porous Hybrid Silica Nanoparticles to Cancer Cells. ACS Nano, 2009, 3, (1), 197-206.

[102] Zhang, Q.; Liu, F.; Nguyen, K.T.; Ma, X.; Wang, X.J.; Xing, B.G.; Zhao, Y.L., Multifunctional Mesoporous Silica Nanoparticles for Cancer-Targeted and Controlled Drug Delivery. Adv. Funct. Mater., 2012, 22, (24), 51445156.

[103] Zhang, Q.; Wang, X.L.; Li, P.Z.; Nguyen, K.T.; Wang, X.J.; Luo, Z.; Zhang, H.C.; Tan, N.S.; Zhao, Y.L., Biocompatible, Uniform, and Redispersible Mesoporous Silica Nanoparticles for Cancer- Targeted Drug Delivery In Vivo. Adv. Funct. Mater., 2014, 24, (17), 2450-2461.

[104] Liang, Z.S.; Li, X.G.; Xie, Y.G.; Liu, S.Y., 'Smart' gold nanoshells for combined cancer chemotherapy and hyperthermia. Biomed. Mater., 2014, 9, (2), 11.

[105] Mansoori, G.A.; Brandenburg, K.S.; Shakeri-Zadeh, A., A Comparative Study of Two Folate-Conjugated Gold Nanoparticles for Cancer Nanotechnology Applications. Cancers, 2010, 2, (4), 1911-1928.

[106] Pedrosa, P.; Vinhas, R.; Fernandes, A.; Baptista, P.V., Gold Nanotheranostics: Proof-of-Concept or Clinical Tool? Nanomaterials, 2015, 5, (4), 1853-1879.

[107] Samadian, H.; Hosseini-Nami, S.; Kamrava, S.K.; Ghaznavi, H.; Shakeri-Zadeh, A., Folate-conjugated gold nanoparticle as a new nanoplatform for targeted cancer therapy. Journal of cancer research and clinical oncology, 2016, 142, (11), 2217-2229.

[108] Geraldo, D.A.; Duran-Lara, E.F.; Aguayo, D.; Cachau, R.E.; Tapia, J.; Esparza, R.; Yacaman, M.J.; Gonzalez-Nilo, F.D.; Santos, L.S., Supramolecular complexes of quantum dots and a polyamidoamine (PAMAM)folate derivative for molecular imaging of cancer cells. Anal. Bioanal. Chem., 2011, 400, (2), 483-492.

[109] Lu, M.; Zhang, W.D.; Gai, Y.K.; Yang, T.; Ye, P.; Yang, G.; Ma, X.; Xiang, G.Y., Folate-PEG functionalized silica CdTe quantum dots as fluorescent probes for cancer cell imaging. New J. Chem., 2014, 38, (9), 4519-4526. 
[110] Ranjbar-Navazi, Z.; Eskandani, M.; Johari-Ahar, M.; Nemati, A.; Akbari, H.; Davaran, S.; Omidi, Y., Doxorubicin-conjugated D-glucosamine- and folate- bi-functionalised InP/ZnS quantum dots for cancer cells imaging and therapy. Journal of drug targeting, 2017, 1-11.

[111] Zhang, Y.; Liu, J.M.; Yan, X.P., Self-Assembly of Folate onto Polyethyleneimine-Coated CdS/ZnS Quantum Dots for Targeted Turn-On Fluorescence Imaging of Folate Receptor Overexpressed Cancer Cells. Anal. Chem., 2013, 85, (1), 228-234.

[112] Barar, J.; Kafil, V.; Majd, M.H.; Barzegari, A.; Khani, S.; Johari-Ahar, M.; Asgari, D.; Cokous, G.; Omidi, Y., Multifunctional mitoxantrone-conjugated magnetic nanosystem for targeted therapy of folate receptoroverexpressing malignant cells. J. Nanobiotechnol., 2015, 13, 16.

[113] Li, H.; Yan, K.; Shang, Y.L.; Shrestha, L.; Liao, R.F.; Liu, F.; Li, P.H.; Xu, H.B.; Xu, Z.S.; Chu, P.K., Folatebovine serum albumin functionalized polymeric micelles loaded with superparamagnetic iron oxide nanoparticles for tumor targeting and magnetic resonance imaging. Acta Biomater., 2015, 15, 117-126.

[114] Licciardi, M.; Scialabba, C.; Cavallaro, G.; Sangregorio, C.; Fantechi, E.; Giammona, G., Cell Uptake Enhancement of Folate Targeted Polymer Coated Magnetic Nanoparticles. J. Biomed. Nanotechnol., 2013, 9, (6), 949964.

[115] Majd, M.H.; Asgari, D.; Barar, J.; Valizadeh, H.; Kafil, V.; Abadpour, A.; Moumivand, E.; Mojarrad, J.S.; Rashidi, M.R.; Coukos, G.; Omidi, Y., Tamoxifen loaded folic acid armed PEGylated magnetic nanoparticles for targeted imaging and therapy of cancer. Colloid Surf. B-Biointerfaces, 2013, 106, 117-125.

[116] Majd, M.H.; Asgari, D.; Barar, J.; Valizadeh, H.; Kafil, V.; Coukos, G.; Omidi, Y., Specific targeting of cancer cells by multifunctional mitoxantrone-conjugated magnetic nanoparticles. Journal of drug targeting, 2013, 21, (4), 328-340.

[117] Shen, J.M.; Guan, X.M.; Liu, X.Y.; Lan, J.F.; Cheng, T.; Zhang, H.X., Luminescent/Magnetic Hybrid Nanoparticles with Folate-Conjugated Peptide Composites for Tumor-Targeted Drug Delivery. Bioconjugate chemistry, 2012, 23, (5), 1010-1021.

[118] Sonvico, F.; Mornet, S.; Vasseur, S.; Dubernet, C.; Jaillard, D.; Degrouard, J.; Hoebeke, J.; Duguet, E.; Colombo, P.; Couvreur, P., Folate-conjugated iron oxide nanoparticles for solid tumor targeting as potential specific magnetic hyperthermia mediators: Synthesis, physicochemical characterization, and in vitro experiments. Bioconjugate chemistry, 2005, 16, (5), 1181-1188.

[119] Kamen, B.A.; Capdevila, A., Receptor-mediated folate accumulation is regulated by the cellular folate content. Proc. Natl. Acad. Sci. U. S. A., 1986, 83, (16), 5983-5987.

[120] Leamon, C.P.; Low, P.S., Delivery of macromolecules into living cells - a method that exploits folate receptor endocytosis. Proc. Natl. Acad. Sci. U. S. A., 1991, 88, (13), 5572-5576.

[121] Leamon, C.P.; Low, P.S., Cytotoxicity of momordin-folate conjugates in cultured human-cells. Journal of Biological Chemistry, 1992, 267, (35), 24966-24971.

[122] Leamon, C.P.; Low, P.S., Membrane folate-binding proteins are responsible for folate protein conjugate endocytosis into cultured-cells. Biochemical Journal, 1993, 291, 855-860.

[123] Dawson, R.M.C. Data for Biochemical Research. Clarendon Press, 1989.

[124] Poe, M., Acidic dissociation-constants of folic-acid, dihydrofolic acid, and methotrexate. Journal of Biological Chemistry, 1977, 252, (11), 3724-3728.

[125] Leamon, C.P.; DePrince, R.B.; Hendren, R.W., Folate-mediated drug delivery: Effect of alternative conjugation chemistry. Journal of drug targeting, 1999, 7, (3), 157-169.

[126] Boss, S.D.; Betzel, T.; Muller, C.; Fischer, C.R.; Haller, S.; Reber, J.; Groehn, V.; Schibli, R.; Ametamey, S.M., Comparative Studies of Three Pairs of $\alpha$ - and $\gamma$-Conjugated Folic Acid Derivatives Labeled with Fluorine-18. Bioconjugate Chem., 2016, 27, (Copyright (C) 2016 American Chemical Society (ACS). All Rights Reserved.), 7486.

[127] Fisher, R.E.; Siegel, B.A.; Edell, S.L.; Oyesiku, N.M.; Morgenstern, D.E.; Messmann, R.A.; Amato, R.J., Exploratory study of Tc-99m-EC20 imaging for identifying patients with folate receptor-positive solid tumors. J. Nucl. Med., 2008, 49, (6), 899-906.

[128] Leamon, C.P.; Parker, M.A.; Vlahov, I.R.; Xu, L.C.; Reddy, J.A.; Vetzel, M.; Douglas, N., Synthesis and biological evaluation of EC20: A new folate-derived, Tc-99m-based radiopharmaceutical. Bioconjugate chemistry, 2002, 13, (6), 1200-1210.

[129] Desmoulin, S.K.; Hou, Z.; Gangjee, A.; Matherly, L.H., The human proton-coupled folate transporter Biology and therapeutic applications to cancer. Cancer Biology \& Therapy, 2012, 13, (14), 1355-1373. 
[130] Zhao, R.B.; Goldman, I.D., The molecular identity and characterization of a Proton-Coupled Folate Transporter-PCFT; biological ramifications and impact on the activity of pemetrexed. Cancer and Metastasis Reviews, 2007, 26, (1), 129-139.

[131] Williams, D.R., Uses of Inorganic Chemistry in Medicine N.P. Farrell (ed.) Royal Society of Chemistry, Cambridge, UK, 1999; pp. 109-134. Applied Organometallic Chemistry, 2000, 14, (5), 282-282.

[132]

[133]

[134] Hussain, S.A.; Ma, Y.T.; Cullen, M.H., Management of metastatic germ cell tumors. Expert Review of Anticancer Therapy, 2008, 8, (5), 771-784.

[135] Einhorn, L.H., Treatment of testicular cancer - A new and improved model. J. Clin. Oncol., 1990, 8, (11), $1777-1781$.

[136] Oh, W.K.; Tay, M.H.; Huang, J., Is there a role for platinum chemotherapy in the treatment of patients with hormone-refractory prostate cancer? Cancer, 2007, 109, (3), 477-486.

[137] Coyle, B.; Kavanagh, K.; McCann, M.; Devereux, M.; Geraghty, M., Mode of anti-fungal activity of 1,10phenanthroline and its $\mathrm{Cu}(\mathrm{II}), \mathrm{Mn}(\mathrm{II})$ and $\mathrm{Ag}(\mathrm{I})$ complexes. Biometals, 2003, 16, (2), 321-329.

[138] Coyle, B.; McCann, M.; Kavanagh, K.; Devereux, M.; McKee, V.; Kayal, N.; Egan, D.; Deegan, C.; Finn, G.J., Synthesis, X-ray crystal structure, anti-fungal and anti-cancer activity of Ag-2(NH3)(2)(salH)(2) (salH(2)= salicylic acid). Journal of inorganic biochemistry, 2004, 98, (8), 1361-1366.

[139] Devereux, M.; D, O.S.; Kellett, A.; McCann, M.; Walsh, M.; Egan, D.; Deegan, C.; Kedziora, K.; Rosair, G.; Muller-Bunz, H., Synthesis, X-ray crystal structures and biomimetic and anticancer activities of novel copper(II)benzoate complexes incorporating 2-(4'-thiazolyl)benzimidazole (thiabendazole), 2-(2pyridyl)benzimidazole and 1,10-phenanthroline as chelating nitrogen donor ligands. Journal of inorganic biochemistry, 2007, 101, (6), 881-892.

[140] Devereux, M.; McCann, M.; Leon, V.; Geraghty, M.; McKee, V.; Wikaira, J., Synthesis and Biological Activity of Manganese (II) Complexes of Phthalic and Isophthalic Acid: X-Ray Crystal Structures of $\left[\mathrm{Mn}(\mathrm{ph})(\mathrm{Phen})_{2}\left(\mathrm{H}_{2} \mathrm{O}\right)\right] \cdot 4 \mathrm{H}_{2} \mathrm{O}$, [Mn(Phen $\left.)_{2}\left(\mathrm{H}_{2} \mathrm{O}\right)_{2}\right]_{2}(\mathrm{Isoph})_{2}(\mathrm{Phen}) \cdot 12 \mathrm{H}_{2} \mathrm{O}$ and $\left\{\left[\mathrm{Mn}(\mathrm{Isoph})(\text { bipy) }]_{4} \cdot 2.75\right.\right.$ biby $\} \mathrm{n}\left(\mathrm{phH} \mathrm{H}_{2}\right.$ = Phthalic Acid; isoph = Isophthalic Acid; phen = 1,10-Phenanthroline; bipy = 2,2-Bipyridine). Metal-Based Drugs, 2000, 7, (5), 275-288.

[141] Graf, N.; Lippard, S.J., Redox activation of metal-based prodrugs as a strategy for drug delivery. Advanced Drug Delivery Reviews, 2012, 64, (11), 993-1004.

[142] Hoffman, A.E.; De Stefano, M.; Shoen, C.; Gopinath, K.; Warner, D.F.; Cynamon, M.; Doyle, R.P., Co(II) and $\mathrm{Cu}(\mathrm{II})$ pyrophosphate complexes have selectivity and potency against Mycobacteria including Mycobacterium tuberculosis. European Journal of Medicinal Chemistry, 2013, 70, 589-593.

[143] Kellett, A.; O'Connor, M.; McCann, M.; Howe, O.; Casey, A.; McCarron, P.; Kavanagh, K.; McNamara, M.; Kennedy, S.; May, D.D.; Skell, P.S.; O'Shea, D.; Devereux, M., Water-soluble bis(1,10-phenanthroline) octanedioate $\mathrm{Cu} 2+$ and $\mathrm{Mn} 2+$ complexes with unprecedented nano and picomolar in vitro cytotoxicity: promising leads for chemotherapeutic drug development. MedChemComm, 2011, 2, (7), 579.

[144] Kellett, A.; O'Connor, M.; McCann, M.; McNamara, M.; Lynch, P.; Rosair, G.; McKee, V.; Creaven, B.; Walsh, M.; McClean, S.; Foltyn, A.; O'Shea, D.; Howe, O.; Devereux, M., Bis-phenanthroline copper(II) phthalate complexes are potent in vitro antitumour agents with 'self-activating' metallo-nuclease and DNA binding properties. Dalton transactions, 2011, 40, (5), 1024-1027.

[145] Kostova, I.; Saso, L., Advances in Research of Schiff-Base Metal Complexes as Potent Antioxidants. Current Medicinal Chemistry, 2013, 20, (36), 4609-4632.

[146] Livia, V.; Orla, H.; Pauraic, M.; Malachy, M.; Michael, D., The Antibacterial Activity of Metal Complexes Containing 1,10- phenanthroline: Potential as Alternative Therapeutics in the Era of Antibiotic Resistance. Current topics in medicinal chemistry, 2017, 17, (11), 1280-1302.

[147] Luo, Z.D.; Yu, L.L.; Yang, F.; Zhao, Z.N.; Yu, B.; Lai, H.Q.; Wong, K.H.; Ngai, S.M.; Zheng, W.J.; Chen, T.F., Ruthenium polypyridyl complexes as inducer of ROS-mediated apoptosis in cancer cells by targeting thioredoxin reductase. Metallomics, 2014, 6, (8), 1480-1490.

[148] McCann, M.; Geraghty, M.; Devereux, M.; O'Shea, D.; Mason, J.; O'Sullivan, L., Insights into the mode of action of the anti-Candida activity of 1,10-phenanthroline and its metal chelates. Metal-Based Drugs, 2000, 7, (4), 185-193. 
[149] McCann, M.; Kellett, A.; Kavanagh, K.; Devereux, M.; Santos, A.L.S., Deciphering the Antimicrobial Activity of Phenanthroline Chelators. Current Medicinal Chemistry, 2012, 19, (17), 2703-2714.

[150] McCann, M.; Santos, A.L.S.; da Silva, B.A.; Romanos, M.T.V.; Pyrrho, A.S.; Devereux, M.; Kavanagh, K.; Fichtner, I.; Kellett, A., In vitro and in vivo studies into the biological activities of 1,10-phenanthroline, 1,10phenanthroline-5,6-dione and its copper(ii) and silver(i) complexes. Toxicology Research, 2012, 1, (1), 47.

[151] O'Connor, M.; Kellett, A.; McCann, M.; Rosair, G.; McNamara, M.; Howe, O.; Creaven, B.S.; McClean, S.; Kia, A.F.A.; O'Shea, D.; Devereux, M., Copper(II) Complexes of Salicylic Acid Combining Superoxide Dismutase Mimetic Properties with DNA Binding and Cleaving Capabilities Display Promising Chemotherapeutic Potential with Fast Acting in Vitro Cytotoxicity against Cisplatin Sensitive and Resistant Cancer Cell Lines. Journal of medicinal chemistry, 2012, 55, (5), 1957-1968.

[152] Oliveira, C.G.; da, S.M.P.I.; Souza, P.C.; Pavan, F.R.; Leite, C.Q.; Viana, R.B.; Batista, A.A.; Nascimento, O.R.; Deflon, V.M., Manganese(II) complexes with thiosemicarbazones as potential anti-Mycobacterium tuberculosis agents. Journal of inorganic biochemistry, 2014, 132, 21-29.

[153] Thornton, L.; Dixit, V.; Assad, L.O.N.; Ribeiro, T.P.; Queiroz, D.D.; Kellett, A.; Casey, A.; Colleran, J.; Pereira, M.D.; Rochford, G.; McCann, M.; O'Shea, D.; Dempsey, R.; McClean, S.; Kia, A.F.A.; Walsh, M.; Creaven, B.; Howe, O.; Devereux, M., Water-soluble and photo-stable silver(I) dicarboxylate complexes containing 1,10phenanthroline ligands: Antimicrobial and anticancer chemotherapeutic potential, DNA interactions and antioxidant activity. Journal of inorganic biochemistry, 2016, 159, 120-132.

[154] Viganor, L.; Skerry, C.; McCann, M.; Devereux, M., Tuberculosis: An Inorganic Medicinal Chemistry Perspective. Current Medicinal Chemistry, 2015, 22, (18), 2199-2224.

[155] Dwyer, F.P.; Mayhew, E.; Roe, E.M.F.; Shulman, A., Inhibition of Landschutz Ascites Tumour growth by Metal Chelates derived from 3,4,7,8-tetramethyl-1,10-phenanthroline. British Journal of Cancer, 1965, 19, (1), 195$\&$.

[156] Dwyer, F.P.; Reid, I.K.; Shulman, A.; Laycock, G.M.; Dixson, S., Biological actions of 1,10-phenanthroline and 2,2'-bipyridine hydrochlorides quaternary salts and metal chelates and related compounds.1. Bacteriostatic action on selected gram-positive gram-negative and acid-fast bacteria. Australian Journal of Experimental Biology and Medical Science, 1969, 47, 203-\&.

[157] Kilah, N.L.; Meggers, E., Sixty Years Young: The Diverse Biological Activities of Metal Polypyridyl Complexes Pioneered by Francis P. Dwyer. Australian Journal of Chemistry, 2012, 65, (9), 1325-1332.

[158] Hambley, T.W., Developing new metal-based therapeutics: challenges and opportunities. Dalton transactions, 2007, (43), 4929-4937.

[159] Ronconi, L.; Sadler, P.J., Using coordination chemistry to design new medicines. Coordination Chemistry Reviews, 2007, 251, (13-14), 1633-1648.

[160] Anastassopoulou, J.; Theophanides, T. In Bioinorganic Chemistry: An Inorganic Perspective of Life. Kessissoglou, D.P., Ed.; Kluwer Academic Publ: Dordrecht, 1995; Vol. 459, pp 209-218.

[161] Holm, R.H.; Solomon, E.I., Bioinorganic enzymology - Preface. Chemical Reviews, 1996, 96, (7), 2237-

2237.

[162] Sadler, P.J., Inorganic Chemistry and Drug Design. Advances in Inorganic Chemistry, 1991, 36, 1-48.

[163] Nunn, J.F. Ancient Egyptian Medicine. University of Oklahoma Press, 2002.

[164] Orvig, C.; Abrams, M.J., Medicinal inorganic chemistry: Introduction. Chemical Reviews, 1999, 99, (9), 2201-2203.

[165] Lemire, J.A.; Harrison, J.J.; Turner, R.J., Antimicrobial activity of metals: mechanisms, molecular targets and applications. Nature Reviews Microbiology, 2013, 11, (6), 371-384.

[166] Kaim, W.; Schwederski, B.; Heilmann, O.; Hornung, F.M., Coordination compounds of pteridine, alloxazine and flavin ligands: structures and properties. Coordination Chemistry Reviews, 1999, 182, 323-342.

[167] Sajadi, S.A.A., Metal ion-binding properties of L-glutamic acid and L-aspartic acid, a comparative investigation. Natural Science, 2010, 02, (02), 85-90.

[168] Pfiffner, J.J.; Binkley, S.B.; Bloom, E.S.; Odell, B.L., Isolation and characterization of vitamin-Bc from liver and yeast - occurrence of an acid-labile chick antianemia factor in liver. Journal of the American Chemical Society, 1947, 69, (6), 1476-1487.

[169] El-Wahed, M.G.A.; Refat, M.S.; El-Megharbel, S.M., Synthesis, spectroscopic and thermal characterization of some transition metal complexes of folic acid. Spectrochimica Acta Part a-Molecular and Biomolecular Spectroscopy, 2008, 70, (4), 916-922. 
[170] Skorik, N.A., d-metal folates and the folic acid-imidazole conjugate. Russian Journal of Inorganic Chemistry, 2015, 60, (11), 1402-1406.

[171] Refat, M.S.; El-Megharbel, S.M.; Kobeasy, M.I.; Mahamoud, G.I.; Al-Omar, M.A.; Naglah, A.M., Synthesis, spectroscopic characterizations and biological activities of vanadyl(II) folate compound as a new anti-DNA damage and antioxidant agent. Journal of Molecular Liquids, 2016, 220, 468-477.

[172] Dametto, P.R.; Caires, F.J.; Ambrozini, B.; Ionashiro, M., Synthesis, characterization and thermal behaviour of light trivalent lanthanides folates on solid state. J. Therm. Anal. Calorim., 2011, 105, (3), 831-836.

[173] Hamed, E.; Attia, M.S.; Bassiouny, K., Synthesis, Spectroscopic and Thermal Characterization of Copper(II) and Iron(III) Complexes of Folic Acid and Their Absorption Efficiency in the Blood. Bioinorganic Chemistry and Applications, 2009.

[174] Dametto, P.R.; Ambrozini, B.; Caires, F.J.; Franzini, V.P.; Ionashiro, M., Synthesis, characterization and thermal behaviour of solid-state compounds of folates with some bivalent transition metals ions. J. Therm. Anal. Calorim., 2014, 115, (1), 161-166.

[175] Nagaj, J.; Kolkowska, P.; Bykowska, A.; Komarnicka, U.K.; Kyziol, A.; Jezowska-Bojczuk, M., Interaction of methotrexate, an anticancer agent, with copper(II) ions: coordination pattern, DNA-cleaving properties and cytotoxic studies. Medicinal Chemistry Research, 2015, 24, (1), 115-123.

[176] Xi, C.X.; Liu, Z.F.; Kong, L.; Hu, X.L.; Liu, S.P., Effects of interaction of folic acid with uranium (VI) and basic triphenylmethane dyes on resonance Rayleigh scattering spectra and their analytical applications. Analytica Chimica Acta, 2008, 613, (1), 83-90.

[177] Scrase, T.G.; Page, S.M.; Barker, P.D.; Boss, S.R., Folates are potential ligands for ruthenium compounds in vivo. Dalton transactions, 2014, 43, (22), 8158-8161.

[178] Rojo, L.; Radley-Searle, S.; Fernandez-Gutierrez, M.; Rodriguez-Lorenzo, L.M.; Abradelo, C.; Deb, S.; Roman, J.S., The synthesis and characterisation of strontium and calcium folates with potential osteogenic activity. $J$. Mat. Chem. B, 2015, 3, (13), 2708-2713.

[179] Schwederski, B.; Kaim, W., Complexes of folic acid, lumiflavin and riboflavin with bis(2, 2'bipyridine)ruthenium(II). Facilitated formation of flavosemiquinone complexes and substantial decrease of $\mathrm{pKa}(\mathrm{NH})$. Inorganica Chimica Acta, 1992, 195, (1), 123-126.

[180] Vitols, K.S.; Montejano, Y.; Duffy, T.; Pope, L.; Grundler, G.; Huennekens, F.M., Platinum-folate compounds - synthesis, properties and biological-activity. Advances in Enzyme Regulation, 1987, 26, 17-27.

[181] Liu, L.X.; Li, B.X.; Wang, Q.Y.; Dong, Z.P.; Li, H.M.; Jin, Q.M.; Hong, H.; Zhang, J.; Wang, Y., An Integrative Folate-Based Metal Complex Nanotube as a Potent Antitumor Nanomedicine as Well as an Efficient Tumor-Targeted Drug Carrier. Bioconjugate chemistry, 2016, 27, (12), 2863-2873.

[182] Wang, Y.; Zhang, C.; Li, H.M.; Zhu, G.X.; Bao, S.S.; Wei, S.Q.; Zheng, L.M.; Ren, M.; Xu, Z., Synthesis, characterization and in vitro anticancer activity of the biomolecule-based coordination complex nanotubes. J. Mat. Chem. B, 2015, 3, (2), 296-305.

[183] Butler, J.S.; Sadler, P.J., Targeted delivery of platinum-based anticancer complexes. Current Opinion in Chemical Biology, 2013, 17, (2), 175-188.

[184] Cheng, Q.; Liu, Y., Multifunctional platinum-based nanoparticles for biomedical applications. Wiley Interdisciplinary Reviews: Nanomedicine and Nanobiotechnology, 2017, 9, (2), e1410-n/a.

[185] Johnstone, T.C.; Suntharalingam, K.; Lippard, S.J., The Next Generation of Platinum Drugs: Targeted Pt(II) Agents, Nanoparticle Delivery, and Pt(IV) Prodrugs. Chemical Reviews, 2016, 116, (5), 3436-3486.

[186] Gabano, E.; Ravera, M.; Cassino, C.; Bonetti, S.; Palmisano, G.; Osella, D., Stepwise assembly of platinum - folic acid conjugates. Inorganica Chimica Acta, 2008, 361, (5), 1447-1455.

[187] Takakura, Y.; Hashida, M., Macromolecular carrier systems for targeted drug delivery: Pharmacokinetic considerations on biodistribution. Pharm. Res., 1996, 13, (6), 820-831.

[188] Aronov, O.; Horowitz, A.T.; Gabizon, A.; Gibson, D., Folate-targeted PEG as a potential carrier for carboplatin analogs. Synthesis and in vitro studies. Bioconjugate chemistry, 2003, 14, (3), 563-574.

[189] Xue, Y.K.; Tang, X.X.; Huang, J.; Zhang, X.Z.; Yu, J.H.; Zhang, Y.H.; Gui, S.B., Anti-tumor efficacy of polymer-platinum(II) complex micelles fabricated from folate conjugated PEG-graft-alpha,beta-poly (N-amino acidyl)-aspartamide and cis-dichlorodiammine platinum(II) in tumor-bearing mice. Colloid Surf. B-Biointerfaces, 2011, 85, (2), 280-288. 
[190] Dhar, S.; Liu, Z.; Thomale, J.; Dai, H.J.; Lippard, S.J., Targeted single-wall carbon nanotube-mediated Pt(IV) prodrug delivery using folate as a homing device. Journal of the American Chemical Society, 2008, 130, (34), 1146711476.

[191] Chaudhury, A.; Das, S.; Bunte, R.M.; Chiu, G.N.C., Potent therapeutic activity of folate receptor-targeted liposomal carboplatin in the localized treatment of intraperitoneally grown human ovarian tumor xenograft. International Journal of Nanomedicine, 2012, 7, 739-751.

[192] Chen, H.; Pazicni, S.; Krett, N.L.; Ahn, R.W.; Penner-Hahn, J.E.; Rosen, S.T.; O'Halloran, T.V., Coencapsulation of Arsenic- and Platinum-based Drugs for Targeted Cancer Treatment. Angewandte ChemieInternational Edition, 2009, 48, (49), 9295-9299.

[193] Nukolova, N.V.; Oberoi, H.S.; Cohen, S.M.; Kabanov, A.V.; Bronich, T.K., Folate-decorated nanogels for targeted therapy of ovarian cancer. Biomaterials, 2011, 32, (23), 5417-5426.

[194] Rout, S.R.; Behera, B.; Maiti, T.K.; Mohapatra, S., Multifunctional magnetic calcium phosphate nanoparticles for targeted platin delivery. Dalton transactions, 2012, 41, (35), 10777-10783.

[195] Ong, L.C.; Chung, F.F.L.; Tan, Y.F.; Leong, C.O., Toxicity of single-walled carbon nanotubes. Arch. Toxicol., 2016, 90, (1), 103-118.

[196] Viola-Villegas, N.; Vortherms, A.; Doyle, R.P., Targeting Gallium to Cancer Cells through the Folate Receptor. Drug Target Insights, 2008, 3, (DTI-3-Doyle-et-al), 13-25.

[197] Khoza, P.; Antunes, E.; Chen, J.Y.; Nyokong, T., Synthesis and photophysicochemical studies of a water soluble conjugate between folic acid and zinc tetraaminophthalocyanine. Journal of Luminescence, 2013, 134, 784790.

[198] Wang, S.; Wang, J.; Chen, J.Y., Conjugates of folic acids with zinc aminophthalocyanine for cancer cell targeting and photodynamic therapy by one-photon and two-photon excitations. J. Mat. Chem. B, 2014, 2, (11), 15941602.

[199] Gou, Y.; Zhang, Z.; Qi, J.X.; Liang, S.C.; Zhou, Z.P.; Yang, F.; Liang, H., Folate-functionalized human serum albumin carrier for anticancer copper(II) complexes derived from natural plumbagin. Journal of inorganic biochemistry, 2015, 153, 13-22.

[200] Checker, R.; Gambhir, L.; Sharma, D.; Kumar, M.; Sandur, S.K., Plumbagin induces apoptosis in lymphoma cells via oxidative stress mediated glutathionylation and inhibition of mitogen-activated protein kinase phosphatases (MKP1/2). Cancer Letters, 2015, 357, (1), 265-278.

[201] Padhye, S.; Dandawate, P.; Yusufi, M.; Ahmad, A.; Sarkar, F.H., Perspectives on medicinal properties of plumbagin and its analogs. Medicinal Research Reviews, 2012, 32, (6), 1131-1158.

[202] Sinha, S.; Pal, K.; Elkhanany, A.; Dutta, S.; Cao, Y.; Mondal, G.; Iyer, S.; Somasundaram, V.; Couch, F.J.; Shridhar, V.; Bhattacharya, R.; Mukhopadhyay, D.; Srinivas, P., Plumbagin inhibits tumorigenesis and angiogenesis of ovarian cancer cells in vivo. International Journal of Cancer, 2013, 132, (5), 1201-1212.

[203] Terreno, E.; Uggeri, F.; Aime, S., Image guided therapy: The advent of theranostic agents. J. Control. Release, 2012, 161, (2), 328-337.

[204] Coogan, M.P.; Fernandez-Moreira, V., Progress with, and prospects for, metal complexes in cell imaging. Chemical communications, 2014, 50, (4), 384-399.

[205] Armelao, L.; Quici, S.; Barigelletti, F.; Accorsi, G.; Bottaro, G.; Cavazzini, M.; Tondello, E., Design of luminescent lanthanide complexes: From molecules to highly efficient photo-emitting materials. Coordination Chemistry Reviews, 2010, 254, (5-6), 487-505.

[206] Butler, S.J.; Lamarque, L.; Pal, R.; Parker, D., EuroTracker dyes: highly emissive europium complexes as alternative organelle stains for live cell imaging. Chem. Sci., 2014, 5, (5), 1750-1756.

[207] Pavich, T.A.; Vorobey, A.V.; Arabei, S.M.; Solovyov, K.N., Synthesis and luminescence of a folic acideuropium chelate conjugate. Journal of Applied Spectroscopy, 2012, 79, (4), 651-655.

[208] Desbois, N.; Michelin, C.; Chang, Y.; Stupar, V.; Bonnaud, M.; Pacquelet, S.; Gros, C.P., Synthetic strategy for preparation of a folate corrole DOTA heterobimetallic Cu-Gd complex as a potential bimodal contrast agent in medical imaging. Tetrahedron Lett., 2015, 56, (51), 7128-7131.

[209] Ke, T.Y.; Feng, Y.; Guo, J.Y.; Parker, D.L.; Lu, Z.R., Biodegradable cystamine spacer facilitates the clearance of Gd(III) chelates in poly(glutamic acid) Gd-DO3A conjugates for contrast-enhanced MR imaging. Magn. Reson. Imaging, 2006, 24, (7), 931-940. 
[210] Eggenspiller, A.; Michelin, C.; Desbois, N.; Richard, P.; Barbe, J.M.; Denat, F.; Licona, C.; Gaiddon, C.; Sayeh, A.; Choquet, P.; Gros, C.P., Design of Porphyrin-dota-Like Scaffolds as All-in-One Multimodal Heterometallic Complexes for Medical Imaging. Eur. J. Org. Chem., 2013, 2013, (29), 6629-6643.

[211] Gros, C.P.; Eggenspiller, A.; Nonat, A.; Barbe, J.M.; Denat, F., New potential bimodal imaging contrast agents based on DOTA-like and porphyrin macrocycles. MedChemComm, 2011, 2, (2), 119-125.

[212] Quici, S.; Casoni, A.; Foschi, F.; Armelao, L.; Bottaro, G.; Seraglia, R.; Bolzati, C.; Salvarese, N.; Carpanese, D.; Rosato, A., Folic Acid-Conjugated Europium Complexes as Luminescent Probes for Selective Targeting of Cancer Cells. Journal of medicinal chemistry, 2015, 58, (4), 2003-2014.

[213] Bettio, A.; Honer, M.; Muller, C.; Bruhlmeier, M.; Muller, U.; Schibli, R.; Groehn, V.; Schubiger, A.P.; Ametamey, S.M., Synthesis and preclinical evaluation of a folic acid derivative labeled with 18F for PET imaging of folate receptor-positive tumors. $J$ Nucl Med, 2006, 47, (7), 1153-1160.

[214] Liu, L.W.; Yong, K.T.; Roy, I.; Law, W.C.; Ye, L.; Liu, J.W.; Liu, J.; Kumar, R.; Zhang, X.H.; Prasad, P.N., Bioconjugated Pluronic Triblock-Copolymer Micelle-Encapsulated Quantum Dots for Targeted Imaging of Cancer: In Vitro and In Vivo Studies. Theranostics, 2012, 2, (7), 705-713.

[215] Du, Z.L.; Borlace, G.N.; Brooks, R.D.; Butler, R.N.; Brooks, D.A.; Plush, S.E., Synthesis and characterisation of folic acid based lanthanide ion probes. Inorganica Chimica Acta, 2014, 410, 11-19.

[216] Park, J.A.; Kim, J.Y.; Lee, Y.J.; Lee, W.; Lim, S.M.; Kim, T.J.; Yoo, J.; Chang, Y.; Kim, K.M., Gadolinium Complex of I-125/I-127-RGD-DOTA Conjugate as a Tumor-Targeting SPECT/MR Bimodal Imaging Probe. ACS Med. Chem. Lett., 2013, 4, (2), 216-219.

[217] Ranyuk, E.; Lebel, R.; Berube-Lauziere, Y.; Klarskov, K.; Lecomte, R.; van Lier, J.E.; Guerin, B., Ga68/DOTA- and Cu-64/NOTA-Phthalocyanine Conjugates as Fluorescent/PET Bimodal Imaging Probes. Bioconjugate chemistry, 2013, 24, (9), 1624-1633.

[218] Wang, B.D.; Hai, J.; Wang, Q.; Li, T.R.; Yang, Z.Y., Coupling of Luminescent Terbium Complexes to Fe3O4 Nanoparticles for Imaging Applications. Angewandte Chemie-International Edition, 2011, 50, (13), 3063-3066.

[219] Ke, C.Y.; Mathias, C.J.; Green, M.A., The folate receptor as a molecular target for tumor-selective radionuclide delivery. Nucl. Med. Biol., 2003, 30, (8), 811-817.

[220] Ke, C.Y.; Mathias, C.J.; Green, M.A., Folate-receptor-targeted radionuclide imaging agents. Advanced Drug Delivery Reviews, 2004, 56, (8), 1143-1160.

[221] Muller, C.; Schibli, R., Folic Acid Conjugates for Nuclear Imaging of Folate Receptor-Positive Cancer. J. Nucl. Med., 2011, 52, (1), 1-4.

[222] Vats, K.; Subramanian, S.; Mathur, A.; Sarma, H.D.; Banerjee, S., Radiosynthesis and evaluation of a 99mTcfolic acid radiotracer prepared using [99mTcN(PNP)]2+ metal fragment. Bioorganic \& medicinal chemistry letters, 2017, 27, (5), 1329-1332.

[223] Muller, C.; Reddy, J.A.; Leamon, C.P.; Schibli, R., Effects of the Antifolates Pemetrexed and CB3717 on the Tissue Distribution of Tc-99m-EC20 in Xenografted and Syngeneic Tumor-Bearing Mice. Mol. Pharm., 2010, 7, (2), 597-604.

[224] Chen, Y.; Guo, H.J.; Xie, F.; Lu, J., Preparation and biological evaluation of (TcN)-Tc-99m-labeled pteroyllys derivative as a potential folate receptor imaging agent. Journal of Labelled Compounds \& Radiopharmaceuticals, 2014, 57, (1), 12-17.

[225] Lu, J.; Pang, Y.; Xie, F.; Guo, H.J.; Li, Y.; Yang, Z.; Wang, X.B., Synthesis and in vitro/in vivo evaluation of Tc-99m-labeled folate conjugates for folate receptor imaging. Nucl. Med. Biol., 2011, 38, (4), 557-565.

[226] Zhang, S.L.; Bai, H.H.; Pi, J.; Yang, P.H.; Cai, J.Y., Label-Free Quartz Crystal Microbalance with Dissipation Monitoring of Resveratrol Effect on Mechanical Changes and Folate Receptor Expression Levels of Living MCF-7 Cells: A Model for Screening of Drugs. Anal. Chem., 2015, 87, (9), 4797-4805.

[227] Chen, H.; Ahn, R.; Van den Bossche, J.; Thompson, D.H.; O'Halloran, T.V., Folate-mediated intracellular drug delivery increases the anticancer efficacy of nanoparticulate formulation of arsenic trioxide. Mol. Cancer Ther., 2009, 8, (7), 1955-1963.

[228] Al-Kattan, A.; Santran, V.; Dufour, P.; Dexpert-Ghys, J.; Drouet, C., Novel contributions on luminescent apatite-based colloids intended for medical imaging. J. Biomater. Appl., 2014, 28, (5), 697-707.

[229] Chung, K.N.; Saikawa, Y.; Paik, T.H.; Dixon, K.H.; Mulligan, T.; Cowan, K.H.; Elwood, P.C., Stable transfectants of human MCF-7 breast-cancer cells with increased levels of the human folate receptor exhibit an increased sensitivity to antifolates. J. Clin. Invest., 1993, 91, (4), 1289-1294. 
[230] Ebel, W.; Routhier, E.L.; Foley, B.; Jacob, S.; McDonough, J.M.; Patel, R.K.; Turchin, H.A.; Chao, Q.; Kline, J.B.; Old, L.J.; Phillips, M.D.; Nicolaides, N.C.; Sass, P.M.; Grasso, L., Preclinical evaluation of MORAb-003, a humanized monoclonal antibody antagonizing folate receptor-alpha. Cancer immunity, 2007, 7, 6.

[231] Groves, K.; Bao, B.; Zhang, J.; Cuneo, G.; Yared, W.; Peterson, J.D.; Rajopadhye, M., Non-invasive FMT quantification of folate receptor expression in mouse tumor xenografts with a new near-infrared fluorescent folate agent. Cancer Res., 2012, 72, 1.

[232] Bongartz, R.; Ag, D.; Seleci, M.; Walter, J.G.; Yalcinkaya, E.E.; Demirkol, D.O.; Stahl, F.; Timur, S.; Scheper, T., Folic acid-modified clay: targeted surface design for cell culture applications. J. Mat. Chem. B, 2013, 1, (4), 522-528. 